\title{
手術の換気機能および動脈血ガス 分圧におよ㴗す影響
}

日本医科大学 斉藤外科教室 （主任斉藤 淏教授）

（指尊 片 岡一朗 教授)

助手蟹江弘之

目次

緒言

I：手術による肺換気機能の変動

1) 調查症例と研究方法

2) 成結

肺活量の変動

1 秒量の教動

最大中閏呼気速度 (M.M.F.) の変動 1 秒率の変動

3) 小括

II：手術による動脈血ガス分圧ならびに $\mathrm{pH}$ の変 動

1）調查症例と研究方法

2) 成精

3) 小括

III : 実豎的気管支閉塞時（大）の動脈血ガス分压 の笠動之X線学的所見

1) 実験材料と研究方法

2) 成縝

3) 小括

IV : 胸部，腹部圧迫が肺換気機能にわよばす影辢

1) 調查症例と研究方法

2) 成績

3) 小括

$\mathrm{V}:$ 手術創の疼が肺換気機能および動脈血ガス 分圧におよばす影響

1) 調查应例之研究方法

2) 成績

3) 小括

VI : 齐藤式二重管の肺換気機能および動脈血ガス 分压におよばす影響

1）調查症例之研究方法

2) 成績

3) 小括

総括ならびに考按 結論

\section{腥言}

手術の肺換気機能におよはすす影辢については術後 肺合并症との関連において多くの研究が報告されて いる。

Churchill, Mc Neil (1925)(1) (2) 弓は初めて手術 前後の肺活量を測定して, 街後は胡換気機能の低下 するととを報告し，その後 Müller, Overholt, Pendergross(1929) ${ }^{(3)}$ らはX線写真によって上腹部 手術後には常に横隔膜高位固定が認められることを 証明し，街後低肺換気の原因であると主張した。 来 Powers (1928)(4), Scott (1929) ${ }^{(5)}$, Beecher $(1933)^{(6)}$, 河合 $(1936)^{(7)}$, 石山 $(1939)^{(8)}$, な ど多くの研究によって手術と肺活量の問題が論じら れてきた。しかし肺換気機能を肺活量についてのみ 論ずるととは，䐉活量が単に脯の解剖学的容積を表 わす数值であるため不合理であり，肺活量偟間的 要素をあわせ考慮する必要がある。近年, 呼吸生理 学の進步にともない，脏機能検查も細分化し，村林 (1963) ${ }^{(99}$ は肺機能挨查にわける換気動態の価值につ いて, 換気障害をみいだすのに最小限度必要と思わ れる動熊的検查法を検討しており，その他にも多く の研究が報告されている。10126)

これら諸検査法は外科領域における疾患で，とく に手術後当日に行なう検查法としては患者に与える 負担を大きく，てれら検査の大部分は患者の全面的 な協力がなくては不可能なととから，その実施はは なはだ困難である。(25) そこで著者は手術前後に従 来の肺活量の即定のほ加に, 最大努力珄呼気曲線を 描かせ，乙の曲線を分折し，1秒量，1秒率，最大 中間呼気速度 (M.M.F.)を調查した。

また肺機能の最終目的は動脈血のガス分圧を正常 そ維持することであるため，(10) (12) (13) (24) 動眽血の $\mathrm{Po}_{2}, \mathrm{Pco}_{2}, \mathrm{pH}$ について測定を行なった。従来, 渡辺 (1959)，加納 (1960)，松葉(1961)，らはいず れち肺切除術後の肺機能について，田中 (1954)(29)。 辺度 (1957) $)^{1301}$ は食道癌手術後の肺合併症の所究 
を，三谷 (1959) (31) は術前肺機能からみた胃切除術 後の肺合併症の検討を，永木 $(1965)^{(32)}$ は老人外科 における術前後の呼吸器わよび循環器系について, などの研究を行なっているが，外科的諸笑思におい て各手術部位別に，少後より肺機能坊復までの過程 を系統的に険索した研究は見当らない。をこで著者 は上述の肺換気機能，動脈血ガス分圧および $\mathrm{pH}$ Beckman 社製ガス分析器(33) を用いて, 術前から 衍後遂日的に測定し，その恢復するまでの経過を観 察した。

従来, 術後肺合并症とくに衍後無気肺時には動脈 血酸素飽和度の低下をきたすと云われているが， 34) 35)，著者の臨床例観察中に経験した術後無気肺 莚例では，動脈血ガス分圧には著明な変動を認めな かったととから，犬を用いて実験的に気管支を閉塞 し，無気肺発生時にわける動脈血ガス分圧と X線所 見との関連についてる検索を行なった。

手術と肺機能の問題に関しては, 古くから論ぜら れ，多くの学者は術後脑活量の減少することを述へ てきたが，手衡の肺換気機能におよばす影腤につい ては，手街そのすののはかに喠々の因子が考えられ る。即ち, 手衡後, 胸帯, 腹帯または紏創高などに よる強い圧迫や固定, 砂豪による圧迫などがあり, また，胸部手街後では胸哌運動を，腹部手術後では 腹壁渾動をできる限り制限して，手術創の疼痛を軽 減しようと努める。また消化管手術後に経鼻的に挿 入，留置する胃ソンデが低肺換気の原因となり，ひ いては術後肺合併症の原因の一つになるとする研究 すあるが31971，その成績は必ずしも一致していな W。

そこで著者は手術に附随したこれら諸処置が，手 術後の肺換気機能および動脈血ガス分圧にどの程度
の影留をおよぼすかを検索したので報告する。

I 手術による肺換気機能の变動

1. 調查症列亡研究方法

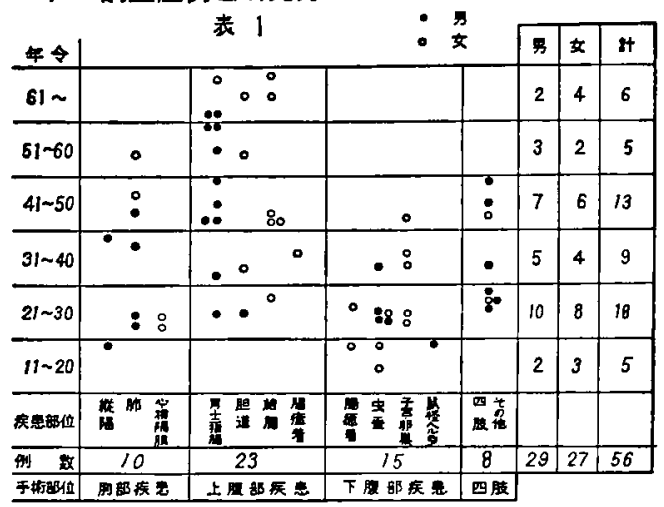

調查した症例は当外科に入院し，全身麻䣲下に手 術を行なった外科的諸疾患者より無選択的にえらん だ56例で，疾患別と年令別，性別，は表1の如くで 術前, 術後当日, 術後 2 日, 術後 4 日, 術後 7 日に 箩部X線写真をポータブル型X線㖓置を用い, 呼 気，吸気の中間期に背位で撮影し，術後肺合并症の 有無を確め, 同時期に Benedict-Roth 型レスピロ メーター $(9 \ell)$ を用いて, 肺活量, 時間肺活量 ( 1 秒量), 最大中間呼気速度 (M.M.F.)， 1 秒率 について測定した。測定にあたっては，術後当日で

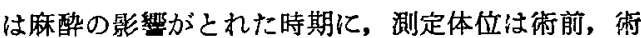
後とも背位で安静時に，各症例ともできる限り同一 条件下で行なった。測定した症例は手術部位によ り, 胸部手微, 上腹部手術, 下腹部手術, 四肢手術 その他に大別し，年令その他の因子による差違をで さるだけ消去して比較するため術前值を $100 \%$ こし て，術後の変動をそれぞれ換算して比較検討した。

(表 2)

表 $\quad 2$

\begin{tabular}{|c|c|c|c|c|c|c|c|c|c|c|c|c|}
\hline 莚 & $\begin{array}{l}\text { 氏 } \\
\text { 名 }\end{array}$ & $\begin{array}{l}\text { 性 } \\
\text { 年 }\end{array}$ & 診 & 手 術 & $\begin{array}{l}\text { 検查 } \\
\text { 日時 }\end{array}$ & V.C. & $\%$ & T.V.C. & $\%$ & 1 秒率 & M.M.F. & $\%$ \\
\hline 1 & $\begin{array}{l}\text { 佐 } \\
0 \\
\text { 正 } \\
0\end{array}$ & $\begin{array}{c}\delta \\
39\end{array}$ & 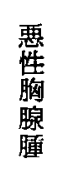 & $\begin{array}{l}\text { 肋 I 骨 } \\
\text { 骨 } \\
\text { 切II部 } \\
\text { 除III切 } \\
\text { 胸IV断 }\end{array}$ & 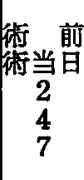 & $\begin{array}{r}2475 \\
796 \\
1188 \\
1609 \\
1906\end{array}$ & $\begin{array}{r}100 \\
29 \\
48 \\
65 \\
77\end{array}$ & $\begin{array}{r}1693 \\
491 \\
779 \\
1067 \\
1320\end{array}$ & $\begin{array}{r}100 \\
29 \\
46 \\
63 \\
78\end{array}$ & $\begin{array}{l}68.4 \\
64.0 \\
66.0 \\
66.3 \\
69.2\end{array}$ & $\begin{array}{r}1962 \\
512 \\
849 \\
1173 \\
1413\end{array}$ & $\begin{array}{r}100 \\
26 \\
43 \\
60 \\
72\end{array}$ \\
\hline 2 & $\begin{array}{l}\text { 堺 } \\
\text { 真 } \\
0\end{array}$ & $\begin{array}{c}\hat{\delta} \\
19\end{array}$ & 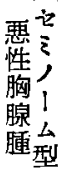 & $\begin{array}{cc}\text { 摘 } & \text { 胸 } \\
& \text { 骨 } \\
& \text { 切 } \\
& \text { 出 開 }\end{array}$ & $\begin{array}{c}\text { 秀 } \\
\text { 前前当日 } \\
2 \\
4 \\
7\end{array}$ & $\begin{array}{r}3100 \\
775 \\
1364 \\
2108 \\
2356\end{array}$ & $\begin{array}{r}100 \\
25 \\
44 \\
68 \\
76\end{array}$ & $\begin{array}{r}2550 \\
536 \\
1020 \\
1658 \\
1862\end{array}$ & $\begin{array}{r}100 \\
21 \\
40 \\
65 \\
73\end{array}$ & $\begin{array}{l}82 . \\
69 . \\
75 . \\
79 . \\
79 .\end{array}$ & $\begin{array}{r}2974 \\
578 \\
1084 \\
1725 \\
1984\end{array}$ & $\begin{array}{r}100 \\
19 \\
36 \\
58 \\
67\end{array}$ \\
\hline
\end{tabular}


第 1 号 蟹汇：手術の換気機能および動脈血ガス分圧におよぼす影響 $\quad-15$ 一

\begin{tabular}{|c|c|c|c|c|c|c|c|c|c|c|c|c|}
\hline 3 & $\begin{array}{l}\text { 原 } \\
\text { a } \\
0\end{array}$ & $\begin{array}{c}\text { 우 } \\
53\end{array}$ & 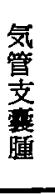 & $\begin{array}{ll}\text { 摘 } & \text { III } \\
& \text { 肋 } \\
& \text { 骨 } \\
& \text { 出 } \\
\text { 断 }\end{array}$ & 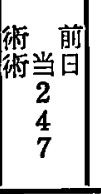 & $\begin{array}{r}1978 \\
515 \\
811 \\
1286 \\
1424\end{array}$ & $\begin{array}{r}100 \\
26 \\
41 \\
65 \\
72\end{array}$ & $\begin{array}{r}1397 \\
335 \\
545 \\
866 \\
978\end{array}$ & $\begin{array}{r}100 \\
24 \\
39 \\
62 \\
70\end{array}$ & $\begin{array}{l}71 \\
65 \\
67 \\
67 \\
69\end{array}$ & $\begin{array}{r}1662 \\
382 \\
581 \\
997 \\
1147\end{array}$ & $\begin{array}{r}100 \\
23 \\
35 \\
60 \\
69\end{array}$ \\
\hline 4 & $\begin{array}{l}\text { 畠 } \\
0 \\
才 \\
0\end{array}$ & $\begin{array}{l}\delta \\
24\end{array}$ & $"$ & $\begin{array}{ll}\text { 摘 } & \text { 而 } \\
& \text { 妿 } \\
& \text { 骲 } \\
& \text { 出 } \\
\text { 除 }\end{array}$ & 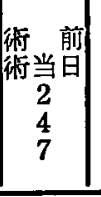 & $\begin{array}{r}3418 \\
855 \\
1538 \\
1982 \\
2290\end{array}$ & $\begin{array}{r}100 \\
25 \\
45 \\
58 \\
67\end{array}$ & $\begin{array}{r}2965 \\
682 \\
1216 \\
1700 \\
2046\end{array}$ & $\begin{array}{r}100 \\
23 \\
41 \\
57 \\
69\end{array}$ & $\begin{array}{l}87 \\
80 \\
79 \\
86 \\
89\end{array}$ & $\begin{array}{r}3587 \\
717 \\
1291 \\
1970 \\
2410\end{array}$ & $\begin{array}{r}100 \\
20 \\
36 \\
55 \\
67\end{array}$ \\
\hline 5 & $\begin{array}{l}\text { 平 } \\
0 \\
\text { 久 } \\
0\end{array}$ & $\begin{array}{l}\delta \\
37\end{array}$ & $\begin{array}{l}\text { 肺 } \\
\text { 澴 } \\
\text { 㾝 }\end{array}$ & $\begin{array}{cc}\text { 切 } & \text { 助 } \\
\text { 開 } & \text { 骨 } \\
\text { 排 } & \text { 切 } \\
\text { 膿 } & \text { 除 }\end{array}$ & 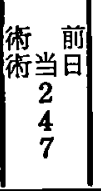 & $\begin{array}{r}1850 \\
555 \\
780 \\
944 \\
1258\end{array}$ & $\begin{array}{r}100 \\
30 \\
42 \\
51 \\
68\end{array}$ & $\begin{array}{r}1197 \\
354 \\
540 \\
722 \\
862\end{array}$ & $\begin{array}{r}100 \\
30 \\
45 \\
60 \\
72\end{array}$ & $\begin{array}{l}65 \\
64 \\
66 \\
76 \\
69\end{array}$ & $\begin{array}{r}1602 \\
433 \\
641 \\
817 \\
1073\end{array}$ & $\begin{array}{r}100 \\
27 \\
40 \\
51 \\
67\end{array}$ \\
\hline 6 & $\begin{array}{l}\text { 金 } \\
0 \\
\text { 裕 } \\
0 \\
\end{array}$ & $\begin{array}{l}\hat{\delta} \\
23\end{array}$ & $\begin{array}{l}\text { 肋 } \\
\text { 簓 } \\
\text { 䓢 } \\
\text { 澧 } \\
\text { 瑒 } \\
\end{array}$ & 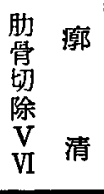 & 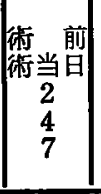 & $\begin{array}{r}2060 \\
433 \\
700 \\
1009 \\
1236\end{array}$ & $\begin{array}{r}100 \\
21 \\
34 \\
49 \\
60\end{array}$ & $\begin{array}{r}1384 \\
295 \\
512 \\
746 \\
872\end{array}$ & $\begin{array}{r}100 \\
21 \\
37 \\
54 \\
63\end{array}$ & $\begin{array}{l}67 \\
68 \\
73 \\
74 \\
71\end{array}$ & $\begin{array}{r}1972 \\
394 \\
552 \\
907 \\
1183\end{array}$ & $\begin{array}{r}100 \\
20 \\
28 \\
46 \\
60\end{array}$ \\
\hline 7 & $\begin{array}{l}\text { 山 } \\
0 \\
\text { 伝 } \\
0\end{array}$ & $\begin{array}{c}\hat{\delta} \\
43\end{array}$ & $"$ & $\begin{array}{l}\text { 肋 } \mathrm{X} \text { 淳 } \\
\text { 骨 } \mathrm{XI} \\
\text { 切XII } \\
\text { 除 } \\
\mathrm{DX} \text { 清 }\end{array}$ & \begin{tabular}{|c|} 
術 \\
前帅 \\
2 \\
4 \\
7
\end{tabular} & $\begin{array}{r}1700 \\
442 \\
595 \\
918 \\
1088\end{array}$ & $\begin{array}{r}100 \\
26 \\
35 \\
54 \\
64\end{array}$ & $\begin{array}{r}1262 \\
330 \\
454 \\
656 \\
770\end{array}$ & $\begin{array}{r}100 \\
27 \\
36 \\
52 \\
61\end{array}$ & $\begin{array}{l}74 \\
75 \\
76 \\
71 \\
71\end{array}$ & $\begin{array}{r}1190 \\
312 \\
425 \\
672 \\
782\end{array}$ & $\begin{array}{r}100 \\
24 \\
35 \\
55 \\
64\end{array}$ \\
\hline 8 & $\begin{array}{l}\text { 浅 } \\
0 \\
\text { 和 } \\
0\end{array}$ & $\begin{array}{l}\stackrel{+}{2} \\
24\end{array}$ & 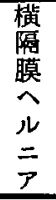 & $\begin{array}{l}\text { 根 } \\
\text { 治 } \\
\text { 手 } \\
\text { 術 }\end{array}$ & \begin{tabular}{|c|} 
衙 \\
術当前 \\
2 \\
4 \\
7
\end{tabular} & $\begin{array}{r}1755 \\
527 \\
841 \\
1332 \\
1542\end{array}$ & $\begin{array}{r}100 \\
30 \\
48 \\
76 \\
88\end{array}$ & $\begin{array}{r}1380 \\
335 \\
580 \\
980 \\
1145\end{array}$ & $\begin{array}{r}100 \\
24 \\
42 \\
71 \\
83\end{array}$ & $\begin{array}{l}71 \\
65 \\
69 \\
73 \\
74\end{array}$ & $\begin{array}{r}1964 \\
432 \\
766 \\
1316 \\
1532\end{array}$ & $\begin{array}{r}100 \\
22 \\
39 \\
67 \\
78\end{array}$ \\
\hline 9 & $\begin{array}{l}山 \\
0 \\
i \\
0\end{array}$ & $\begin{array}{c}9 \\
48\end{array}$ & 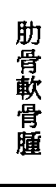 & 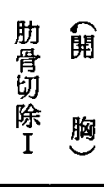 & 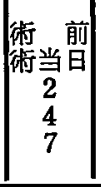 & $\begin{array}{r}2513 \\
754 \\
1030 \\
1960 \\
2136\end{array}$ & $\begin{array}{r}100 \\
30 \\
41 \\
78 \\
85\end{array}$ & $\begin{array}{r}1978 \\
554 \\
712 \\
1424 \\
1602\end{array}$ & $\begin{array}{r}100 \\
28 \\
36 \\
72 \\
81\end{array}$ & $\begin{array}{l}79 \\
73 \\
69 \\
73 \\
75\end{array}$ & $\begin{array}{r}2125 \\
556 \\
723 \\
1466 \\
1658\end{array}$ & $\begin{array}{r}100 \\
26 \\
34 \\
69 \\
79\end{array}$ \\
\hline 10 & $\begin{array}{l}\text { 石 } \\
0 \\
\nabla \\
0\end{array}$ & $\begin{array}{c}9 \\
22\end{array}$ & $\begin{array}{l}\text { 僧 } \\
\text { 算 } \\
\text { 瘗 }\end{array}$ & $\begin{array}{l}\text { 交 } \\
\text { 連 } \\
\text { 切 } \\
\text { 開 }\end{array}$ & \begin{tabular}{|c} 
庥前前 \\
当日 \\
2 \\
4 \\
7
\end{tabular} & $\begin{array}{c}2150 \\
\text { 測 定 } \\
753 \\
1290 \\
1505\end{array}$ & $\begin{array}{r}100 \\
\text { 能 } \\
35 \\
60 \\
70\end{array}$ & $\begin{array}{r}1465 \\
455 \\
820 \\
938\end{array}$ & $\begin{array}{r}100 \\
31 \\
56 \\
64\end{array}$ & $\begin{array}{l}68 \\
60 \\
64 \\
62\end{array}$ & $\begin{array}{r}2095 \\
699 \\
1173 \\
1447\end{array}$ & $\begin{array}{r}100 \\
\\
27 \\
47 \\
58\end{array}$ \\
\hline 11 & $\begin{array}{l}\text { 友 } \\
0 \\
\text { 亀 } \\
0\end{array}$ & $\begin{array}{c}f \\
68\end{array}$ & 瘭 & $\begin{array}{c}\text { 賁 } \\
\text { 除 } \\
\text { B II }\end{array}$ & 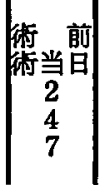 & $\begin{array}{r}1965 \\
648 \\
943 \\
1297 \\
1415\end{array}$ & $\begin{array}{r}100 \\
33 \\
48 \\
66 \\
72\end{array}$ & $\begin{array}{r}1248 \\
362 \\
562 \\
812 \\
874\end{array}$ & $\begin{array}{r}100 \\
29 \\
45 \\
65 \\
70\end{array}$ & $\begin{array}{l}64 \\
56 \\
60 \\
63 \\
62\end{array}$ & $\begin{array}{r}1965 \\
491 \\
747 \\
1100 \\
1356\end{array}$ & $\begin{array}{r}100 \\
25 \\
38 \\
56 \\
69\end{array}$ \\
\hline 12 & $\begin{array}{l}\text { 岩 } \\
0 \\
\text { 富 } \\
0\end{array}$ & $\begin{array}{c}\hat{\delta} \\
62\end{array}$ & $"$ & $\begin{array}{c}\text { 畼 } \\
\text { 除 } \\
\text { B I }\end{array}$ & \begin{tabular}{|c} 
齿前 \\
当肖日 \\
2 \\
4 \\
7
\end{tabular} & $\begin{array}{l}3240 \\
1166 \\
1555 \\
2138 \\
2430\end{array}$ & $\begin{array}{r}100 \\
36 \\
48 \\
66 \\
75\end{array}$ & $\begin{array}{r}2310 \\
740 \\
947 \\
1386 \\
1663\end{array}$ & $\begin{array}{r}100 \\
32 \\
41 \\
60 \\
72\end{array}$ & $\begin{array}{l}71 \\
63 \\
61 \\
65 \\
68\end{array}$ & $\begin{array}{r}2952 \\
886 \\
1092 \\
1712 \\
2007\end{array}$ & $\begin{array}{r}100 \\
30 \\
37 \\
58 \\
68\end{array}$ \\
\hline
\end{tabular}




\begin{tabular}{|c|c|c|c|c|c|c|c|c|c|c|c|c|}
\hline 13 & $\begin{array}{l}\text { 武 } \\
0 \\
\text { 修 }\end{array}$ & $\begin{array}{c}\hat{\delta} \\
60\end{array}$ & $\begin{array}{l}\text { 胃 } \\
\text { 滰 }\end{array}$ & $\begin{array}{c}\text { 胃 } \\
\text { 切 } \\
\text { 除 } \\
\text { B I }\end{array}$ & 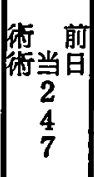 & $\begin{array}{l}2790 \\
1005 \\
1480 \\
2009 \\
2232\end{array}$ & $\begin{array}{r}100 \\
36 \\
53 \\
72 \\
80\end{array}$ & $\begin{array}{r}2215 \\
731 \\
1085 \\
1550 \\
1683\end{array}$ & $\begin{array}{r}100 \\
33 \\
49 \\
70 \\
76\end{array}$ & $\begin{array}{l}79 \\
73 \\
73 \\
77 \\
75\end{array}$ & $\begin{array}{r}3263 \\
946 \\
1370 \\
2009 \\
2284\end{array}$ & $\begin{array}{r}100 \\
29 \\
42 \\
62 \\
70\end{array}$ \\
\hline 14 & $\begin{array}{l}\text { 鉿 } \\
0 \\
\text { 嫄 } \\
0\end{array}$ & $\begin{array}{c}\hat{\delta} \\
62\end{array}$ & $" 1$ & "I & \begin{tabular}{|c} 
術 前 \\
術当白 \\
2 \\
4 \\
7
\end{tabular} & $\begin{array}{l}2645 \\
1190 \\
1323 \\
1640 \\
1746\end{array}$ & $\begin{array}{r}100 \\
45 \\
50 \\
62 \\
66\end{array}$ & $\begin{array}{r}1720 \\
654 \\
705 \\
998 \\
1066\end{array}$ & $\begin{array}{r}100 \\
38 \\
41 \\
58 \\
62\end{array}$ & $\begin{array}{l}65 \\
55 \\
53 \\
61 \\
61\end{array}$ & $\begin{array}{r}2645 \\
846 \\
892 \\
1243 \\
1561\end{array}$ & $\begin{array}{r}100 \\
32 \\
34 \\
47 \\
59\end{array}$ \\
\hline 15 & $\begin{array}{l}\text { 若 } \\
0 \\
\text { 朝 } \\
0\end{array}$ & $\begin{array}{c}\delta \\
55\end{array}$ & $" \prime$ & $\begin{array}{l}\text { 胃 } \\
\text { 晹 } \\
\text { 吻 } \\
\text { 弇 }\end{array}$ & 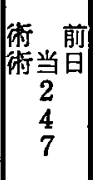 & $\begin{array}{l}2670 \\
1255 \\
1495 \\
1971 \\
2323\end{array}$ & $\begin{array}{r}100 \\
47 \\
56 \\
74 \\
87\end{array}$ & $\begin{array}{r}1935 \\
813 \\
987 \\
1335 \\
1645\end{array}$ & $\begin{array}{r}100 \\
42 \\
51 \\
69 \\
85\end{array}$ & $\begin{array}{l}72 \\
65 \\
66 \\
68 \\
71\end{array}$ & $\begin{array}{l}3173 \\
1174 \\
1469 \\
1999 \\
2634\end{array}$ & $\begin{array}{r}100 \\
37 \\
46 \\
63 \\
83\end{array}$ \\
\hline 16 & $\begin{array}{l}\text { 新 } \\
0 \\
\text { 栄 }\end{array}$ & $\begin{array}{c}\delta \\
45\end{array}$ & $" \prime$ & $\begin{array}{l}\text { 試 } \\
\text { 験 } \\
\text { 閐 } \\
\text { 腹 }\end{array}$ & 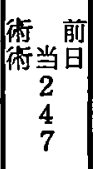 & $\begin{array}{l}2148 \\
1074 \\
1267 \\
1675 \\
1869\end{array}$ & $\begin{array}{r}100 \\
50 \\
59 \\
78 \\
87\end{array}$ & $\begin{array}{r}1626 \\
780 \\
960 \\
1317 \\
1463\end{array}$ & $\begin{array}{r}100 \\
48 \\
59 \\
81 \\
90\end{array}$ & $\begin{array}{l}76 \\
73 \\
76 \\
79 \\
78\end{array}$ & $\begin{array}{r}1973 \\
769 \\
1105 \\
1499 \\
1677\end{array}$ & $\begin{array}{r}100 \\
39 \\
56 \\
76 \\
85\end{array}$ \\
\hline 17 & $\begin{array}{l}\text { 江 } \\
0 \\
\text { 升 } \\
0\end{array}$ & $\begin{array}{c}\text { ๙ } \\
59\end{array}$ & $\begin{array}{l}\text { 食 } \\
\text { 道 } \\
\text { 癌 }\end{array}$ & 瘒 & 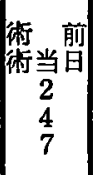 & $\begin{array}{l}2700 \\
1134 \\
1431 \\
1971 \\
2268\end{array}$ & $\begin{array}{r}100 \\
42 \\
53 \\
73 \\
84\end{array}$ & $\begin{array}{r}1630 \\
636 \\
831 \\
1223 \\
1402\end{array}$ & $\begin{array}{r}100 \\
39 \\
51 \\
75 \\
86\end{array}$ & $\begin{array}{l}60 \\
56 \\
58 \\
62 \\
62\end{array}$ & $\begin{array}{l}3042 \\
1126 \\
1339 \\
1977 \\
2432\end{array}$ & $\begin{array}{r}100 \\
37 \\
46 \\
65 \\
80\end{array}$ \\
\hline 18 & $\begin{array}{l}\text { 猪 } \\
0 \\
\text { 義 } \\
0\end{array}$ & $\begin{array}{c}\delta \\
32\end{array}$ & $\begin{array}{l}\text { 胃 } \\
\text { 漬 } \\
\text { 穆 }\end{array}$ & $\begin{array}{c}\text { 胃 } \\
\text { 切 } \\
\text { 除 } \\
\text { B I }\end{array}$ & $\begin{array}{c}\text { 絎前前 } \\
\text { 当昌 } \\
4 \\
7\end{array}$ & $\begin{array}{l}3400 \\
1292 \\
1800 \\
2380 \\
2686\end{array}$ & $\begin{array}{r}100 \\
38 \\
53 \\
70 \\
79\end{array}$ & $\begin{array}{r}2700 \\
945 \\
1296 \\
1917 \\
2160\end{array}$ & $\begin{array}{r}100 \\
35 \\
48 \\
71 \\
80\end{array}$ & $\begin{array}{l}80 \\
73 \\
72 \\
81 \\
80\end{array}$ & $\begin{array}{l}4060 \\
1177 \\
1543 \\
2558 \\
3000\end{array}$ & $\begin{array}{r}100 \\
29 \\
38 \\
63 \\
74\end{array}$ \\
\hline 19 & $\begin{array}{c}\text { 浜 } \\
0 \\
\text { 孝 } \\
0\end{array}$ & $\begin{array}{c}\hat{\delta} \\
42\end{array}$ & $" \prime$ & "I & $\begin{array}{c}\text { 杪 前 } \\
\text { 術当白 } \\
2 \\
4 \\
7\end{array}$ & $\begin{array}{l}3360 \\
1310 \\
1680 \\
2486 \\
2688\end{array}$ & $\begin{array}{r}100 \\
39 \\
50 \\
74 \\
80\end{array}$ & $\begin{array}{r}2655 \\
956 \\
1274 \\
1938 \\
2336\end{array}$ & $\begin{array}{r}100 \\
36 \\
48 \\
73 \\
78\end{array}$ & $\begin{array}{l}79 \\
73 \\
76 \\
78 \\
87\end{array}$ & $\begin{array}{l}4090 \\
1227 \\
1554 \\
2495 \\
2945\end{array}$ & $\begin{array}{r}100 \\
30 \\
38 \\
61 \\
72\end{array}$ \\
\hline 20 & $\begin{array}{c}\text { 田 } \\
0 \\
\text { 居 } \\
0\end{array}$ & $\begin{array}{c}\hat{\delta} \\
50\end{array}$ & $" \prime$ & 11 & 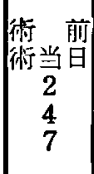 & $\begin{array}{l}3900 \\
1482 \\
2028 \\
2847 \\
3120\end{array}$ & $\begin{array}{r}100 \\
38 \\
52 \\
73 \\
80\end{array}$ & $\begin{array}{l}3150 \\
1134 \\
1512 \\
2205 \\
2426\end{array}$ & $\begin{array}{r}100 \\
36 \\
48 \\
70 \\
77\end{array}$ & $\begin{array}{l}81 \\
76 \\
75 \\
77 \\
78\end{array}$ & $\begin{array}{l}4260 \\
1278 \\
1789 \\
2684 \\
3067\end{array}$ & $\begin{array}{r}100 \\
30 \\
42 \\
63 \\
72\end{array}$ \\
\hline 21 & $\begin{array}{l}\text { 售 } \\
0 \\
\text { 彦 } \\
0\end{array}$ & $\begin{array}{c}\hat{\sigma} \\
42\end{array}$ & 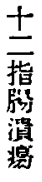 & $" \prime$ & $\begin{array}{c}\text { 攸前煎 } \\
\text { 当 } \\
2 \\
4 \\
7\end{array}$ & $\begin{array}{l}3800 \\
1445 \\
2622 \\
2925 \\
3268\end{array}$ & $\begin{array}{r}100 \\
38 \\
69 \\
77 \\
86\end{array}$ & $\begin{array}{l}3370 \\
1180 \\
2290 \\
2629 \\
2865\end{array}$ & $\begin{array}{r}100 \\
35 \\
68 \\
78 \\
85\end{array}$ & $\begin{array}{l}88 \\
82 \\
87 \\
90 \\
88\end{array}$ & $\begin{array}{l}4150 \\
1370 \\
2655 \\
3030 \\
3320\end{array}$ & $\begin{array}{r}100 \\
33 \\
64 \\
73 \\
80\end{array}$ \\
\hline 22 & $\begin{array}{l}\text { 模 } \\
0 \\
\text { 尚 }\end{array}$ & $\begin{array}{c}\hat{\delta} \\
26\end{array}$ & 11 & 11 & 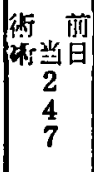 & $\begin{array}{l}3760 \\
1767 \\
2707 \\
2858 \\
3120\end{array}$ & $\begin{array}{r}100 \\
47 \\
72 \\
76 \\
83\end{array}$ & $\begin{array}{l}3420 \\
1505 \\
2360 \\
2565 \\
2907\end{array}$ & $\begin{array}{r}100 \\
44 \\
69 \\
75 \\
85\end{array}$ & $\begin{array}{l}91 \\
85 \\
87 \\
90 \\
93\end{array}$ & $\begin{array}{l}4353 \\
1698 \\
2525 \\
3003 \\
3395\end{array}$ & $\begin{array}{r}100 \\
39 \\
58 \\
69 \\
78\end{array}$ \\
\hline
\end{tabular}


第 1 号 蟹江：手術の换気機能うよび動脈血ガス分俚におよほす影響

\begin{tabular}{|c|c|c|c|c|c|c|c|c|c|c|c|c|}
\hline 33 & $\begin{array}{l}山 \\
0 \\
\text { 和 } \\
0\end{array}$ & $\begin{array}{l}\text { 우 } \\
36\end{array}$ & $\begin{array}{l}\text { 睗 } \\
\text { 虑 } \\
\text { 着 } \\
\text { 应 }\end{array}$ & $\begin{array}{l}\text { 腸 } \\
\text { 切 } \\
\text { 除 } \\
\text { 術 }\end{array}$ & $\begin{array}{c}\text { 術 } \\
\text { 前削当 } \\
2 \\
4 \\
7\end{array}$ & $\begin{array}{l}1978 \\
1075 \\
1290 \\
1720 \\
1892\end{array}$ & $\begin{array}{r}100 \\
54 \\
65 \\
87 \\
95\end{array}$ & $\begin{array}{r}1398 \\
710 \\
860 \\
1185 \\
1362\end{array}$ & $\begin{array}{r}100 \\
51 \\
62 \\
85 \\
97\end{array}$ & $\begin{array}{l}71 \\
66 \\
67 \\
69 \\
77\end{array}$ & $\begin{array}{r}1662 \\
591 \\
826 \\
912 \\
1589\end{array}$ & $\begin{array}{r}100 \\
36 \\
50 \\
55 \\
95\end{array}$ \\
\hline 34 & $\begin{array}{l}\text { 宾 } \\
0 \\
\text { 消 } \\
0\end{array}$ & $\begin{array}{l}\text { 우 } \\
26\end{array}$ & $" \prime$ & $\begin{array}{l}\text { 瘺 } \\
\text { 着 } \\
\text { 刽 } \\
\text { 離 }\end{array}$ & $\begin{array}{c}\text { 竹前煎 } \\
2 \\
4 \\
7\end{array}$ & $\begin{array}{l}2140 \\
1156 \\
1540 \\
1798 \\
1905\end{array}$ & $\begin{array}{r}100 \\
54 \\
72 \\
84 \\
89\end{array}$ & $\begin{array}{r}1810 \\
941 \\
1285 \\
1538 \\
1630\end{array}$ & $\begin{array}{r}100 \\
52 \\
71 \\
85 \\
90\end{array}$ & $\begin{array}{l}85 \\
81 \\
83 \\
86 \\
86\end{array}$ & $\begin{array}{l}2346 \\
1126 \\
1525 \\
2018 \\
2135\end{array}$ & $\begin{array}{r}100 \\
48 \\
65 \\
86 \\
91\end{array}$ \\
\hline 35 & $\begin{array}{l}\text { 高 } \\
\text { 美 } \\
\bigcirc \\
\text { 美 }\end{array}$ & $\begin{array}{l}\text { 令 } \\
19\end{array}$ & "I & $" 1$ & $\begin{array}{c}\text { 棌 } \\
\text { 前前当 } \\
2 \\
4 \\
7\end{array}$ & $\begin{array}{l}2700 \\
1545 \\
1890 \\
2295 \\
2511\end{array}$ & $\begin{array}{r}100 \\
57 \\
70 \\
85 \\
93\end{array}$ & $\begin{array}{l}2350 \\
1270 \\
1598 \\
2020 \\
2139\end{array}$ & $\begin{array}{r}100 \\
54 \\
68 \\
86 \\
91\end{array}$ & $\begin{array}{l}87 \\
82 \\
85 \\
88 \\
85\end{array}$ & $\begin{array}{l}3178 \\
1462 \\
1716 \\
2606 \\
2860\end{array}$ & $\begin{array}{r}100 \\
46 \\
54 \\
82 \\
90\end{array}$ \\
\hline 36 & $\begin{array}{l}\text { 作 } \\
0 \\
0 \\
+ \\
0 \\
0\end{array}$ & $\begin{array}{l}\frac{1}{\delta} \\
33\end{array}$ & $\begin{array}{l}\text { 急 } \\
\text { 殅 } \\
\text { 哣 } \\
\text { 荻 }\end{array}$ & 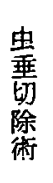 & \begin{tabular}{|c} 
術 \\
郝当前 \\
2 \\
4 \\
7
\end{tabular} & $\begin{array}{l}3476 \\
1909 \\
3019 \\
3123 \\
3400\end{array}$ & $\begin{array}{r}100 \\
55 \\
87 \\
90 \\
98\end{array}$ & $\begin{array}{l}2950 \\
1652 \\
2596 \\
2685 \\
2920\end{array}$ & $\begin{array}{r}100 \\
56 \\
88 \\
91 \\
99\end{array}$ & $\begin{array}{l}85 \\
87 \\
86 \\
86 \\
86\end{array}$ & $\begin{array}{l}3774 \\
1812 \\
2868 \\
3132 \\
3397\end{array}$ & $\begin{array}{r}100 \\
48 \\
76 \\
83 \\
90\end{array}$ \\
\hline 37 & $\begin{array}{l}\text { 感 } \\
0 \\
\text { 喜 } \\
0\end{array}$ & $\begin{array}{c}\text { 9 } \\
20\end{array}$ & $"$ & " & \begin{tabular}{|c} 
街前前当 \\
2 \\
4 \\
7
\end{tabular} & $\begin{array}{l}2675 \\
1498 \\
1605 \\
2327 \\
2515\end{array}$ & $\begin{array}{r}100 \\
56 \\
60 \\
87 \\
94\end{array}$ & $\begin{array}{l}2098 \\
1133 \\
1300 \\
1783 \\
1890\end{array}$ & $\begin{array}{r}100 \\
54 \\
62 \\
85 \\
90\end{array}$ & $\begin{array}{l}78 \\
76 \\
81 \\
77 \\
75\end{array}$ & $\begin{array}{l}3205 \\
1282 \\
1730 \\
2532 \\
2756\end{array}$ & $\begin{array}{r}100 \\
40 \\
54 \\
79 \\
86\end{array}$ \\
\hline 38 & $\begin{array}{l}\text { 佐 } \\
0 \\
\text { 修 }\end{array}$ & $\begin{array}{c}\delta \\
24\end{array}$ & "I & $\prime \prime$ & $\begin{array}{c}\text { 尃前前当 } \\
2 \\
4 \\
7\end{array}$ & $\begin{array}{l}3780 \\
1966 \\
2381 \\
2984 \\
3364\end{array}$ & $\begin{array}{r}100 \\
52 \\
63 \\
78 \\
89\end{array}$ & $\begin{array}{l}3165 \\
1583 \\
1962 \\
2532 \\
2943\end{array}$ & $\begin{array}{r}100 \\
50 \\
62 \\
80 \\
93\end{array}$ & $\begin{array}{l}84 \\
81 \\
82 \\
86 \\
87\end{array}$ & $\begin{array}{l}4278 \\
1925 \\
2310 \\
3337 \\
3935\end{array}$ & $\begin{array}{r}100 \\
45 \\
54 \\
78 \\
92\end{array}$ \\
\hline 39 & $\begin{array}{l}\text { 平 } \\
\text { ○ } \\
\text { 明 }\end{array}$ & $\begin{array}{l}\text { 今 } \\
24\end{array}$ & 11 & "I & $\begin{array}{c}\text { 䘖 前 } \\
\text { 前当白 } \\
2 \\
4 \\
7\end{array}$ & $\begin{array}{l}4250 \\
2465 \\
3570 \\
3868 \\
4123\end{array}$ & $\begin{array}{r}100 \\
58 \\
84 \\
91 \\
97\end{array}$ & $\begin{array}{l}3650 \\
2080 \\
3030 \\
3358 \\
3577\end{array}$ & $\begin{array}{r}100 \\
57 \\
83 \\
92 \\
98\end{array}$ & $\begin{array}{l}86 \\
84 \\
85 \\
87 \\
87\end{array}$ & $\begin{array}{l}4645 \\
2322 \\
3530 \\
3948 \\
4180\end{array}$ & $\begin{array}{r}100 \\
50 \\
76 \\
85 \\
90\end{array}$ \\
\hline 40 & $\begin{array}{l}\text { 森 } \\
0 \\
\text { 静 } \\
0\end{array}$ & $\begin{array}{c}+ \\
24\end{array}$ & 11 & "I & $\begin{array}{c}\text { 術前 } \\
\text { 前当 } \\
2 \\
4 \\
7\end{array}$ & $\begin{array}{l}2450 \\
1397 \\
1764 \\
2107 \\
2400\end{array}$ & $\begin{array}{r}100 \\
57 \\
72 \\
86 \\
98\end{array}$ & $\begin{array}{l}2035 \\
1079 \\
1465 \\
1730 \\
1933\end{array}$ & $\begin{array}{r}100 \\
53 \\
72 \\
85 \\
95\end{array}$ & $\begin{array}{l}83 \\
77 \\
83 \\
82 \\
81\end{array}$ & $\begin{array}{l}2670 \\
1335 \\
1789 \\
2189 \\
2430\end{array}$ & $\begin{array}{r}100 \\
50 \\
67 \\
82 \\
91\end{array}$ \\
\hline 41 & $\begin{array}{l}\text { 高 } \\
0 \\
0 \\
\text { 繁 } \\
0\end{array}$ & $\begin{array}{c}\text { 우 } \\
14\end{array}$ & "I & 11 & $\begin{array}{c}\text { 術前前 } \\
\text { 当 } \\
4 \\
7\end{array}$ & $\begin{array}{l}2184 \\
1180 \\
1485 \\
1856 \\
2075\end{array}$ & $\begin{array}{r}100 \\
54 \\
68 \\
85 \\
95\end{array}$ & $\begin{array}{l}1930 \\
1023 \\
1293 \\
1660 \\
1872\end{array}$ & $\begin{array}{r}100 \\
53 \\
67 \\
86 \\
97\end{array}$ & $\begin{array}{l}88 \\
87 \\
87 \\
89 \\
90\end{array}$ & $\begin{array}{l}2473 \\
1180 \\
1533 \\
1929 \\
2200\end{array}$ & $\begin{array}{r}100 \\
48 \\
62 \\
78 \\
89\end{array}$ \\
\hline 42 & $\begin{array}{l}\text { 中 } \\
0 \\
\text { 正 } \\
0\end{array}$ & $\begin{array}{c}\delta \\
19\end{array}$ & $\begin{array}{l}\text { 鼠 } \\
\hat{\text { ヘ }} \\
\text { 三 } \\
\bar{r}\end{array}$ & $\begin{array}{l}\text { 根 } \\
\text { 治 } \\
\text { 手 } \\
\text { 術 }\end{array}$ & \begin{tabular}{|c} 
術前煎 \\
2 \\
4 \\
7
\end{tabular} & $\begin{array}{l}3912 \\
2425 \\
2855 \\
2403 \\
3755\end{array}$ & $\begin{array}{r}100 \\
62 \\
73 \\
87 \\
96\end{array}$ & $\begin{array}{l}3455 \\
2038 \\
2418 \\
3075 \\
3248\end{array}$ & $\begin{array}{r}100 \\
59 \\
70 \\
89 \\
94\end{array}$ & $\begin{array}{l}88 \\
84 \\
85 \\
90 \\
86\end{array}$ & $\begin{array}{l}4370 \\
2272 \\
3015 \\
3452 \\
3845\end{array}$ & $\begin{array}{r}100 \\
52 \\
69 \\
79 \\
88\end{array}$ \\
\hline
\end{tabular}




\begin{tabular}{|c|c|c|c|c|c|c|c|c|c|c|c|c|}
\hline 23 & $\begin{array}{l}\text { 神 } \\
0 \\
\text { 興 } \\
0\end{array}$ & $\begin{array}{l}f \\
65\end{array}$ & $\begin{array}{l}\text { 䏣 } \\
\text { 石 }\end{array}$ & $\begin{array}{l}\text { 盟 } \\
\text { 栾 } \\
\text { 摘 } \\
\text { 出 }\end{array}$ & 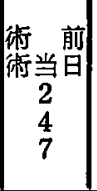 & $\begin{array}{r}1950 \\
683 \\
956 \\
1307 \\
1463\end{array}$ & $\begin{array}{r}100 \\
35 \\
49 \\
67 \\
75\end{array}$ & $\begin{array}{r}1360 \\
435 \\
626 \\
885 \\
1993\end{array}$ & $\begin{array}{r}100 \\
32 \\
46 \\
65 \\
73\end{array}$ & $\begin{array}{l}70 \\
64 \\
65 \\
68 \\
68\end{array}$ & $\begin{array}{r}1875 \\
563 \\
825 \\
1181 \\
1331\end{array}$ & $\begin{array}{r}100 \\
30 \\
44 \\
63 \\
71\end{array}$ \\
\hline 24 & $\begin{array}{l}- \\
0 \\
\text { 輝 } \\
0\end{array}$ & $\begin{array}{c}\hat{\delta} \\
25\end{array}$ & $"$ & $" 1$ & 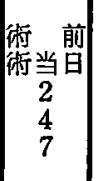 & $\begin{array}{r}2365 \\
860 \\
990 \\
1420 \\
1720\end{array}$ & $\begin{array}{r}100 \\
36 \\
42 \\
60 \\
73\end{array}$ & $\begin{array}{r}2150 \\
560 \\
689 \\
1075 \\
1505\end{array}$ & $\begin{array}{r}100 \\
26 \\
32 \\
50 \\
70\end{array}$ & $\begin{array}{l}91 \\
65 \\
70 \\
76 \\
88\end{array}$ & $\begin{array}{r}3194 \\
560 \\
752 \\
1420 \\
2150\end{array}$ & $\begin{array}{r}100 \\
18 \\
24 \\
45 \\
68\end{array}$ \\
\hline 25 & $\begin{array}{l}\text { 小 } \\
0 \\
w \\
0\end{array}$ & $\begin{array}{c}\text { 우 } \\
54\end{array}$ & $\prime \prime$ & $" 1$ & \begin{tabular}{|c|} 
仯前前 \\
2 \\
4 \\
7
\end{tabular} & $\begin{array}{r}2400 \\
816 \\
1272 \\
1488 \\
1752\end{array}$ & $\begin{array}{r}100 \\
34 \\
53 \\
62 \\
73\end{array}$ & $\begin{array}{r}1720 \\
595 \\
963 \\
1100 \\
1275\end{array}$ & $\begin{array}{r}100 \\
35 \\
56 \\
64 \\
75\end{array}$ & $\begin{array}{l}72 \\
73 \\
76 \\
74 \\
73\end{array}$ & $\begin{array}{r}2380 \\
738 \\
1238 \\
1428 \\
1714\end{array}$ & $\begin{array}{r}100 \\
31 \\
52 \\
60 \\
72\end{array}$ \\
\hline 26 & $\begin{array}{l}\text { 高 } \\
0 \\
5 \\
0\end{array}$ & $\begin{array}{l}9 \\
33\end{array}$ & 癌 & $\begin{array}{l}\text { 試 } \\
\text { 験 } \\
\text { 開 } \\
\text { 腹 }\end{array}$ & $\mid \begin{array}{c}\text { 桬 } \\
\text { 前当前 } \\
2 \\
4 \\
7\end{array}$ & $\begin{array}{r}2000 \\
800 \\
1100 \\
1300 \\
1500\end{array}$ & $\begin{array}{r}100 \\
40 \\
55 \\
65 \\
75\end{array}$ & $\begin{array}{r}1641 \\
607 \\
836 \\
1033 \\
1180\end{array}$ & $\begin{array}{r}100 \\
37 \\
51 \\
63 \\
72\end{array}$ & $\begin{array}{l}82 \\
76 \\
76 \\
79 \\
79\end{array}$ & $\begin{array}{r}2230 \\
802 \\
1070 \\
1338 \\
1606\end{array}$ & $\begin{array}{r}\text { t00 } \\
36 \\
48 \\
60 \\
72\end{array}$ \\
\hline 27 & $\begin{array}{l}\text { 俈 } \\
\text { O } \\
\text { O } \\
\text { 陽 }\end{array}$ & $\begin{array}{c}q \\
27\end{array}$ & $\begin{array}{l}\text { 慢 } \\
\text { 生 } \\
\text { 便 } \\
\text { 秘 }\end{array}$ & $\begin{array}{l}\text { 結 } \\
\text { 腸 } \\
\text { 荡 } \\
\text { 除 }\end{array}$ & 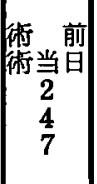 & $\begin{array}{r}2537 \\
645 \\
1075 \\
1296 \\
1806\end{array}$ & $\begin{array}{r}100 \\
25 \\
42 \\
51 \\
71\end{array}$ & $\begin{array}{r}2193 \\
452 \\
731 \\
1010 \\
1333\end{array}$ & $\begin{array}{r}100 \\
21 \\
34 \\
46 \\
61\end{array}$ & $\begin{array}{l}86 \\
70 \\
68 \\
79 \\
75\end{array}$ & $\begin{array}{r}3044 \\
468 \\
860 \\
1032 \\
1598\end{array}$ & $\begin{array}{r}100 \\
16 \\
29 \\
34 \\
55\end{array}$ \\
\hline 28 & $\begin{array}{l}\text { 中 } \\
\text { 小 } \\
\text { 小 } \\
\text { 子 }\end{array}$ & $\begin{array}{c}\text { + } \\
42\end{array}$ & $"$ & $\prime \prime$ & $\begin{array}{c}\text { 莠 } \\
\text { 前前当 } \\
2 \\
4 \\
7\end{array}$ & $\begin{array}{r}2300 \\
990 \\
1200 \\
1450 \\
1700\end{array}$ & $\begin{array}{r}100 \\
43 \\
52 \\
63 \\
74\end{array}$ & $\begin{array}{r}1870 \\
748 \\
954 \\
1178 \\
1310\end{array}$ & $\begin{array}{r}100 \\
40 \\
51 \\
63 \\
70\end{array}$ & $\begin{array}{l}81 \\
76 \\
80 \\
81 \\
77\end{array}$ & $\begin{array}{r}2544 \\
967 \\
1200 \\
1526 \\
1730\end{array}$ & $\begin{array}{r}100 \\
38 \\
48 \\
60 \\
68\end{array}$ \\
\hline 29 & $\begin{array}{l}\text { 星 } \\
0 \\
\text { み } \\
0\end{array}$ & $\begin{array}{c}f \\
65\end{array}$ & $" \prime$ & $\begin{array}{l}\text { 結 } \\
\text { 笏 } \\
\text { 切 } \\
\text { 除 }\end{array}$ & \begin{tabular}{|c} 
攸前前 \\
当的 \\
4 \\
7
\end{tabular} & $\begin{array}{r}2200 \\
792 \\
990 \\
1298 \\
1540\end{array}$ & $\begin{array}{r}100 \\
36 \\
45 \\
59 \\
70\end{array}$ & $\begin{array}{r}1540 \\
570 \\
708 \\
940 \\
1124\end{array}$ & $\begin{array}{r}100 \\
37 \\
46 \\
61 \\
73\end{array}$ & $\begin{array}{l}70 \\
72 \\
72 \\
72 \\
73\end{array}$ & $\begin{array}{r}2070 \\
704 \\
973 \\
1304 \\
1490\end{array}$ & $\begin{array}{r}100 \\
34 \\
47 \\
63 \\
72\end{array}$ \\
\hline 30 & $\begin{array}{l}\text { 松 } \\
0 \\
\text { 美 } \\
0\end{array}$ & $\begin{array}{c}\text { + } \\
42\end{array}$ & 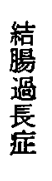 & $\begin{array}{l}\text { S切 } \\
\text { 字 } \\
\text { 状除 } \\
\text { 結 } \\
\text { 腸涤 }\end{array}$ & $\begin{array}{c}\text { 集 前 } \\
\text { 前当日 } \\
2 \\
4 \\
7\end{array}$ & $\begin{array}{l}2400 \\
1152 \\
1340 \\
1632 \\
1872\end{array}$ & $\begin{array}{r}100 \\
48 \\
56 \\
68 \\
78\end{array}$ & $\begin{array}{r}1820 \\
783 \\
946 \\
1183 \\
1400\end{array}$ & $\begin{array}{r}100 \\
43 \\
52 \\
65 \\
77\end{array}$ & $\begin{array}{l}79 \\
68 \\
71 \\
72 \\
75\end{array}$ & $\begin{array}{r}2670 \\
962 \\
1229 \\
1657 \\
1876\end{array}$ & $\begin{array}{r}100 \\
36 \\
46 \\
62 \\
71\end{array}$ \\
\hline 31 & $\begin{array}{l}\text { 神 } \\
0 \\
i \\
0\end{array}$ & $\begin{array}{c}\text { ㅇ } \\
82\end{array}$ & $\begin{array}{l}\text { 結 } \\
\text { 腸 } \\
\text { 癌 }\end{array}$ & 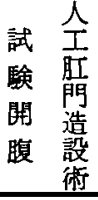 & 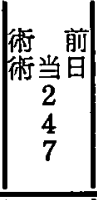 & $\begin{array}{r}1670 \\
534 \\
919 \\
1136 \\
1237\end{array}$ & $\begin{array}{r}200 \\
32 \\
55 \\
68 \\
74\end{array}$ & $\begin{array}{r}1205 \\
376 \\
639 \\
844 \\
916\end{array}$ & $\begin{array}{r}100 \\
31 \\
53 \\
70 \\
76\end{array}$ & $\begin{array}{l}72 \\
70 \\
70 \\
74 \\
74\end{array}$ & $\begin{array}{r}1530 \\
428 \\
643 \\
964 \\
1071\end{array}$ & $\begin{array}{r}100 \\
28 \\
42 \\
63 \\
70\end{array}$ \\
\hline 32 & $\begin{array}{l}\text { 河 } \\
\text { O } \\
\text { 美 } \\
0 \\
0\end{array}$ & $\begin{array}{l}\text { 우 } \\
42\end{array}$ & $\begin{array}{l}\text { 續 } \\
\text { 転 } \\
\text { 洺 } \\
\text { 澏 }\end{array}$ & $\begin{array}{l}\text { 試 } \\
\text { 験 } \\
\text { 開 } \\
\text { 腹 }\end{array}$ & $\begin{array}{c}\text { 梅前前 } \\
\text { 当日 } \\
2 \\
4 \\
7\end{array}$ & $\begin{array}{l}2240 \\
1008 \\
1344 \\
1658 \\
1837\end{array}$ & $\begin{array}{r}100 \\
45 \\
60 \\
74 \\
82\end{array}$ & $\begin{array}{r}1820 \\
764 \\
1020 \\
1310 \\
1456\end{array}$ & $\begin{array}{r}100 \\
42 \\
56 \\
72 \\
80\end{array}$ & $\begin{array}{l}81 \\
76 \\
76 \\
79 \\
79\end{array}$ & $\begin{array}{r}2415 \\
918 \\
1183 \\
1570 \\
1884\end{array}$ & $\begin{array}{r}100 \\
38 \\
49 \\
65 \\
78\end{array}$ \\
\hline
\end{tabular}




\begin{tabular}{|c|c|c|c|c|c|c|c|c|c|c|c|c|}
\hline 43 & $\begin{array}{l}\text { 平 } \\
\text { 明 }\end{array}$ & $\begin{array}{c}\text { 令 } \\
24\end{array}$ & $\begin{array}{l}\text { 骨 } \\
\text { 盤 } \\
\text { 擅 } \\
\text { 膜 } \\
\text { 炎 }\end{array}$ & $\begin{array}{l}\text { 切ナ } \\
\text { 開 } \\
\dot{i} \\
\dot{2} \\
\dot{v}\end{array}$ & 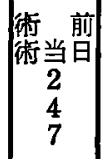 & $\begin{array}{l}2600 \\
1300 \\
1742 \\
2052 \\
2314\end{array}$ & $\begin{array}{r}100 \\
50 \\
67 \\
79 \\
89\end{array}$ & $\begin{array}{r}2100 \\
966 \\
1365 \\
1510 \\
1805\end{array}$ & $\begin{array}{r}100 \\
46 \\
65 \\
72 \\
86\end{array}$ & $\begin{array}{l}81 \\
74 \\
78 \\
74 \\
78\end{array}$ & $\begin{array}{l}2542 \\
1017 \\
1627 \\
1800 \\
2160\end{array}$ & $\begin{array}{r}100 \\
40 \\
64 \\
70 \\
85\end{array}$ \\
\hline 44 & $\begin{array}{c}\text { 宮 } \\
\text { 敏 } \\
0\end{array}$ & $\begin{array}{c}\text { 우 } \\
36\end{array}$ & $\begin{array}{l}\text { 子 } \\
\text { 宮 } \\
\text { 筋 } \\
\text { 腫 }\end{array}$ & $\begin{array}{l}\text { 子 } \\
\text { 宮 } \\
\text { 断 } \\
\text { 郝 }\end{array}$ & $\mid \begin{array}{c}\text { 術 前 } \\
\text { 術当白 } \\
2 \\
4 \\
7\end{array}$ & $\begin{array}{l}2300 \\
1550 \\
1886 \\
2050 \\
2151\end{array}$ & $\begin{array}{r}100 \\
68 \\
82 \\
89 \\
94\end{array}$ & $\begin{array}{l}1850 \\
1184 \\
1462 \\
1591 \\
1758\end{array}$ & $\begin{array}{r}100 \\
64 \\
78 \\
86 \\
95\end{array}$ & $\begin{array}{l}80 \\
76 \\
78 \\
78 \\
82\end{array}$ & $\begin{array}{l}2350 \\
1128 \\
1833 \\
1880 \\
1238\end{array}$ & $\begin{array}{r}100 \\
48 \\
78 \\
80 \\
91\end{array}$ \\
\hline 45 & $\begin{array}{l}\text { 上 } \\
\mathrm{O} \\
\text { 端 } \\
0\end{array}$ & $\begin{array}{c}\text { 우 } \\
42\end{array}$ & " & $\begin{array}{l}\text { 子 } \\
\text { 宮 } \\
\text { 除 } \\
\text { 桜 }\end{array}$ & \begin{tabular}{|c|} 
縛当前 \\
2 \\
4 \\
7
\end{tabular} & $\begin{array}{l}2742 \\
1617 \\
1863 \\
1945 \\
2356\end{array}$ & $\begin{array}{r}100 \\
59 \\
68 \\
71 \\
86\end{array}$ & $\begin{array}{l}2250 \\
1260 \\
1507 \\
1643 \\
2025\end{array}$ & $\begin{array}{r}100 \\
56 \\
67 \\
73 \\
90\end{array}$ & $\begin{array}{l}82 \\
78 \\
81 \\
84 \\
86\end{array}$ & $\begin{array}{l}2578 \\
1340 \\
1624 \\
1778 \\
2088\end{array}$ & $\begin{array}{r}100 \\
52 \\
63 \\
69 \\
81\end{array}$ \\
\hline 46 & $\begin{array}{l}\text { 岩 } \\
\text { ○ } \\
\text { 富 } \\
\bigcirc\end{array}$ & $\begin{array}{c}f \\
34\end{array}$ & $" \prime$ & $\begin{array}{l}\text { 子 } \\
\text { 富 } \\
\text { 断 } \\
\text { 䔎 }\end{array}$ & 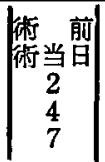 & $\begin{array}{l}2903 \\
1568 \\
1945 \\
2497 \\
2670\end{array}$ & $\begin{array}{r}100 \\
54 \\
67 \\
86 \\
92\end{array}$ & $\begin{array}{l}2365 \\
1183 \\
1490 \\
2010 \\
2223\end{array}$ & $\begin{array}{r}100 \\
50 \\
63 \\
85 \\
94\end{array}$ & $\begin{array}{l}81 \\
75 \\
77 \\
80 \\
83\end{array}$ & $\begin{array}{l}3257 \\
1498 \\
1694 \\
2638 \\
2931\end{array}$ & $\begin{array}{r}100 \\
46 \\
52 \\
81 \\
90\end{array}$ \\
\hline 47 & $\begin{array}{l}\text { 滝 } \\
\text { O } \\
\text { 保 } \\
\bigcirc\end{array}$ & $\begin{array}{c}\text { 우 } \\
25\end{array}$ & $\begin{array}{l}\text { 笈 } \\
\text { 策 } \\
\text { 重 } \\
\text { 腫 }\end{array}$ & 出 & 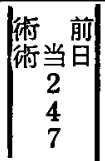 & $\begin{array}{l}2560 \\
1740 \\
1971 \\
2278 \\
2458\end{array}$ & $\begin{array}{r}100 \\
68 \\
77 \\
89 \\
96\end{array}$ & $\begin{array}{l}2120 \\
1420 \\
1590 \\
1908 \\
2014\end{array}$ & $\begin{array}{r}100 \\
67 \\
75 \\
99 \\
95\end{array}$ & $\begin{array}{l}83 \\
82 \\
81 \\
84 \\
82\end{array}$ & $\begin{array}{l}2645 \\
1481 \\
1878 \\
2195 \\
2380\end{array}$ & $\begin{array}{r}100 \\
56 \\
71 \\
83 \\
90\end{array}$ \\
\hline 48 & $\begin{array}{l}\text { 谷 } \\
\text { 静 } \\
0\end{array}$ & $\begin{array}{c}\text { 우 } \\
23\end{array}$ & "I & "I & \begin{tabular}{|c|} 
攸前前 \\
当日 \\
2 \\
4 \\
7
\end{tabular} & $\begin{array}{l}2450 \\
1593 \\
1764 \\
2107 \\
2303\end{array}$ & $\begin{array}{r}100 \\
65 \\
72 \\
86 \\
94\end{array}$ & $\begin{array}{l}1972 \\
1241 \\
1379 \\
1675 \\
1870\end{array}$ & $\begin{array}{r}100 \\
63 \\
70 \\
85 \\
95\end{array}$ & $\begin{array}{l}80 \\
78 \\
78 \\
79 \\
81\end{array}$ & $\begin{array}{l}2890 \\
1503 \\
1764 \\
2370 \\
2688\end{array}$ & $\begin{array}{r}100 \\
52 \\
61 \\
82 \\
93\end{array}$ \\
\hline 49 & $\begin{array}{l}\text { 西 } \\
\text { 寔 }\end{array}$ & $\begin{array}{c}\text { 今 } \\
29\end{array}$ & $\begin{array}{l}\text { 頉 } \\
\text { 腺 } \\
\text { 結 } \\
\text { 核 }\end{array}$ & 出 & $\begin{array}{c}\text { 攸 } \\
\text { 前 } \\
\text { 当日 } \\
2 \\
4 \\
7\end{array}$ & $\begin{array}{l}3700 \\
1998 \\
2886 \\
3478 \\
3663\end{array}$ & $\begin{array}{r}100 \\
54 \\
78 \\
94 \\
99\end{array}$ & $\begin{array}{l}3350 \\
1742 \\
2546 \\
3115 \\
3216\end{array}$ & $\begin{array}{r}100 \\
53 \\
76 \\
93 \\
96\end{array}$ & $\begin{array}{l}90 \\
87 \\
88 \\
90 \\
88\end{array}$ & $\begin{array}{l}4540 \\
2178 \\
3587 \\
4268 \\
4404\end{array}$ & $\begin{array}{r}100 \\
48 \\
79 \\
94 \\
97\end{array}$ \\
\hline 50 & $\begin{array}{l}\text { 菘 } \\
\text { 信 } \\
\text { O }\end{array}$ & $\begin{array}{c}\widehat{\delta} \\
26\end{array}$ & 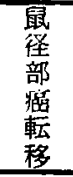 & $\begin{array}{l}\text { 試 } \\
\text { 験 } \\
\text { 摘 } \\
\text { 出 }\end{array}$ & $\begin{array}{c}\text { 少 } \\
\text { 前前 } \\
2 \\
2 \\
4 \\
7\end{array}$ & $\begin{array}{l}3660 \\
2305 \\
3075 \\
3514 \\
3587\end{array}$ & $\begin{array}{r}100 \\
63 \\
84 \\
96 \\
98\end{array}$ & $\begin{array}{l}3280 \\
2000 \\
2624 \\
3116 \\
3182\end{array}$ & $\begin{array}{r}100 \\
61 \\
80 \\
95 \\
97\end{array}$ & $\begin{array}{l}90 \\
87 \\
85 \\
89 \\
89\end{array}$ & $\begin{array}{l}4175 \\
2338 \\
3256 \\
3590 \\
3882\end{array}$ & $\begin{array}{r}100 \\
56 \\
78 \\
86 \\
93\end{array}$ \\
\hline 51 & $\begin{array}{l}\text { 渡 } \\
\text { 陽 } \\
\bigcirc\end{array}$ & $\begin{array}{c}\text { 우 } \\
27\end{array}$ & 石 & 出 & 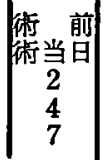 & $\begin{array}{l}2515 \\
\text { 䐓 定不 } \\
1860 \\
2012 \\
2238\end{array}$ & $\begin{array}{r}100 \\
r \text { 能 } \\
74 \\
80 \\
89\end{array}$ & $\begin{array}{l}1930 \\
1312 \\
1448 \\
1756\end{array}$ & $\begin{array}{r}100 \\
68 \\
75 \\
91\end{array}$ & $\begin{array}{l}77 \\
71 \\
72 \\
78\end{array}$ & $\begin{array}{l}2980 \\
1937 \\
2145 \\
2503\end{array}$ & $\begin{array}{r}100 \\
\\
65 \\
72 \\
84\end{array}$ \\
\hline 52 & $\begin{array}{l}\text { 年 } \\
\text { 号 }\end{array}$ & $\begin{array}{c}\hat{\jmath} \\
27\end{array}$ & $\begin{array}{l}\text { 鼠腺 } \\
\text { 炎 } \\
\stackrel{2}{\text { パ }}\end{array}$ & 出 & \begin{tabular}{|c|} 
街 前 \\
当日 \\
2 \\
4 \\
7
\end{tabular} & $\begin{array}{l}3970 \\
3017 \\
3578 \\
3890 \\
3970\end{array}$ & $\begin{array}{r}100 \\
76 \\
90 \\
98 \\
100\end{array}$ & $\begin{array}{l}3160 \\
2306 \\
2686 \\
3034 \\
3097\end{array}$ & $\begin{array}{r}100 \\
73 \\
85 \\
96 \\
98\end{array}$ & $\begin{array}{l}80 \\
76 \\
75 \\
78 \\
78\end{array}$ & $\begin{array}{l}4375 \\
2800 \\
3412 \\
3631 \\
3981\end{array}$ & $\begin{array}{r}100 \\
64 \\
78 \\
83 \\
91\end{array}$ \\
\hline 53 & $\begin{array}{l}\text { 新 } \\
\text { 栄 }\end{array}$ & $\begin{array}{c}\hat{\delta} \\
45\end{array}$ & 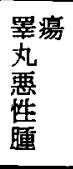 & 出 & \begin{tabular}{|c|} 
荇 \\
術当日 \\
2 \\
4 \\
7
\end{tabular} & $\begin{array}{l}3280 \\
2295 \\
2820 \\
3018 \\
3214\end{array}$ & $\begin{array}{r}100 \\
70 \\
86 \\
92 \\
98\end{array}$ & $\begin{array}{l}2540 \\
1727 \\
2032 \\
2413 \\
2489\end{array}$ & $\begin{array}{r}100 \\
68 \\
80 \\
95 \\
98\end{array}$ & $\begin{array}{l}77 \\
75 \\
72 \\
80 \\
77\end{array}$ & $\begin{array}{l}3642 \\
2258 \\
2732 \\
3205 \\
3423\end{array}$ & $\begin{array}{r}100 \\
62 \\
75 \\
88 \\
94\end{array}$ \\
\hline 54 & $\begin{array}{l}\text { 墄 } \\
\text { i }\end{array}$ & $\begin{array}{l}\text { 우 } \\
42\end{array}$ & 核 & $\begin{array}{l}\text { 根 } \\
\text { 治 } \\
\text { 手 } \\
\text { 術 }\end{array}$ & $\begin{array}{c}\text { 術前 } \\
\text { 背当日 } \\
2 \\
4 \\
7\end{array}$ & $\begin{array}{l}2350 \\
1152 \\
1598 \\
1857 \\
2138\end{array}$ & $\begin{array}{r}100 \\
49 \\
68 \\
79 \\
91\end{array}$ & $\begin{array}{r}1800 \\
828 \\
1206 \\
1458 \\
1620\end{array}$ & $\begin{array}{r}100 \\
46 \\
67 \\
81 \\
90\end{array}$ & $\begin{array}{l}77 \\
72 \\
75 \\
79 \\
76\end{array}$ & $\begin{array}{l}2562 \\
1076 \\
1614 \\
1895 \\
2178\end{array}$ & $\begin{array}{r}100 \\
42 \\
13 \\
74 \\
85\end{array}$ \\
\hline
\end{tabular}




\begin{tabular}{|c|c|c|c|c|c|c|c|c|c|c|c|c|}
\hline 55 & $\begin{array}{l}\text { 関 } \\
0 \\
\text { 武 } \\
0\end{array}$ & $\begin{array}{c}\hat{\delta} \\
33\end{array}$ & $\begin{array}{l}\text { 韧 } \\
\text { 核 }\end{array}$ & $\begin{array}{l}\text { 根 } \\
\text { 治 } \\
\text { 手 } \\
\text { 術 }\end{array}$ & $\begin{array}{c}\text { 前前 } \\
\text { 当日 } \\
2 \\
4 \\
7\end{array}$ & $\begin{array}{l}3740 \\
1945 \\
2730 \\
3142 \\
3590\end{array}$ & $\begin{array}{r}100 \\
52 \\
73 \\
84 \\
96\end{array}$ & $\begin{array}{l}3105 \\
1490 \\
2174 \\
2639 \\
3043\end{array}$ & $\begin{array}{r}100 \\
48 \\
70 \\
85 \\
98\end{array}$ & $\begin{array}{l}83 \\
77 \\
80 \\
84 \\
85\end{array}$ & $\begin{array}{l}4038 \\
1736 \\
2745 \\
3028 \\
3513\end{array}$ & $\begin{array}{r}100 \\
43 \\
68 \\
75 \\
87\end{array}$ \\
\hline 56 & $\begin{array}{l}\text { 中 } \\
\bigcirc \\
\text { 佐 }\end{array}$ & $\begin{array}{c}\delta \\
50\end{array}$ & 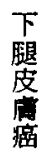 & $\begin{array}{l}\text { 試 } \\
\text { 験 } \\
\text { 切 } \\
\text { 除 }\end{array}$ & $\mid \begin{array}{c}\text { 術 前 } \\
\text { 当当日 } \\
2 \\
4 \\
7\end{array}$ & $\begin{array}{l}3950 \\
3200 \\
3555 \\
3900 \\
3870\end{array}$ & $\begin{array}{r}100 \\
81 \\
90 \\
99 \\
98\end{array}$ & $\begin{array}{l}3012 \\
2289 \\
2620 \\
2831 \\
3018\end{array}$ & $\begin{array}{r}100 \\
76 \\
87 \\
94 \\
100\end{array}$ & $\begin{array}{l}76 \\
72 \\
74 \\
73 \\
78\end{array}$ & $\begin{array}{l}4520 \\
2802 \\
3345 \\
3887 \\
4204\end{array}$ & $\begin{array}{r}100 \\
62 \\
74 \\
86 \\
93\end{array}$ \\
\hline
\end{tabular}

2. 成 績

䐈活量

手術前における胸部疾患10例（表 2）の肺活量の 平均值は $2300 \mathrm{cc}$ (\%v.c. の平均は65. $2 \%$ )で，上腹 部疾思 23 例（表 2) では2627cc（\%v.c.の平均值は $80.4 \%$ )，下腹部笂患15例（表 2 ）では $2874 \mathrm{cc}(\%$ v.c. の平均值は $86.0 \%$ ，四肢之の他疾患 8 例（表 2) では3712cc (\%v.c. の平均值は96\%) で, 胸部 疾思は手術前にすでに肺活量の低下を示し，上腹 部, 下腹部においてもやや低下がみられるが，四肢 疾患では正常の肺活量を示していた。術前值を 100 $\%$ こして, 術後の各時期の值を換算して各手術部位 別にその平均值について比較すると, 図 1 の如くで あった。

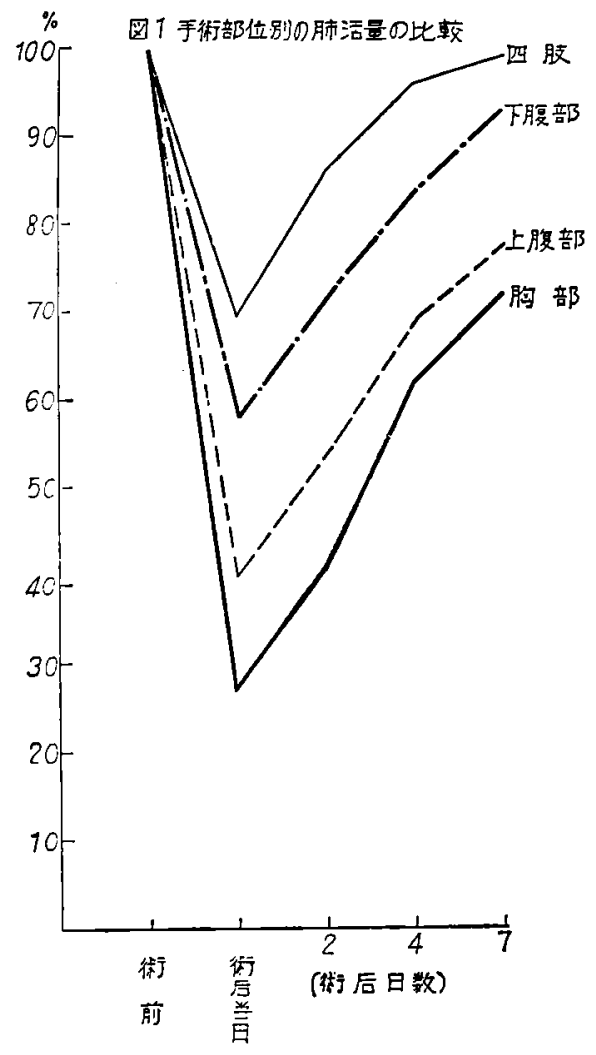

術後当日の肺活量は各手街部位とる著しく減少 し, 胸部手術では衍前値の $27 \%$ で最る著しく減少 し，ついで上腹部手術の $40 \%$ ，下腹部手郝の $58 \%$ で あって, 四肢手術その他では69\%で最も軽度であっ た。術後当日を最低として，術後 2 日，4 日と急速 亿烣復に向うが，術後 7 日においても，胸部手術で は街前值の73\%，上腹部手術では78\%を示し，なお 術前值には恢復しているいが，下腹部手術では 93 \%, 四肢その他手術では99\%で，ほとんど術前值に 坂復している。

時間肺活量 ( 1 秒量)

手術前における胸部疾患10例（表2）の1秒量の 平均值は1727CCで， 1 秒量正常籍团を2500 4000CG とすると ${ }^{18}$ 衍前にすでに 1 秒量の減少がみられる。

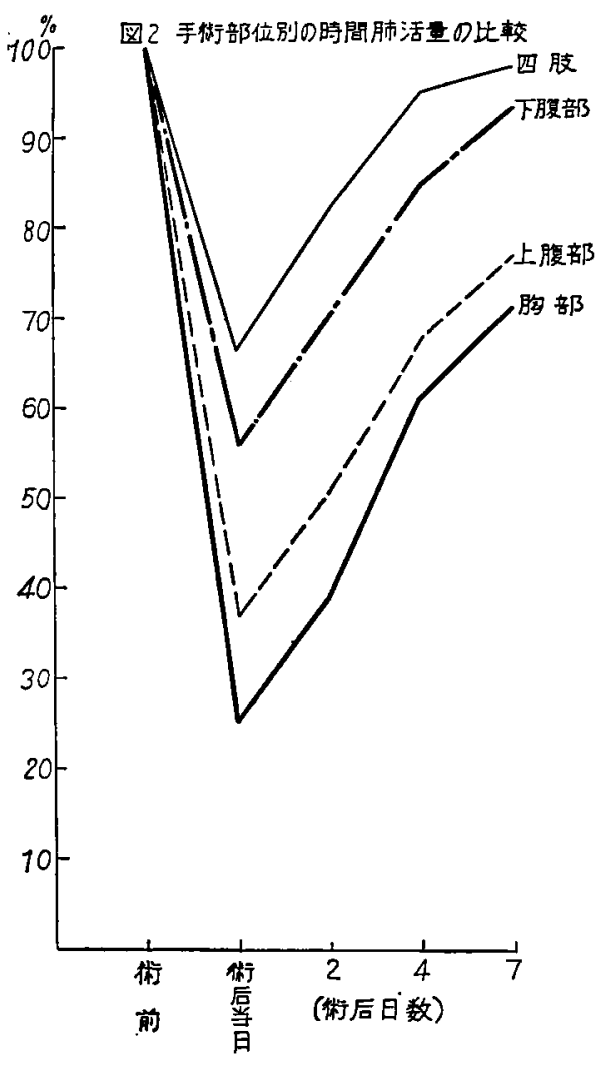


上腹部疾患23例（表 2）ではその平均が2030ccでや や低下し，下脂部疾患15例（表 2）では2407Cc，四 肢その他疾㭧の 8例（表 2）では3068ccで正常值を 示している。これら術前值を $100 \%$ とて術後の変 動を各手術部位別にをの平均值を比較すると図 2 の 如くである。

街後当日は 1 秒量は各手術部位とも著しく低下し て, 胸部手術では衍前值の $25 \%$ と最も低下し,つい で上腹部手術の37\%，下腹部手術の56\%であり，四 肢手術では66\%で最も軽度であった。衔後 2 日，術 後4 日には急速に咴復にむかうが，郝後 7 日におい ても，胸部手術は微前值の $71 \%$, 上腹部手術では77 \%でなお街前值には恢復していないが，下腹部手術 では93\%，四肢手術では98\%で，はとんど術前值に 饭復している。

\section{1 秒率}

手㭪前における胸部疾患10例(表 2)の 1 秒率の平 均值は73\%，上腹部手術23例(表 2 )では76\%，下腹 部手術例15例(表 2 )では83\%，四肢その他の疾患 8 例(表 2)では81\%，衙前すでに胸部智患では低下が みられ，下腹部，四肢その他の矣思でははは正常值 であった。とれらの術後の変動を各手術部位別にた の平均值について比較すると図 3 の如くである。

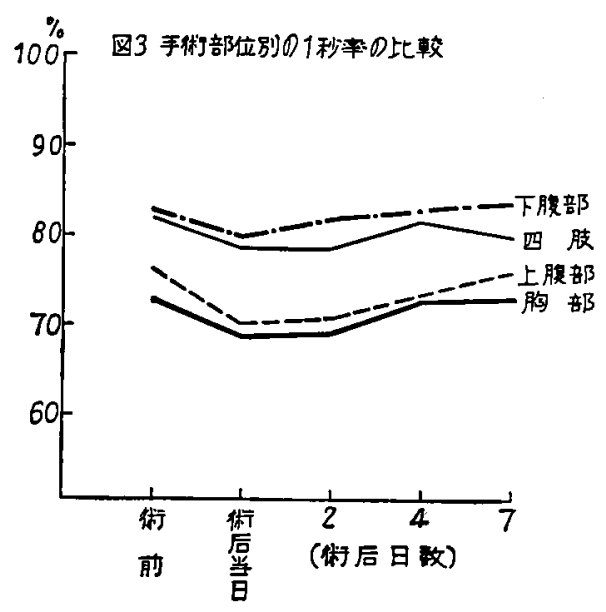

術後当日の 1 秒率㹥各手術部位とも低下して, 胸 部手街では69\%で最す低下し，ついで上腹部の 70 $\%$ ，下腹部手街の $80 \%$ ，四肢その他の手術では79\% であった。

術後当日を最低として, 政後 2 日以後には渐次饭 復にむかい，術後4 日には胸部手術では $73 \%$ 。上腹
部手術では74\%，下腹部手術では83\%，四肢その他 手術では $82 \%$ と各手術部位とも 1 秒率は術前值仿 復している。

\section{最大中間呼気速度 (M.M.F.)}

手術前における胸部疾思10例(表 2 )の M.M.F.の

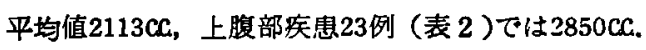
下腹部疾患15例（表 2）では3147cc，四肢その他の 疾患 8 例（表2）では4050ccで，胸部疾患では術前 すでに著しく低下し、上腹部, 下腹部, 四肢その他 の疾患では任とんど正常値を示している。術前値を 100\%として, 術後の変動を換算して各手術部位別 にその平均值を比較すると図 4 の如くである。

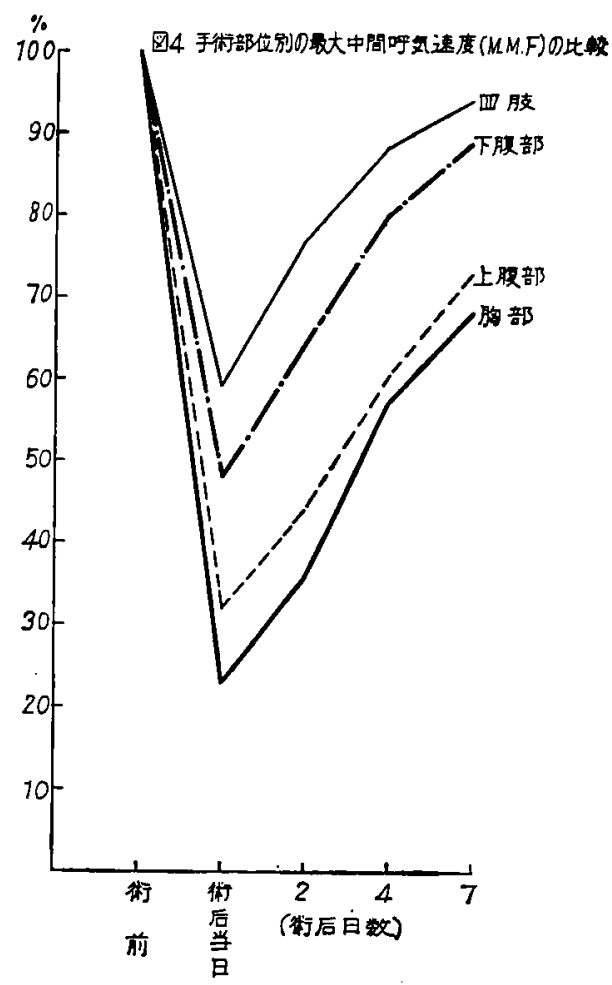

術後当日には M.M.F.は各手術部位とも著しく低 下して, 胸部手術では術前值の $23 \% て ゙$ 最す低下し, ついで上腹部手術の $32 \%$ ，下腹部手術の $48 \%$ ，四肢 その他の手術では59\%であった。郝後 2 日, 術後 4 日には急速に恢復にむかう。しかし術後 7 日におい ても胸部手術では術前值の68\%，上腹部手術では73 \%で、なわ術前值には饭復していないが，下腹部手 術では89\%，四肢その他の手郝では94\%ではとんど 街前值符团に欧復している。

3. 小 括 
外科的諸疾思の手術前後における肺換気機能の成 縝を一覧すると，肺活量， 1 秒量, M.M.F.ともに はとんど同し㑯向を示しているが，その変動は M.M.F、において最も著しい。胡機能と密接な関係の ある胸部疾患では術前すでに軽度ではあるが肺換気 機能の低下を示しており，上腹部疾患にもその影辢 はみられるが下腹部，四肢ての他の疾㭧でははとん ど正常筙囲内にある。乙れらの諸疾患の術後の経過 を追及して，各手衔部位別に肺活量，1秒量，M.M.F., 1 秒率について比較すると，ます術後当日に は総べての例が例外なく著しく低下するが，なかで も胸部手術が最も著明で，上腹部手術がてれについ でいる。下腹部手術, 四肢その他の手術では比較的 軽度である。術後当日急速に低下した茽活量，1秒 量，M.M.F. は術後 2 日上り恢復にむかい，術後 4 日から 7 日にかけて一段と俠復する。術後 7 日にお いても，胸部手術，上腹部手術では術前值にまで恢 復していないが, 下腹部手術, 四肢手術では, はと んど街前值範囲に恢復している。

前述の如く，手術部位による胡活量えの影䅉を比 較した場合に，各手術部位に含まれる症例の年令差

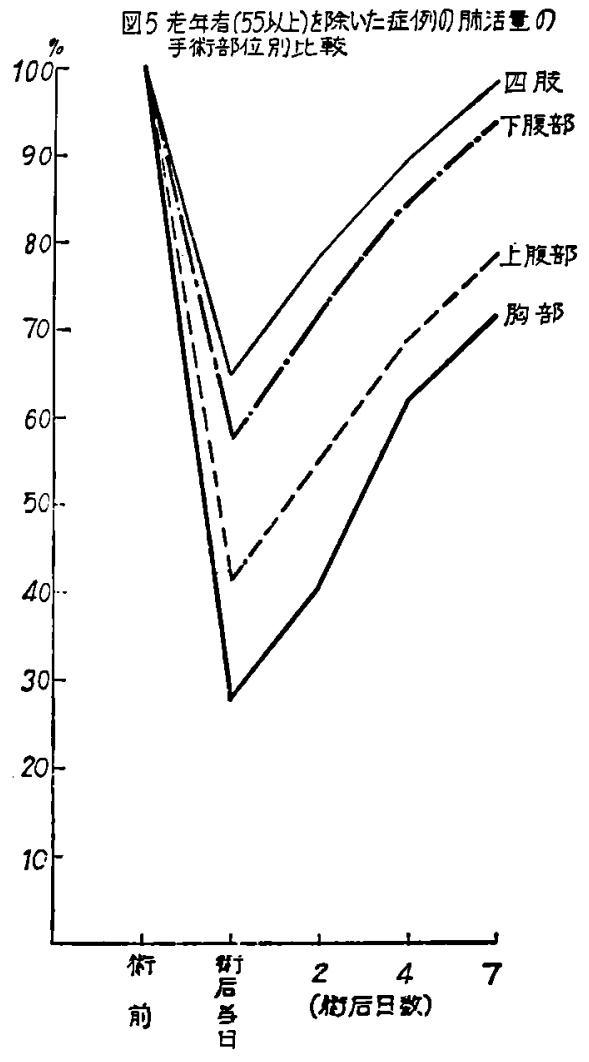

が手衙部位による差よりる大きく現れるのではない かという疑問について検討を行なった（総括ならび に考按を参照)。一般に年令が肺機能に影郎をおよ ばすと考えられる55才以上の老年者群を除外した症 例について比較を行ってみたところ（图 5），やは り前述の順位で胸部手術，上腹部手術にその影幚は 強く現れている。( 1 秒量, M.M.F.についても同様 のととがいる。)

1 秒率は前 3 者に比してその变動は軽度で術後当 日心各手衔部位とも低下す万が軽度で，胸部，上腹 部，下腹部，四肢手術の順で，術後 2 日より漸次饭 復し, 術後 4 日には各手術部位とも術前值を示して いる。

肺活量， 1 秒量，M.M.F. の術後の変動をみる と, 各手術部位とも, 術後 2 日から衡後 4 日かけて の灰復が著しいが，一般にての間に排気があること から，肺換気機能と術後鼓腸との関係もあるものと 推察される。

年令差による肺換気機能（肺活量， 1 秒率）その 影響をみるため，胃，十二指腸疾患に対する胃部分 切除術 9 例について，55才以上の老年者 4 例と，40 才以下の群の肺活量を比較すると図 6 の如く, 肺活 量は術後当日は両者とも著減するが, 術後 7 日で は，老年者群の平均は術前の72\%，40才以下の群の 平均は $80 \%$ と老年者群にやや低下が認められた。ま

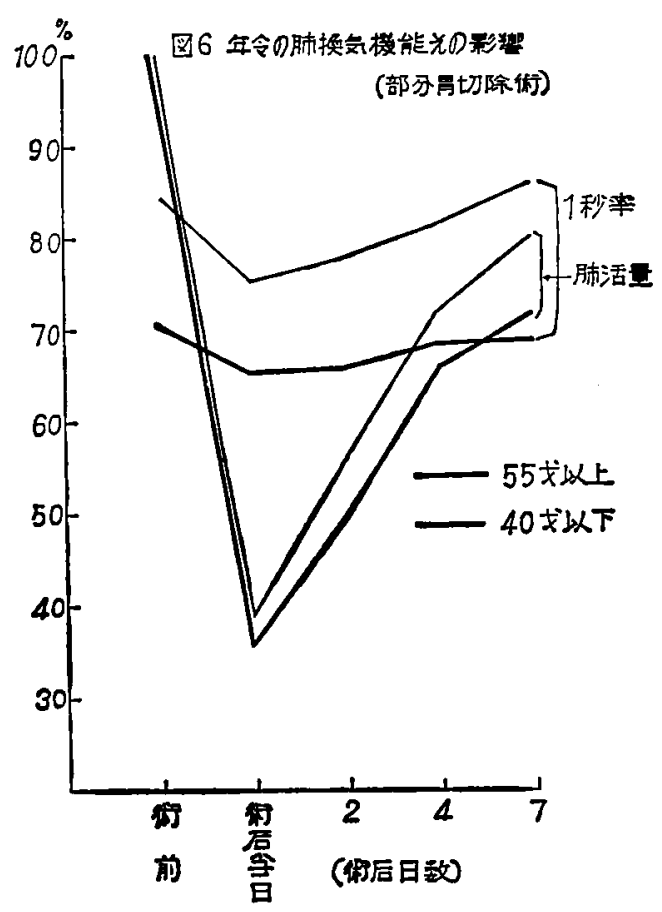


た 1 梨稗については，術前既に老年者群では低値を 示し, 術後 7 日では, 40才以下の群では術前值に欧 復するが老年者群ではまだ低下が認められた。

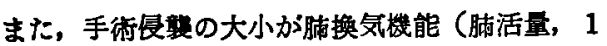
秒率）におよはすす影䅉をみるため, 图，十二指腸漬

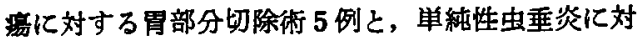
する虫垂切除術 6 例とを比較す万と図 7 の如く，肺 活量， 1 秒率は両者ともはは同一傾向を示し，肺活 量は術後当日に著しく減少し，術後 2 日より恢復に 向い，衍後 7 日では，虫垂切除術では殆んど術前值 を示すのにたいし，胃切除術ではなお饭復していな い。

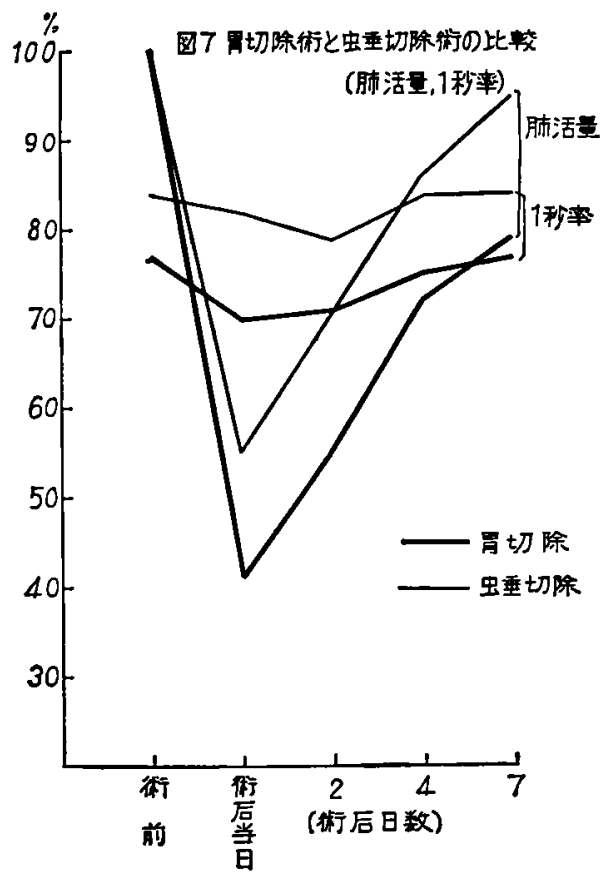

II 手術による動脈血ガス分圧ならびに pH の変勤

\section{1. 調查症例と研究方法}

当外科に入院し，手術を行なった患者71例を無選 択的にえらび検索した。疾患別と年龄別，性別は （表 3）の如くで, 術前, 術後当日, 術後 1 日, 街後 3 日, 術後 5 日, 術後 7 日に胸部 X線写真を前章と 同様の方法で撮影し，術後肺合併症の有無を知ると 同時に動脈血 $\mathrm{Po}_{2}, \mathrm{Pco}_{2}, \mathrm{pH}$ の則定を行ない, 手 街部位別に胸部手術, 上腹部手街, 下腹部手街, 四 肢その他手術に大別し比較検討を行なった。動脈血 の採血には，あらかしめ乾熱滅菌した 5 ccの注射器

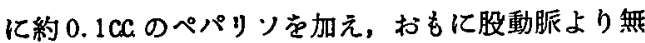
気的に採血し，採血後直ちに Beckman 社製ガス分 折器にて $\mathrm{Po}_{2}, \mathrm{Pco}_{c}, \mathrm{pH}$ の測定を行なった。採血

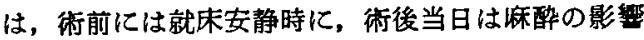
のとれた時期に，その他の時期でも努めて同一条件 下で行なった。

\section{2. 成 䋨}

胸部疾患 5 例，上腹部疾患 31例，下腹部疾患 24 例，四肢その他の突思11例（表 3）について，手術

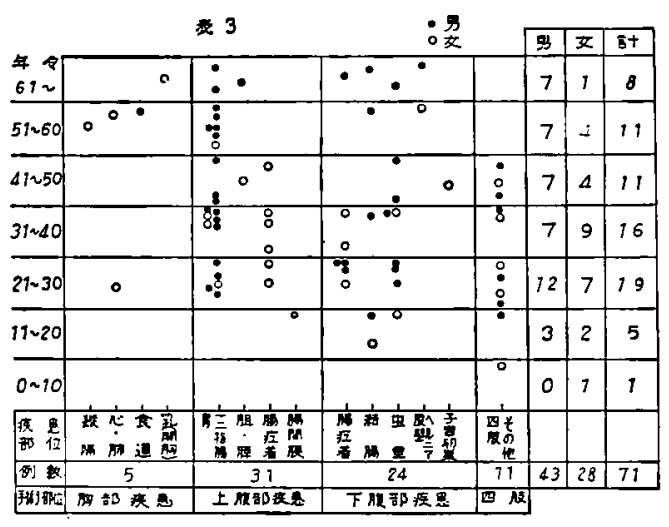

表

4

\begin{tabular}{|c|c|c|c|c|c|c|c|c|c|c|c|c|}
\hline 应 & 氏 & 名 & $\begin{array}{l}\text { 珄 } \\
\text { 年 }\end{array}$ & 診 断 & 術 & 検 查 & 街 前 & 術当日 & 1 & 3 & 5 & 7 \\
\hline 1 & 長○キ & $=0 x$ & $\begin{array}{c}\text { 우 } \\
58\end{array}$ & 肺 㾔 & 試験開胸 & $\begin{array}{l}\mathrm{Po}_{2} \\
\mathrm{PcO}_{2} \\
\mathrm{pH}\end{array}$ & $\begin{array}{r}85 \\
38 \\
7.36\end{array}$ & $\begin{array}{r}71 \\
40 \\
7.36\end{array}$ & $\begin{array}{r}76 \\
46 \\
7.34\end{array}$ & $\begin{array}{r}80 \\
38 \\
7.36\end{array}$ & $\begin{array}{r}86 \\
36 \\
7.36\end{array}$ & $\begin{array}{r}82 \\
34 \\
7.37\end{array}$ \\
\hline 2 & 小O & $\Sigma 0$ & $\begin{array}{c}\text { 우 } \\
56\end{array}$ & $\begin{array}{l}\text { 縦隔皮 } \\
\text { 様堡稙 }\end{array}$ & 摘 & $\begin{array}{l}\mathrm{Po}_{2} \\
\mathrm{PcO}_{2} \\
\mathrm{pH}\end{array}$ & $\begin{array}{r}78 \\
33 \\
7.41\end{array}$ & $\begin{array}{r}68 \\
38 \\
7.40\end{array}$ & $\begin{array}{r}65 \\
40 \\
7.37\end{array}$ & $\begin{array}{r}70 \\
43 \\
7.35\end{array}$ & $\begin{array}{r}68 \\
42 \\
7.36\end{array}$ & $\begin{array}{r}72 \\
38 \\
7.37\end{array}$ \\
\hline 3 & 宮O & 梅 $\mathrm{O}$ & $\begin{array}{l}\text { 우 } \\
65\end{array}$ & $\begin{array}{l}\text { 乳癌胸胸 } \\
\text { 熟転移 }\end{array}$ & 切除植皮 & $\begin{array}{l}\mathrm{Po}_{2} \\
\mathrm{PcO}_{2} \\
\mathrm{pH}\end{array}$ & $\begin{array}{r}74 \\
40 \\
7.38\end{array}$ & $\begin{array}{r}72 \\
46 \\
7.35\end{array}$ & $\begin{array}{r}(61) \\
(52) \\
(7.22)\end{array}$ & \multicolumn{3}{|c|}{ 多 } \\
\hline
\end{tabular}




\begin{tabular}{|c|c|c|c|c|c|c|c|c|c|c|c|}
\hline 4 & 慢O 清O & $\begin{array}{c}\hat{\jmath} \\
58\end{array}$ & 食道病 & 試匼 䦎胸 & $\begin{array}{l}\mathrm{Po}_{2} \\
\mathrm{PcO}_{2} \\
\mathrm{pH}\end{array}$ & $\begin{array}{r}86 \\
36 \\
7.36\end{array}$ & $\begin{array}{r}70 \\
45 \\
7.34\end{array}$ & $\begin{array}{r}68 \\
45 \\
7.34\end{array}$ & $\begin{array}{r}72 \\
49 \\
7.35\end{array}$ & $\begin{array}{r}76 \\
34 \\
7.37\end{array}$ & $\begin{array}{r}72 \\
38 \\
7.36\end{array}$ \\
\hline 5 & 渡 0 楖O & $\begin{array}{l}\text { 우 } \\
24\end{array}$ & $\begin{array}{l}\text { 肺動脈 } \\
\text { 狭窄症 }\end{array}$ & 根治手術 & $\begin{array}{l}\mathrm{Po}_{2} \\
\mathrm{PcO}_{2} \\
\mathrm{pH}\end{array}$ & $\begin{array}{r}78 \\
39 \\
7.34\end{array}$ & $\begin{array}{r}73 \\
34 \\
7.34\end{array}$ & $\begin{array}{r}(40) \\
(62) \\
(7.20)\end{array}$ & \multicolumn{3}{|c|}{ 死 } \\
\hline 6 & 野O & $\begin{array}{c}\delta \\
55\end{array}$ & 胃濽瑒 & 疽切除 B I & $\begin{array}{l}\mathrm{Po}_{2} \\
\mathrm{PcO}_{2} \\
\mathrm{pH}\end{array}$ & $\begin{array}{r}82 \\
37 \\
7.38\end{array}$ & $\begin{array}{r}84 \\
40 \\
7.37\end{array}$ & $\begin{array}{r}82 \\
36 \\
7.38\end{array}$ & $\begin{array}{r}80 \\
37 \\
7.38\end{array}$ & $\begin{array}{r}83 \\
34 \\
7.40\end{array}$ & $\begin{array}{r}86 \\
35 \\
7.41\end{array}$ \\
\hline 7 & 北O 蟥O & $\begin{array}{l}\hat{\sigma} \\
40\end{array}$ & 胃濽懪 & 胃切除 B I & $\begin{array}{l}\mathrm{Po}_{2} \\
\mathrm{PcO}_{2} \\
\mathrm{pH}\end{array}$ & $\begin{array}{r}80 \\
40 \\
7.38\end{array}$ & $\begin{array}{r}93 \\
36 \\
7.40\end{array}$ & $\begin{array}{r}76 \\
42 \\
7.39\end{array}$ & $\begin{array}{r}78 \\
40 \\
7.37\end{array}$ & $\begin{array}{r}72 \\
40 \\
7.37\end{array}$ & $\begin{array}{r}84 \\
30 \\
7.35\end{array}$ \\
\hline 8 & 原O 静O & $\begin{array}{c}\text { 운 } \\
25\end{array}$ & 周溃㻛 & 胃切除 B I & $\begin{array}{l}\mathrm{Po}_{2} \\
\mathrm{Pco}_{2} \\
\mathrm{pH}\end{array}$ & $\begin{array}{r}92 \\
36 \\
7.38\end{array}$ & $\begin{array}{r}87 \\
43 \\
7.32\end{array}$ & $\begin{array}{r}80 \\
32 \\
7.34\end{array}$ & $\begin{array}{r}84 \\
40 \\
7.33\end{array}$ & $\begin{array}{r}78 \\
38 \\
7.37\end{array}$ & $\begin{array}{r}86 \\
40 \\
7.38\end{array}$ \\
\hline 9 & 中O 国O & $\begin{array}{c}\hat{\sigma} \\
50\end{array}$ & 胃溃場 & 胃切除 B I & $\begin{array}{l}\mathrm{Po}_{2} \\
\mathrm{Pcc}_{2} \\
\mathrm{pH}\end{array}$ & $\begin{array}{r}86 \\
40 \\
7.43\end{array}$ & $\begin{array}{r}75 \\
36 \\
7.36\end{array}$ & $\begin{array}{r}73 \\
34 \\
7.38\end{array}$ & $\begin{array}{r}80 \\
36 \\
7.35\end{array}$ & $\begin{array}{r}84 \\
36 \\
7.37\end{array}$ & $\begin{array}{r}84 \\
36 \\
7.39\end{array}$ \\
\hline 10 & 宇○木吉○ & $\begin{array}{c}\delta \\
42\end{array}$ & 胃漬第 & 胃切除 B I & $\begin{array}{l}\mathrm{Po}_{2} \\
\mathrm{PcO}_{2} \\
\mathrm{pH}\end{array}$ & $\begin{array}{r}100 \\
43 \\
7.37\end{array}$ & $\begin{array}{r}95 \\
42 \\
7.35\end{array}$ & $\begin{array}{r}84 \\
44 \\
7.34\end{array}$ & $\begin{array}{r}85 \\
43 \\
7.36\end{array}$ & $\begin{array}{r}82 \\
40 \\
7.36\end{array}$ & $\begin{array}{r}83 \\
41 \\
7.36\end{array}$ \\
\hline 11 & 伊O 裕O & $\begin{array}{c}\delta \\
41\end{array}$ & 胃漬瘍 & $\begin{array}{l}\text { 胃切除B I } \\
\text { 虫垂切除 }\end{array}$ & $\begin{array}{l}\mathrm{Po}_{2} \\
\mathrm{PcO}_{2} \\
\mathrm{pH}\end{array}$ & $\begin{array}{r}88 \\
42 \\
7.36\end{array}$ & $\begin{array}{r}80 \\
36 \\
7.34\end{array}$ & $\begin{array}{r}70 \\
34 \\
7.36\end{array}$ & $\begin{array}{r}80 \\
36 \\
7.36\end{array}$ & $\begin{array}{r}70 \\
38 \\
7.38\end{array}$ & $\begin{array}{r}81 \\
39 \\
7.41\end{array}$ \\
\hline 12 & 秀O & $\begin{array}{c}\hat{\delta} \\
23\end{array}$ & 胃漬痬 & 胃切除 B I & $\begin{array}{l}\mathrm{Po}_{2} \\
\mathrm{Pco}_{2} \\
\mathrm{pH}\end{array}$ & $\begin{array}{r}85 \\
45 \\
7.40\end{array}$ & $\begin{array}{r}70 \\
35 \\
7.35\end{array}$ & $\begin{array}{r}76 \\
33 \\
7.36\end{array}$ & $\begin{array}{r}77 \\
40 \\
7.39\end{array}$ & $\begin{array}{r}83 \\
42 \\
7.38\end{array}$ & $\begin{array}{r}84 \\
37 \\
7.39\end{array}$ \\
\hline 13 & 小O 昌O & $\begin{array}{c}\hat{\delta} \\
38\end{array}$ & 胃謴場 & $\begin{array}{l}\text { 胃切除B I } \\
\text { 虫金切除 }\end{array}$ & $\begin{array}{l}\mathrm{Po}_{2} \\
\mathrm{PcO}_{2} \\
\mathrm{pH}\end{array}$ & $\begin{array}{r}86 \\
42 \\
7.42\end{array}$ & $\begin{array}{r}75 \\
53 \\
7.40\end{array}$ & $\begin{array}{r}73 \\
45 \\
7.38\end{array}$ & $\begin{array}{r}77 \\
40 \\
7.39\end{array}$ & $\begin{array}{r}82 \\
42 \\
7.38\end{array}$ & $\begin{array}{r}82 \\
42 \\
7.37\end{array}$ \\
\hline 14 & 佐O & $\begin{array}{c}\delta \\
55\end{array}$ & 胃溃钽 & 胃切除 B I & $\begin{array}{l}\mathrm{Po}_{2} \\
\mathrm{PcO}_{2} \\
\mathrm{pH}\end{array}$ & $\begin{array}{r}70 \\
36 \\
7.40\end{array}$ & $\begin{array}{r}65 \\
44 \\
7.38\end{array}$ & $\begin{array}{r}63 \\
44 \\
7.38\end{array}$ & $\begin{array}{r}72 \\
48 \\
7.36\end{array}$ & $\begin{array}{r}70 \\
45 \\
7.37\end{array}$ & $\begin{array}{r}74 \\
46 \\
7.36\end{array}$ \\
\hline 15 & 森O 静O & $\begin{array}{r}\text { 우 } \\
52\end{array}$ & 胃謴晹 & 胃切除 B I & $\begin{array}{l}\mathrm{Po}_{2} \\
\mathrm{PcO}_{2} \\
\mathrm{pH}\end{array}$ & $\begin{array}{r}80 \\
34 \\
7.40\end{array}$ & $\begin{array}{r}72 \\
42 \\
7.35\end{array}$ & $\begin{array}{r}60 \\
38 \\
7.30\end{array}$ & $\begin{array}{r}67 \\
36 \\
7.30\end{array}$ & $\begin{array}{r}66 \\
38 \\
7.36\end{array}$ & $\begin{array}{r}70 \\
40 \\
7.50\end{array}$ \\
\hline 16 & 突O 倉O & $\begin{array}{l}5 \\
24\end{array}$ & 慢性胃咨 & 胃切除 B I & $\begin{array}{l}\mathrm{Po}_{2} \\
\mathrm{PcO}_{2} \\
\mathrm{pH}\end{array}$ & $\begin{array}{r}90 \\
34 \\
7.38\end{array}$ & $\begin{array}{r}104 \\
38 \\
7.41\end{array}$ & $\begin{array}{r}78 \\
45 \\
7.40\end{array}$ & $\begin{array}{r}82 \\
46 \\
7.41\end{array}$ & $\begin{array}{r}74 \\
47 \\
7.40\end{array}$ & $\begin{array}{r}78 \\
34 \\
7.42\end{array}$ \\
\hline 17 & 新O $ッ$ & \begin{tabular}{r|} 
우 \\
45
\end{tabular} & $\mid$ & $\begin{array}{l}\text { 賁切除 B I } \\
\text { 摘出 }\end{array}$ & $\begin{array}{l}\mathrm{Po}_{2} \\
\mathrm{PcO}_{2} \\
\mathrm{pH}\end{array}$ & $\begin{array}{r}75 \\
42 \\
7.38\end{array}$ & $\begin{array}{r}70 \\
32 \\
7.38\end{array}$ & $\begin{array}{r}68 \\
32 \\
7.36\end{array}$ & $\begin{array}{r}76 \\
36 \\
7.36\end{array}$ & $\begin{array}{r}73 \\
44 \\
7.41\end{array}$ & $\begin{array}{r}75 \\
38 \\
7.36\end{array}$ \\
\hline 18 & 湾O & $\begin{array}{c}\hat{\delta} \\
30\end{array}$ & 南二措 & $\begin{array}{l}\text { 胃切除B I } \\
\text { 虫垂切除 }\end{array}$ & $\begin{array}{l}\mathrm{Po}_{2} \\
\mathrm{PcO}_{2} \\
\mathrm{pH}\end{array}$ & $\begin{array}{r}80 \\
43 \\
7.42\end{array}$ & $\begin{array}{r}70 \\
40 \\
7.37\end{array}$ & $\begin{array}{r}70 \\
38 \\
7.40\end{array}$ & $\begin{array}{r}78 \\
34 \\
7.38\end{array}$ & $\begin{array}{r}80 \\
32 \\
7.38\end{array}$ & $\begin{array}{r}90 \\
36 \\
7.36\end{array}$ \\
\hline 19 & 梅 $\bigcirc$ 美 $\mathrm{O}$ & $\begin{array}{c}\text { 우 } \\
37\end{array}$ & 十二指 & 胃切除 B I & $\begin{array}{l}\mathrm{Po}^{2} \\
\mathrm{Pco}_{2} \\
\mathrm{pH}\end{array}$ & $\begin{array}{r}72 \\
42 \\
7.40\end{array}$ & $\begin{array}{r}65 \\
37 \\
7.38\end{array}$ & $\begin{array}{r}62 \\
33 \\
7.38\end{array}$ & $\begin{array}{r}72 \\
36 \\
7.36\end{array}$ & $\begin{array}{r}74 \\
38 \\
7.36\end{array}$ & $\begin{array}{r}72 \\
36 \\
7.37\end{array}$ \\
\hline 20 & 遠O 英O & $\begin{array}{c}\delta \\
26\end{array}$ & $\begin{array}{l}\text { 胃はん } \\
\text { 寸う叐 }\end{array}$ & 胃 全 摘 & $\begin{array}{l}\mathrm{Po}_{2} \\
\mathrm{PcO}_{2} \\
\mathrm{pH}\end{array}$ & $\begin{array}{r}84 \\
45 \\
7.40\end{array}$ & $\begin{array}{r}100 \\
36 \\
7.31\end{array}$ & $\begin{array}{r}70 \\
32 \\
7.42\end{array}$ & $\begin{array}{r}68 \\
38 \\
7.42\end{array}$ & $\begin{array}{r}67 \\
42 \\
7.41\end{array}$ & $\begin{array}{r}75 \\
42 \\
7.39\end{array}$ \\
\hline 21 & 長O川金O & $\begin{array}{c}\text { 今。 } \\
54\end{array}$ & 胃 病 & $\begin{array}{l}\text { 胃切除 B I } \\
\text { 虫菲切除 }\end{array}$ & $\begin{array}{l}\mathrm{Po}_{2} \\
\mathrm{Pco}_{2} \\
\mathrm{pH}\end{array}$ & $\begin{array}{r}100 \\
32 \\
7.39\end{array}$ & $\begin{array}{r}67 \\
42 \\
7.37\end{array}$ & $\begin{array}{r}60 \\
35 \\
7.38\end{array}$ & $\begin{array}{r}60 \\
32 \\
7.36\end{array}$ & $\begin{array}{r}77 \\
37 \\
7.38\end{array}$ & $\begin{array}{r}74 \\
36 \\
7.40\end{array}$ \\
\hline
\end{tabular}




\begin{tabular}{|c|c|c|c|c|c|c|c|c|c|c|c|}
\hline 22 & 湯O & $\begin{array}{l}\delta \\
60\end{array}$ & 胃 瘦 & 胃切除 B I & $\begin{array}{l}\mathrm{Po}_{2} \\
\mathrm{PcO}_{2} \\
\mathrm{pH}\end{array}$ & $\begin{array}{r}85 \\
33 \\
7.40\end{array}$ & $\begin{array}{r}70 \\
40 \\
7.35\end{array}$ & $\begin{array}{r}76 \\
38 \\
7.30\end{array}$ & $\begin{array}{r}77 \\
36 \\
7.30\end{array}$ & $\begin{array}{r}82 \\
40 \\
7.41\end{array}$ & $\begin{array}{r}80 \\
37 \\
7.38\end{array}$ \\
\hline 23 & 中O 英O & $\begin{array}{c}\hat{\delta} \\
58\end{array}$ & 胃 癌 & $\begin{array}{l}\text { 胃切除B I } \\
\text { 虫垂切除 }\end{array}$ & $\begin{array}{l}\mathrm{Po}_{2} \\
\mathrm{PcO}_{2} \\
\mathrm{pH}\end{array}$ & $\begin{array}{r}86 \\
36 \\
7.37\end{array}$ & $\begin{array}{r}80 \\
43 \\
7.36\end{array}$ & $\begin{array}{r}70 \\
43 \\
7.34\end{array}$ & $\begin{array}{r}80 \\
47 \\
7.36\end{array}$ & $\begin{array}{r}70 \\
45 \\
7.38\end{array}$ & $\begin{array}{r}71 \\
48 \\
7.41\end{array}$ \\
\hline 24 & 武O 二O & $\begin{array}{l}\hat{\delta} \\
68\end{array}$ & 胃 瘦 & 胃切除 B II & $\begin{array}{l}\mathrm{Po}_{2} \\
\mathrm{PcO}_{2} \\
\mathrm{pH}\end{array}$ & $\begin{array}{r}80 \\
40 \\
7.38\end{array}$ & $\begin{array}{r}72 \\
45 \\
7.30\end{array}$ & $\begin{array}{r}60 \\
40 \\
7.36\end{array}$ & $\begin{array}{r}68 \\
35 \\
7.39\end{array}$ & $\begin{array}{r}67 \\
32 \\
7.38\end{array}$ & $\begin{array}{r}70 \\
32 \\
7.37\end{array}$ \\
\hline 25 & 五○藏大O & $\begin{array}{l}\hat{\sigma} \\
40\end{array}$ & 胃 癌 & 胃切除 B I & $\begin{array}{l}\mathrm{Po}_{2} \\
\mathrm{PcO}_{2} \\
\mathrm{pH}\end{array}$ & $\begin{array}{r}84 \\
42 \\
7.36\end{array}$ & $\begin{array}{r}70 \\
36 \\
7.34\end{array}$ & $\begin{array}{r}70 \\
34 \\
7.36\end{array}$ & $\begin{array}{r}72 \\
36 \\
7.36\end{array}$ & $\begin{array}{r}76 \\
38 \\
7.38\end{array}$ & $\begin{array}{r}72 \\
39 \\
7.40\end{array}$ \\
\hline 26 & 今○愛 $\mathrm{OO}$ & $\begin{array}{l}\delta \\
63\end{array}$ & 青 癌 & 胃腸 吻 合 & $\begin{array}{l}\mathrm{Po}_{2} \\
\mathrm{PcO}_{2} \\
\mathrm{pH}\end{array}$ & $\begin{array}{r}100 \\
34 \\
7.39\end{array}$ & $\begin{array}{r}66 \\
38 \\
7.37\end{array}$ & $\begin{array}{r}59 \\
46 \\
7.38\end{array}$ & $\begin{array}{r}60 \\
47 \\
7.36\end{array}$ & $\begin{array}{r}64 \\
48 \\
7.38\end{array}$ & $\begin{array}{r}75 \\
35 \\
7.40\end{array}$ \\
\hline 27 & 松OとOO & $\begin{array}{c}\text { 우 } \\
38\end{array}$ & 胃 癌 & $\begin{array}{l}\text { 罢切除 B I } \\
\text { 瘦 }\end{array}$ & $\begin{array}{l}\mathrm{Po}_{2} \\
\mathrm{PcO}_{2} \\
\mathrm{pH}\end{array}$ & $\begin{array}{r}80 \\
34 \\
7.37\end{array}$ & $\begin{array}{r}72 \\
40 \\
7.32\end{array}$ & $\begin{array}{r}60 \\
38 \\
7.36\end{array}$ & $\begin{array}{r}67 \\
36 \\
7.39\end{array}$ & $\begin{array}{r}66 \\
37 \\
7.38\end{array}$ & $\begin{array}{r}70 \\
40 \\
7.37\end{array}$ \\
\hline 28 & 加O 隆O & $\begin{array}{l}\delta \\
38\end{array}$ & 胃 癌 & 胃腸吻合 & $\begin{array}{l}\mathrm{Po}_{2} \\
\mathrm{PcO}_{2} \\
\mathrm{pH}\end{array}$ & $\begin{array}{r}75 \\
45 \\
7.38\end{array}$ & $\begin{array}{r}70 \\
45 \\
7.38\end{array}$ & $\begin{array}{r}67 \\
35 \\
7.34\end{array}$ & $\begin{array}{r}75 \\
35 \\
7.36\end{array}$ & $\begin{array}{r}72 \\
36 \\
7.36\end{array}$ & $\begin{array}{r}72 \\
36 \\
7.41\end{array}$ \\
\hline 29 & 越O 富O & $\begin{array}{c}\text { 우 } \\
32\end{array}$ & 腸霍着 & 腸 切 除 & $\begin{array}{l}\mathrm{Po}_{2} \\
\mathrm{PcO}_{2} \\
\mathrm{pH}\end{array}$ & $\begin{array}{r}86 \\
41 \\
7.36\end{array}$ & $\begin{array}{r}84 \\
40 \\
7.36\end{array}$ & $\begin{array}{r}85 \\
37 \\
7.34\end{array}$ & $\begin{array}{r}82 \\
38 \\
7.30\end{array}$ & $\begin{array}{r}83 \\
38 \\
7.36\end{array}$ & $\begin{array}{r}86 \\
40 \\
7.38\end{array}$ \\
\hline 30 & 藤OUOO & $\begin{array}{r}\text { 우 } \\
25\end{array}$ & 吻合病 & 小腸 切 除 & $\begin{array}{l}\mathrm{Po}_{2} \\
\mathrm{PCO}_{2} \\
\mathrm{pH}\end{array}$ & $\begin{array}{r}80 \\
36 \\
7.38\end{array}$ & $\begin{array}{r}76 \\
40 \\
7.40\end{array}$ & $\begin{array}{r}74 \\
41 \\
7.36\end{array}$ & $\begin{array}{r}76 \\
38 \\
7.39\end{array}$ & $\begin{array}{r}78 \\
40 \\
7.41\end{array}$ & $\begin{array}{r}80 \\
41 \\
7.38\end{array}$ \\
\hline 31 & 谷О八ОО & $\begin{array}{c}\text { 우 } \\
28\end{array}$ & 腸磨着 & 小腸 切 除 & $\begin{array}{l}\mathrm{Po}_{2} \\
\mathrm{PcO}_{2} \\
\mathrm{pH}\end{array}$ & $\begin{array}{r}86 \\
38 \\
7.34\end{array}$ & $\begin{array}{r}78 \\
44 \\
7.30\end{array}$ & $\begin{array}{r}78 \\
40 \\
7.31\end{array}$ & $\begin{array}{r}81 \\
34 \\
7.40\end{array}$ & $\begin{array}{r}88 \\
34 \\
7.38\end{array}$ & $\begin{array}{r}92 \\
36 \\
7.39\end{array}$ \\
\hline 32 & 山O & $\begin{array}{c}\hat{\delta} \\
67\end{array}$ & 腸軸捻転 & $\begin{array}{l}\text { 結腸切除 } \\
人 工 \text { 工䀴 }\end{array}$ & $\begin{array}{l}\mathrm{Po}_{2} \\
\mathrm{PcO}_{2} \\
\mathrm{pH}\end{array}$ & $\begin{array}{r}76 \\
42 \\
7.26\end{array}$ & $\begin{array}{r}72 \\
45 \\
7.24\end{array}$ & \multicolumn{4}{|c|}{ 死 } \\
\hline 33 & 井O 幸O & $\begin{array}{l}\text { ㅇ } \\
39\end{array}$ & イレウス & 小腸 切 除 & $\begin{array}{l}\mathrm{Po}_{2} \\
\mathrm{Pco}_{2} \\
\mathrm{pH}\end{array}$ & $\begin{array}{r}82 \\
36 \\
7.39\end{array}$ & $\begin{array}{r}85 \\
40 \\
7.40\end{array}$ & $\begin{array}{r}80 \\
37 \\
7.40\end{array}$ & $\begin{array}{r}78 \\
36 \\
7.38\end{array}$ & $\begin{array}{r}82 \\
34 \\
7.36\end{array}$ & $\begin{array}{r}79 \\
35 \\
7.36\end{array}$ \\
\hline 34 & 福O 信O & $\begin{array}{l}\hat{8} \\
38\end{array}$ & 吻合病 & $\begin{array}{l}\text { 右半 側 } \\
\text { 結腸切除 }\end{array}$ & $\begin{array}{l}\mathrm{Po}_{2} \\
\mathrm{Pco}_{2} \\
\mathrm{pH}\end{array}$ & $\begin{array}{r}82 \\
34 \\
7.36\end{array}$ & $\begin{array}{r}90 \\
42 \\
7.30\end{array}$ & $\begin{array}{r}73 \\
43 \\
7.31\end{array}$ & $\begin{array}{r}80 \\
42 \\
7.33\end{array}$ & $\begin{array}{r}83 \\
38 \\
7.33\end{array}$ & $\begin{array}{r}81 \\
36 \\
7.32\end{array}$ \\
\hline 35 & 曾○○ク○ & $\begin{array}{l}9 \\
47\end{array}$ & 腸療着症 & 瀮着剩離 & $\begin{array}{l}\mathrm{Po}_{2} \\
\mathrm{PcO}_{2} \\
\mathrm{pH}\end{array}$ & $\begin{array}{r}73 \\
30 \\
7.41\end{array}$ & $\begin{array}{r}60 \\
48 \\
7.39\end{array}$ & $\begin{array}{r}63 \\
36 \\
7.39\end{array}$ & $\begin{array}{r}72 \\
33 \\
7.37\end{array}$ & $\begin{array}{r}83 \\
36 \\
7.38\end{array}$ & $\begin{array}{r}90 \\
35 \\
7.38\end{array}$ \\
\hline 36 & 吉○ あ○ & $\begin{array}{l}\text { ㅇ } \\
37\end{array}$ & 晹底着症 & $\begin{array}{l}\text { 囷腸横行結 } \\
\text { 腸 吻 合 }\end{array}$ & $\begin{array}{l}\mathrm{Po}_{2} \\
\mathrm{PcO}_{2} \\
\mathrm{pH}\end{array}$ & $\begin{array}{r}100 \\
38 \\
7.40\end{array}$ & $\begin{array}{r}88 \\
36 \\
7.32 \\
\end{array}$ & $\begin{array}{r}80 \\
40 \\
7.41 \\
\end{array}$ & $\begin{array}{r}77 \\
44 \\
7.35\end{array}$ & $\begin{array}{r}80 \\
37 \\
7.40 \\
\end{array}$ & $\begin{array}{r}84 \\
35 \\
7.36 \\
\end{array}$ \\
\hline 37 & 田○ 春○ & $\begin{array}{l}\text { 우 } \\
38\end{array}$ & $\begin{array}{l}\text { 腸壁ヘル } \\
=\text { 学 } \\
\text { 腸 着 }\end{array}$ & 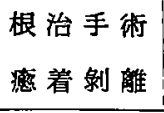 & $\begin{array}{l}\mathrm{Po}_{2} \\
\mathrm{PcO}_{2} \\
\mathrm{pH}\end{array}$ & $\begin{array}{r}87 \\
43 \\
7.38 \\
\end{array}$ & $\begin{array}{r}81 \\
40 \\
7.36 \\
\end{array}$ & $\begin{array}{r}86 \\
42 \\
7.32\end{array}$ & $\begin{array}{r}81 \\
43 \\
7.36\end{array}$ & $\begin{array}{r}83 \\
38 \\
7.32 \\
\end{array}$ & $\begin{array}{r}92 \\
36 \\
7.36\end{array}$ \\
\hline 38 & 森○安○○ & $\begin{array}{l}\uparrow \\
65\end{array}$ & 腸癩着症 & $\begin{array}{l}\text { 腸 } \\
\text { 腸 } \\
\text { 合 }\end{array}$ & $\begin{array}{l}\mathrm{Po}_{2} \\
\mathrm{PcO}_{2} \\
\mathrm{pH}\end{array}$ & $\begin{array}{r}74 \\
37 \\
7.40\end{array}$ & $\begin{array}{r}70 \\
43 \\
7.38 \\
\end{array}$ & $\begin{array}{r}67 \\
43 \\
7.38 \\
\end{array}$ & $\begin{array}{r}77 \\
41 \\
7.34 \\
\end{array}$ & $\begin{array}{r}74 \\
43 \\
7.35\end{array}$ & $\begin{array}{r}70 \\
45 \\
7.40\end{array}$ \\
\hline 39 & 武O 嘉O & $\begin{array}{l}\hat{\sigma} \\
29\end{array}$ & 腸而着 & $\begin{array}{l}\text { 䞤腸横行 } \\
\text { 結腸吻合 }\end{array}$ & $\begin{array}{l}\mathrm{Po}_{2} \\
\mathrm{Pco}_{2} \\
\mathrm{pH}\end{array}$ & $\begin{array}{r}78 \\
40 \\
7.37\end{array}$ & $\begin{array}{r}80 \\
41 \\
7.30\end{array}$ & $\begin{array}{r}78 \\
34 \\
7.28\end{array}$ & $\begin{array}{r}73 \\
40 \\
7.30\end{array}$ & $\begin{array}{r}68 \\
35 \\
7.36\end{array}$ & $\begin{array}{r}75 \\
37 \\
7.38\end{array}$ \\
\hline
\end{tabular}




\begin{tabular}{|c|c|c|c|c|c|c|c|c|c|c|c|}
\hline 40 & 土○满OO & $\begin{array}{l}\text { 우 } \\
32\end{array}$ & 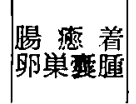 & 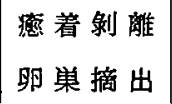 & $\begin{array}{l}\mathrm{Po}_{2} \\
\mathrm{PcO} 2 \\
\mathrm{pH}\end{array}$ & $\begin{array}{r}86 \\
34 \\
7.34\end{array}$ & $\begin{array}{r}93 \\
38 \\
7.32\end{array}$ & $\begin{array}{r}88 \\
40 \\
7.30\end{array}$ & $\begin{array}{r}80 \\
42 \\
7.33\end{array}$ & $\begin{array}{r}82 \\
35 \\
7.32\end{array}$ & $\begin{array}{r}81 \\
33 \\
7.33\end{array}$ \\
\hline 41 & $=0$ & $\begin{array}{c}\delta \\
29\end{array}$ & 腸䱦着 & 試験 開 腹 & \begin{tabular}{|l}
$\mathrm{Po}_{2}$ \\
$\mathrm{PcO}_{2}$ \\
$\mathrm{pH}$
\end{tabular} & $\begin{array}{r}85 \\
36 \\
7.32\end{array}$ & $\begin{array}{r}70 \\
38 \\
7.32\end{array}$ & $\begin{array}{r}64 \\
40 \\
7.32\end{array}$ & $\begin{array}{r}76 \\
32 \\
7.38\end{array}$ & $\begin{array}{r}75 \\
38 \\
7.36\end{array}$ & $\begin{array}{r}82 \\
35 \\
7.37\end{array}$ \\
\hline 42 & 真O -0 & $\left|\begin{array}{c}\hat{o} \\
63\end{array}\right|$ & 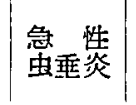 & 虫垂切除 & $\begin{array}{l}\mathrm{Po} 2 \\
\mathrm{PcO} 2 \\
\mathrm{pH}\end{array}$ & $\begin{array}{r}72 \\
37 \\
7.36\end{array}$ & $\begin{array}{r}67 \\
35 \\
7.34\end{array}$ & $\begin{array}{r}68 \\
37 \\
7.32\end{array}$ & $\begin{array}{r}77 \\
38 \\
7.35\end{array}$ & $\begin{array}{r}83 \\
36 \\
7.38\end{array}$ & $\begin{array}{r}82 \\
37 \\
7.37\end{array}$ \\
\hline 43 & 須O & $\left|\begin{array}{c}\uparrow \\
25\end{array}\right|$ & 急性 & 由垂切除 & $\begin{array}{l}\mathrm{Po}_{2} \\
\mathrm{PcO}_{2} \\
\mathrm{pH}\end{array}$ & $\begin{array}{r}75 \\
41 \\
7.32\end{array}$ & $\begin{array}{r}80 \\
42 \\
7.30\end{array}$ & $\begin{array}{r}82 \\
47 \\
7.28\end{array}$ & $\begin{array}{r}78 \\
38 \\
7.38\end{array}$ & $\begin{array}{r}82 \\
40 \\
7.38\end{array}$ & $\begin{array}{r}80 \\
36 \\
7.36 \\
\end{array}$ \\
\hline 44 & 福O & $\begin{array}{c}5 \\
30\end{array}$ & $\begin{array}{l}\text { 急珄 } \\
\text { 虫垂炎 }\end{array}$ & 中垂切除 & $\begin{array}{l}\mathrm{PO}_{2} \\
\mathrm{PcO}_{2} \\
\mathrm{pH}\end{array}$ & $\begin{array}{r}82 \\
36 \\
7.37\end{array}$ & $\begin{array}{r}84 \\
40 \\
7.38\end{array}$ & $\begin{array}{r}80 \\
38 \\
7.39 \\
\end{array}$ & $\begin{array}{r}78 \\
36 \\
7.37\end{array}$ & $\begin{array}{r}82 \\
37 \\
7.37\end{array}$ & $\begin{array}{r}78 \\
36 \\
7.36\end{array}$ \\
\hline 45 & 山O & $\begin{array}{l}\text { 우 } \\
20\end{array}$ & 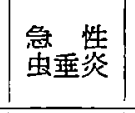 & 由垂切除 & $\begin{array}{l}\mathrm{Po}_{2} \\
\mathrm{PcO} 2 \\
\mathrm{pH}\end{array}$ & $\begin{array}{r}90 \\
36 \\
7.36\end{array}$ & $\begin{array}{r}88 \\
38 \\
7.34 \\
\end{array}$ & $\begin{array}{r}82 \\
40 \\
7.34 \\
\end{array}$ & $\begin{array}{r}84 \\
34 \\
7.36 \\
\end{array}$ & $\begin{array}{r}84 \\
43 \\
7.38 \\
\end{array}$ & $\begin{array}{r}95 \\
35 \\
7.36 \\
\end{array}$ \\
\hline 46 & 古O 史O & $\begin{array}{l}\delta \\
41\end{array}$ & 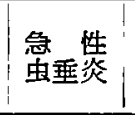 & 虫垂切除 & $\begin{array}{l}\mathrm{Po}_{2} \\
\mathrm{PcO}_{2} \\
\mathrm{pH}\end{array}$ & $\begin{array}{r}85 \\
38 \\
7.36 \\
\end{array}$ & $\begin{array}{r}67 \\
38 \\
7.41 \\
\end{array}$ & $\begin{array}{r}72 \\
35 \\
7.40 \\
\end{array}$ & $\begin{array}{r}78 \\
49 \\
7.39 \\
\end{array}$ & $\begin{array}{r}80 \\
35 \\
7.39 \\
\end{array}$ & $\begin{array}{r}90 \\
34 \\
7.40\end{array}$ \\
\hline 47 & 本 $\bigcirc$ 静 $\mathrm{O}$ & $\begin{array}{c}\text { 우 } \\
40\end{array}$ & $\begin{array}{l}\text { 急性 } \\
\text { 虫垂 }\end{array}$ & 虫垂切除 & $\begin{array}{l}\mathrm{Po}_{2} \\
\mathrm{PcO}_{2} \\
\mathrm{pH}\end{array}$ & $\begin{array}{r}82 \\
34 \\
7.39 \\
\end{array}$ & $\begin{array}{r}70 \\
38 \\
7.41\end{array}$ & $\begin{array}{r}82 \\
40 \\
7.41\end{array}$ & $\begin{array}{r}85 \\
36 \\
7.39\end{array}$ & $\begin{array}{r}90 \\
34 \\
7.37\end{array}$ & $\begin{array}{r}89 \\
37 \\
7.37\end{array}$ \\
\hline 48 & 戸○ 良O & $\begin{array}{c}\hat{\delta} \\
29\end{array}$ & $\begin{array}{l}\text { 急笔 } \\
\text { 虫垂 }\end{array}$ & 虫垂切除 & $\begin{array}{l}\mathrm{PO}_{2} \\
\mathrm{PcO}_{2} \\
\mathrm{pH}\end{array}$ & $\begin{array}{r}90 \\
38 \\
7.42 \\
\end{array}$ & $\begin{array}{r}88 \\
34 \\
7.40 \\
\end{array}$ & $\begin{array}{r}83 \\
35 \\
7.38 \\
\end{array}$ & $\begin{array}{r}85 \\
40 \\
7.36 \\
\end{array}$ & $\begin{array}{r}90 \\
36 \\
7.37 \\
\end{array}$ & $\begin{array}{r}95 \\
34 \\
7.39 \\
\end{array}$ \\
\hline 49 & 町重O & $\begin{array}{c}\text { 의 } \\
39\end{array}$ & 誉蛀 & 中垂切除 & $\begin{array}{l}\mathrm{PO}_{2} \\
\mathrm{PcO}_{2} \\
\mathrm{pH}\end{array}$ & $\begin{array}{r}93 \\
34 \\
7.37\end{array}$ & $\begin{array}{r}87 \\
33 \\
7.30 \\
\end{array}$ & $\begin{array}{r}80 \\
40 \\
7.31 \\
\end{array}$ & $\begin{array}{r}85 \\
40 \\
7.40 \\
\end{array}$ & $\begin{array}{r}79 \\
35 \\
7.38 \\
\end{array}$ & $\begin{array}{r}86 \\
33 \\
7.39 \\
\end{array}$ \\
\hline 50 & IO 末 & $\begin{array}{r}\hat{\delta} \\
49 \\
\end{array}$ & $\begin{array}{l}\text { 急性 } \\
\text { 虫垂炎 }\end{array}$ & 虫垂切除 & $\begin{array}{l}\mathrm{Po}_{2} \\
\mathrm{PcO}_{2} \\
\mathrm{pH}\end{array}$ & $\begin{array}{r}83 \\
40 \\
7.38 \\
\end{array}$ & $\begin{array}{r}70 \\
32 \\
7.40 \\
\end{array}$ & $\begin{array}{r}83 \\
30 \\
7.33 \\
\end{array}$ & $\begin{array}{r}86 \\
31 \\
7.32 \\
\end{array}$ & $\begin{array}{r}90 \\
38 \\
7.37 \\
\end{array}$ & $\begin{array}{r}90 \\
37 \\
7.39\end{array}$ \\
\hline 51 & 武O 嘉O & $\begin{array}{c}\hat{\delta} \\
29\end{array}$ & 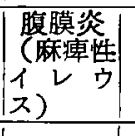 & 腸 & $\begin{array}{l}\mathrm{Po}_{2} \\
\mathrm{PcO} 2 \\
\text { pH }\end{array}$ & $\begin{array}{r}78 \\
40 \\
7.28\end{array}$ & $\begin{array}{r}76 \\
43 \\
7.27\end{array}$ & $\begin{array}{r}78 \\
45 \\
7.24\end{array}$ & 死 & & 亡 \\
\hline 52 & 藤O凶OO & $\begin{array}{r}9 \\
25\end{array}$ & 腸療着 & $\begin{array}{l}\text { 小腸・横行 } \\
\text { 結腸 勋合 } \\
\text { 腸 }\end{array}$ & $\begin{array}{l}\mathrm{Po}_{2} \\
\mathrm{PcO}_{2} \\
\mathrm{pH}\end{array}$ & $\begin{array}{r}85 \\
43 \\
7.36\end{array}$ & $\begin{array}{r}75 \\
42 \\
7.30\end{array}$ & $\begin{array}{r}65 \\
37 \\
7.36\end{array}$ & $\begin{array}{r}67 \\
33 \\
7.36\end{array}$ & $\begin{array}{r}72 \\
40 \\
7.38\end{array}$ & $\begin{array}{r}74 \\
36 \\
7.35 \\
\end{array}$ \\
\hline 53 & 鉿○藤OO & $\begin{array}{l}\hat{\sigma} \\
58\end{array}$ & 直腸癌 & 試験開腹 & $\begin{array}{l}\mathrm{Po}_{2} \\
\mathrm{PcO} 2 \\
\mathrm{pH}\end{array}$ & $\begin{array}{r}82 \\
38 \\
7.38\end{array}$ & $\begin{array}{r}80 \\
41 \\
7.40\end{array}$ & $\begin{array}{r}78 \\
36 \\
7.36\end{array}$ & $\begin{array}{r}80 \\
38 \\
7.34\end{array}$ & $\begin{array}{r}76 \\
40 \\
7.36\end{array}$ & $\begin{array}{r}84 \\
40 \\
7.38\end{array}$ \\
\hline 54 & 佐○○梅O & $\begin{array}{r}\text { 우 } \\
13\end{array}$ & 直腸臸痽 & $\underset{\text { 閉 }}{\text { 工鎖 }}$ 門 & $\begin{array}{l}\mathrm{PO}_{2} \\
\mathrm{PcO}_{2} \\
\mathrm{pH}\end{array}$ & $\begin{array}{r}78 \\
43 \\
7.37\end{array}$ & $\begin{array}{r}78 \\
40 \\
7.36 \\
\end{array}$ & $\begin{array}{r}73 \\
46 \\
7.35\end{array}$ & $\begin{array}{r}84 \\
34 \\
7.37\end{array}$ & $\begin{array}{r}86 \\
33 \\
7.37\end{array}$ & $\begin{array}{r}86 \\
35 \\
7.38\end{array}$ \\
\hline 55 & 落O & \begin{tabular}{l|l|} 
\\
20
\end{tabular} & 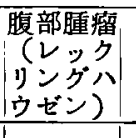 & 試跧開腹 & $\begin{array}{l}\mathrm{Po}_{2} \\
\mathrm{PcO}_{2} \\
\mathrm{pH}\end{array}$ & $\begin{array}{r}83 \\
50 \\
7.30\end{array}$ & $\begin{array}{r}70 \\
42 \\
7.38\end{array}$ & $\begin{array}{r}60 \\
40 \\
7.41\end{array}$ & $\begin{array}{r}64 \\
41 \\
7.40\end{array}$ & $\begin{array}{r}82 \\
38 \\
7.38\end{array}$ & $\begin{array}{r}82 \\
36 \\
7.38\end{array}$ \\
\hline 56 & MO英OO & $\begin{array}{l}3 \\
64 \\
\end{array}$ & 膵甈癌 & 試験 開腹 & $\begin{array}{l}\mathrm{PO}_{2} \\
\mathrm{PcO}_{2} \\
\mathrm{pH}\end{array}$ & $\begin{array}{r}84 \\
38 \\
7.40\end{array}$ & $\begin{array}{r}76 \\
40 \\
7.41\end{array}$ & $\begin{array}{r}72 \\
41 \\
7.40\end{array}$ & $\begin{array}{r}78 \\
36 \\
7.40\end{array}$ & $\begin{array}{r}80 \\
37 \\
7.36 \\
\end{array}$ & $\begin{array}{r}84 \\
36 \\
7.38 \\
\end{array}$ \\
\hline 57 & 落O & \begin{tabular}{c|}
$\hat{\delta}$ \\
20
\end{tabular} & 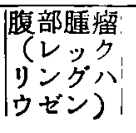 & $\underset{\text { 造 }}{人}$ 工肛 閔 & $\begin{array}{l}\mathrm{PO}_{2} \\
\mathrm{PcO}_{2} \\
\mathrm{pH}\end{array}$ & $\begin{array}{r}83 \\
38 \\
7.40\end{array}$ & $\begin{array}{r}82 \\
44 \\
7.39\end{array}$ & $\begin{array}{r}78 \\
42 \\
7.38\end{array}$ & $\begin{array}{r}84 \\
36 \\
7.39\end{array}$ & $\begin{array}{r}78 \\
40 \\
7.38\end{array}$ & $\begin{array}{r}80 \\
40 \\
7.37\end{array}$ \\
\hline
\end{tabular}




\begin{tabular}{|c|c|c|c|c|c|c|c|c|c|c|c|c|}
\hline 58 & 桑 $\bigcirc$ & 啨O & $\begin{array}{r}9 \\
43\end{array}$ & 子宮筋㬽 & 子宮切断 & $\begin{array}{l}\mathrm{Po}_{2} \\
\mathrm{PcO}_{2} \\
\mathrm{pH}\end{array}$ & $\begin{array}{r}83 \\
37 \\
7.40 \\
\end{array}$ & $\begin{array}{r}75 \\
52 \\
7.36 \\
\end{array}$ & $\begin{array}{r}76 \\
43 \\
7.44 \\
\end{array}$ & $\begin{array}{r}82 \\
37 \\
7.38 \\
\end{array}$ & $\begin{array}{r}83 \\
37 \\
7.37 \\
\end{array}$ & $\begin{array}{r}84 \\
36 \\
7.37\end{array}$ \\
\hline 59 & 大O & 宙O & $\begin{array}{c}\delta \\
70\end{array}$ & 鼠 & 根治手術 & $\begin{array}{l}\mathrm{Po}_{3} \\
\mathrm{PcO}_{2} \\
\mathrm{pH}\end{array}$ & $\begin{array}{r}80 \\
32 \\
7.43\end{array}$ & $\begin{array}{r}74 \\
30 \\
7.40\end{array}$ & $\begin{array}{r}73 \\
37 \\
7.35\end{array}$ & $\begin{array}{r}76 \\
35 \\
3.42\end{array}$ & $\begin{array}{r}73 \\
37 \\
7.40\end{array}$ & $\begin{array}{rr}: & 71 \\
1 & 36 \\
: \quad 7.41\end{array}$ \\
\hline 60 & 岩O & $た O$ & $\begin{array}{l}\text { 우 } \\
59\end{array}$ & $\mid$ 腹 & 梖治手術 & $\begin{array}{l}\mathrm{Po}_{2} \\
\mathrm{Pco}_{2} \\
\mathrm{pH}\end{array}$ & $\begin{array}{r}85 \\
34 \\
7.33\end{array}$ & $\begin{array}{r}80 \\
38 \\
7.31\end{array}$ & $\begin{array}{r}72 \\
40 \\
7.37\end{array}$ & $\begin{array}{r}82 \\
45 \\
7.38\end{array}$ & $\begin{array}{r}75 \\
37 \\
7.37\end{array}$ & $\begin{array}{r}78 \\
36 \\
7.41\end{array}$ \\
\hline 61 & 山O & 昌O & $\begin{array}{l}\hat{\delta} \\
21\end{array}$ & $\begin{array}{l}\text { 鼠径リン } \\
\text { パ脉腫脹 }\end{array}$ & 試験切除 & $\begin{array}{l}\mathrm{Po}_{2} \\
\mathrm{Pco}_{2} \\
\mathrm{pH}\end{array}$ & $\begin{array}{r}83 \\
34 \\
7.37\end{array}$ & $\begin{array}{r}81 \\
37 \\
7.36\end{array}$ & $\begin{array}{r}75 \\
38 \\
7.37\end{array}$ & $\begin{array}{r}80 \\
40 \\
7.36\end{array}$ & $\begin{array}{r}73 \\
34 \\
7.34\end{array}$ & $\begin{array}{r}86 \\
32 \\
7.36\end{array}$ \\
\hline 62 & 沼O & 竹O & $\begin{array}{c}\hat{\sigma} \\
19\end{array}$ & 庤 核 & 根治手 衡 & $\begin{array}{l}\mathrm{Po}_{2} \\
\mathrm{PcO}_{2} \\
\mathrm{pH}\end{array}$ & $\begin{array}{r}89 \\
38 \\
7 \cdot 37\end{array}$ & $\begin{array}{r}82 \\
35 \\
7.35\end{array}$ & $\begin{array}{r}96 \\
45 \\
7.36\end{array}$ & $\begin{array}{r}86 \\
42 \\
7.39\end{array}$ & $\begin{array}{r}83 \\
38 \\
7.38\end{array}$ & $\begin{array}{r}84 \\
36 \\
7.36\end{array}$ \\
\hline 63 & 林 & ま○ & \begin{tabular}{r|} 
우 \\
28
\end{tabular} & 甲状腺腫 & 摘 & $\begin{array}{l}\mathrm{Po}_{2} \\
\mathrm{PcO}_{2} \\
\mathrm{pH}\end{array}$ & $\begin{array}{r}82 \\
42 \\
7.43\end{array}$ & $\begin{array}{r}90 \\
35 \\
7.39\end{array}$ & $\begin{array}{r}83 \\
45 \\
7.41\end{array}$ & $\begin{array}{r}80 \\
38 \\
7.39\end{array}$ & $\begin{array}{r}82 \\
35 \\
7.37\end{array}$ & $\begin{array}{r}83 \\
26 \\
7.37\end{array}$ \\
\hline 64 & 東○美 & 500 & $\begin{array}{c}\text { 우 } \\
37\end{array}$ & 甲状腺萿 & 㩲 & $\begin{array}{l}\mathrm{Po}_{2} \\
\mathrm{PcO}_{2} \\
\mathrm{pH}\end{array}$ & $\begin{array}{r}80 \\
42 \\
7.38\end{array}$ & $\begin{array}{r}66 \\
43 \\
7.36\end{array}$ & $\begin{array}{r}77 \\
43 \\
7.41\end{array}$ & $\begin{array}{r}78 \\
40 \\
7.38\end{array}$ & $\begin{array}{r}75 \\
37 \\
7.35\end{array}$ & $\begin{array}{r}78 \\
36 \\
7.34\end{array}$ \\
\hline 65 & 安○ & 悲 & $\begin{array}{c}\widehat{\sigma} \\
38\end{array}$ & 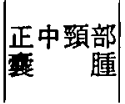 & 摘 & $\begin{array}{l}\mathrm{Po}_{2} \\
\mathrm{PcO}_{2} \\
\mathrm{pH}\end{array}$ & $\begin{array}{r}93 \\
40 \\
7.36\end{array}$ & $\begin{array}{r}85 \\
36 \\
7.39\end{array}$ & $\begin{array}{r}82 \\
34 \\
7.36\end{array}$ & $\begin{array}{r}84 \\
38 \\
7.38\end{array}$ & $\begin{array}{r}80 \\
36 \\
7.40\end{array}$ & $\begin{array}{r}82 \\
35 \\
7.36\end{array}$ \\
\hline 66 & 矢 0 & 良O & $\begin{array}{c}\text { 우 } \\
23\end{array}$ & 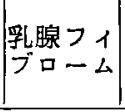 & 摘 & $\begin{array}{l}\mathrm{Po}_{2} \\
\mathrm{PcO}_{2} \\
\mathrm{pH}\end{array}$ & $\begin{array}{r}92 \\
36 \\
7.37 \\
\end{array}$ & $\begin{array}{r}82 \\
40 \\
7.38 \\
\end{array}$ & $\begin{array}{r}86 \\
38 \\
7.36\end{array}$ & $\begin{array}{r}82 \\
39 \\
7.36\end{array}$ & $\begin{array}{r}84 \\
40 \\
7.39\end{array}$ & $\begin{array}{r}86 \\
41 \\
7.35\end{array}$ \\
\hline 67 & 福O & 鴨O & $\begin{array}{c}\widehat{\delta} \\
42\end{array}$ & $\begin{array}{l}\text { 贀部アテ } \\
\text { ローム }\end{array}$ & 摘 & $\begin{array}{l}\mathrm{Po}_{2} \\
\mathrm{PcO}_{2} \\
\mathrm{pH}\end{array}$ & $\begin{array}{r}36 \\
88 \\
7.40\end{array}$ & $\begin{array}{r}90 \\
42 \\
7.43\end{array}$ & $\begin{array}{r}84 \\
41 \\
7.42\end{array}$ & $\begin{array}{r}80 \\
36 \\
7.41\end{array}$ & $\begin{array}{r}87 \\
33 \\
7.40\end{array}$ & $\begin{array}{r}89 \\
39 \\
7.49\end{array}$ \\
\hline 68 & 遠O & 英O & $\begin{array}{c}\hat{\delta} \\
26\end{array}$ & $\begin{array}{l}\text { 胃はん } \\
\text { 寸う症 }\end{array}$ & 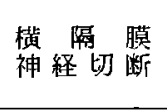 & $\begin{array}{l}\mathrm{Po}_{2} \\
\mathrm{PcO}_{2} \\
\mathrm{pH}\end{array}$ & $\begin{array}{r}83 \\
45 \\
7.40\end{array}$ & $\begin{array}{r}100 \\
38 \\
7.35\end{array}$ & $\begin{array}{r}82 \\
50 \\
7.39\end{array}$ & $\begin{array}{r}80 \\
43 \\
7.38\end{array}$ & $\begin{array}{r}82 \\
40 \\
7.36\end{array}$ & $\begin{array}{r}84 \\
42 \\
7.36\end{array}$ \\
\hline 69 & EIO & 信O & \begin{tabular}{c|} 
今 \\
49
\end{tabular} & $\begin{array}{l}\text { 特発性 } \\
\text { 眖 瘨 }\end{array}$ & 交感神経 & $\begin{array}{l}\mathrm{Po}_{2} \\
\mathrm{PcO}_{2} \\
\mathrm{pH}\end{array}$ & $\begin{array}{r}86 \\
36 \\
7.40 \\
\end{array}$ & $\begin{array}{r}78 \\
35 \\
7.42 \\
\end{array}$ & $\begin{array}{r}82 \\
34 \\
7.40 \\
\end{array}$ & $\begin{array}{r}86 \\
38 \\
7.41 \\
\end{array}$ & $\begin{array}{r}84 \\
36 \\
7.38 \\
\end{array}$ & $\begin{array}{r}87 \\
38 \\
7.39 \\
\end{array}$ \\
\hline 70 & 空O & 順O & $\begin{array}{c}\text { 우 } \\
40 \\
\end{array}$ & 熱伤瘦痕 & 形 成 衡 & $\begin{array}{l}\mathrm{Po}_{2} \\
\mathrm{PcO}_{2} \\
\mathrm{pH}\end{array}$ & $\begin{array}{r}85 \\
45 \\
7.37\end{array}$ & $\begin{array}{r}80 \\
42 \\
7.38 \\
\end{array}$ & $\begin{array}{r}76 \\
40 \\
7.39 \\
\end{array}$ & $\begin{array}{r}78 \\
40 \\
7.40\end{array}$ & $\begin{array}{r}83 \\
45 \\
7.40\end{array}$ & $\begin{array}{r}92 \\
42 \\
7.37 \\
\end{array}$ \\
\hline 71 & i中 & 00 & $\begin{array}{c}\text { 우 } \\
10\end{array}$ & 睬腫愫 & 開 頭 徱 & $\begin{array}{l}\mathrm{Po}_{2} \\
\mathrm{PcO}_{2} \\
\mathrm{pH}\end{array}$ & $\begin{array}{r}97 \\
33 \\
7.38\end{array}$ & $\begin{array}{r}72 \\
38 \\
7.30\end{array}$ & $\begin{array}{r}64 \\
42 \\
7.35\end{array}$ & $\begin{array}{r}103 \\
35 \\
7.40\end{array}$ & $\begin{array}{r}90 \\
34 \\
7.39\end{array}$ & $\begin{array}{r}89 \\
37 \\
7.38\end{array}$ \\
\hline
\end{tabular}

前後に動脈血の $\mathrm{Po}_{2}, \mathrm{Pco}_{2}$ および $\mathrm{pH}$ を測定し（表

4）その変動を追求すると図 8 の如く各手術部位と ち略同一の傾向を示した。

\section{$\mathbf{P o}_{2}$}

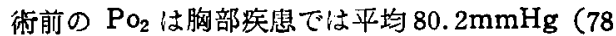
$\sim 86 \mathrm{mmHg})$ ，上腹部疾㭧 $83.6 \mathrm{mmHg}(70 \sim 100 \mathrm{~m}$ $\mathrm{mHg})$, 下腹部疾患 $83.1 \mathrm{mmHg}(72 \sim 100 \mathrm{mmHg})$, 四肢その他の疾患では86.6 mmHg (80〜97mmHg) であり，各部位とるほぼ正常值を示していた。
街後当日, 胸部手衒で注平均 $70.8 \mathrm{mmHg}(68 \sim 73$ $\mathrm{mmHg}$ )であり, 上腹部手術では $78.8 \mathrm{mmHg}$ (65 $\sim 104 \mathrm{mmHg})$, 下腹部手術 $77.3 \mathrm{mmHg}(60 \sim 93 \mathrm{~m}$ $\mathrm{mHg}$ )，四肢その他の手術では $80.6 \mathrm{mmHg}(66 \sim 90$ $\mathrm{mmHg})$ にそれぞれ減少し，胸部手菜では減少が著 しかった。

術後 I 日, 胸部手術では平均 $69.6 \mathrm{mmHg}(65 \sim 76$ $\mathrm{mmHg}$ ) であり, 上腹部手術の平均注 $71.6 \mathrm{mmHg}$ (59 85mmHg), 下腹部手郝 $75.4 \mathrm{mmHg}(60 \sim$ 
$83 \mathrm{mmHg}$ ), 四肢その他の手術では80.5 mmHg（64 〜96mmHg）で胸部手術ではその影響が最も大き く，四肢手術では柽度であった。

術後 3 日から饭復に向い，術後 7 日では胸部手術 では平均 $75.3 \mathrm{mmHg}(72 \sim 82 \mathrm{mmHg})$, 上腹部手術 では平均 $78.8 \mathrm{mmHg}(70 \sim 92 \mathrm{mmHg})$, 下腹部手術 では83. $4 \mathrm{mmHg}(70 \sim 95 \mathrm{mmHg})$, 四胡その他の手 街では85.6 $\mathrm{mmHg}(78 \sim 92 \mathrm{mmHg})$ て。胸部手街 上腹部手術ではまだ術前值に饭復していないか，四 肢手術ではほぼ術前值て欧復している。

\section{$\mathrm{Pco}_{2}$}

行前の $\mathrm{Pco}_{2}$ は胸部突患では平均 $37.2 \mathrm{mmHg}$ (33 $\sim 40 \mathrm{mmHg}$ ), 上腹部疾患では平均 $39.0 \mathrm{mmHg}$ (32 $\sim 45 \mathrm{mmHg}$ ), 下腹部疾思では平均 $37.8 \mathrm{mmHg}$ (30 $\sim 50 \mathrm{mmHg}$ )，四肢亏の他の疾患では平均 $38.4 \mathrm{~mm}$ $\mathrm{Hg}$ (33〜 42mmHg) で各疾患部位の問に著明な差 は認められない。

胸部手術では術後 I 日に，この他の手術部位では 術当日に $\mathrm{Pco}_{2}$ の增加がみられたが，著明な変動は なく術後7日にはすへて略術前值に恢復している。 pH

術前の $\mathrm{pH}$ は胸部疾患では平均 7.37 ( 7.34

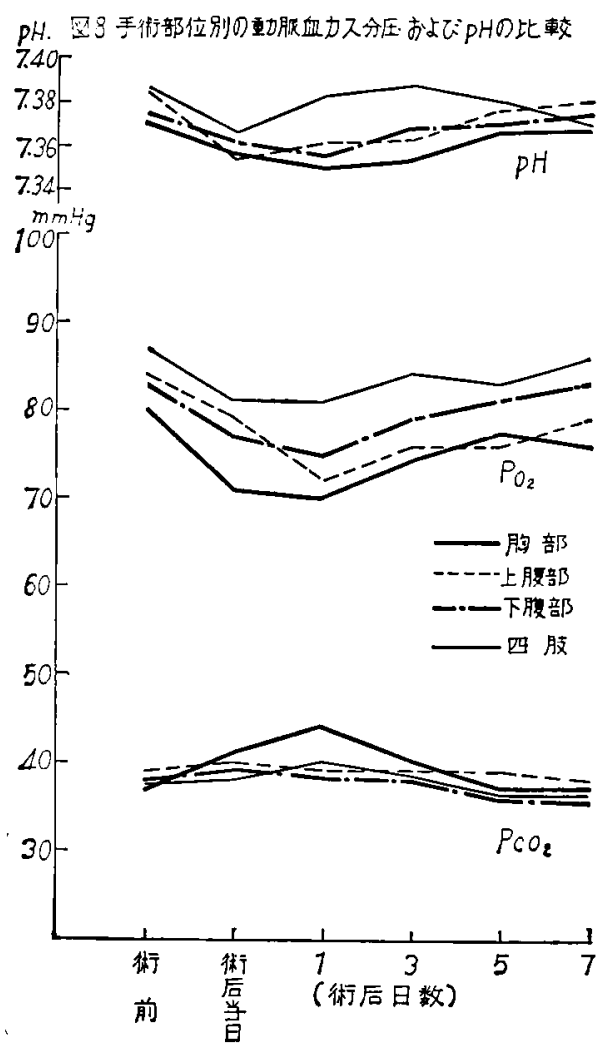

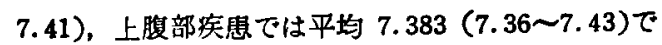
あり, 下腹部疾思では平均 $7.372(7.30 \sim 7.43)$ で あり, 四肢その他の疾患では 平均 7.384（7.36〜 7.43）と各部位とも近似の值を示していた。

術後当日, 胸部手術では平均7.358(7.34 7.40), 上腹部手術では平均 $7.356(7.30 \sim 7.41)$, 下腹部 手術では平均 $7.362(7.30 \sim 7.41)$, 四肢その他の 手術では平均 7.367 (7.30 7.43) で，各手術部位 ともアチドージスの傾向を示したが，街後 3 日，術 後 5 日には術前值に近ずき，術後 7 日には各手術部 位とも術前值範囲内に恢復している。

3. 小 括

外科的諸疾患71例の手術前後における動脈血 $\mathrm{Po}_{2}$ $\mathrm{Pco}_{2}$ および $\mathrm{pH}$ を测定した成績を一覧すると，手 術前後における $\mathrm{Po}_{2}, \mathrm{Pco}_{2}$ および $\mathrm{pH}$ の変動は各 手術部位ともはば同一傾向を示している。（図 8） 即ち, Po2では術後当日から減少し, 術後 1 日には 最低值を示しており, その程度は胸部手術が最も著 しく，上腹部手術がてれにつぎ，下腹部手術，四肢 手術では軽度である。術後 3 日から坂復に向い，術 後 7 日では下腹部手術, 四肢手術では術前値に恢復 しているが，胸部手術ではなお術前值に收復してい

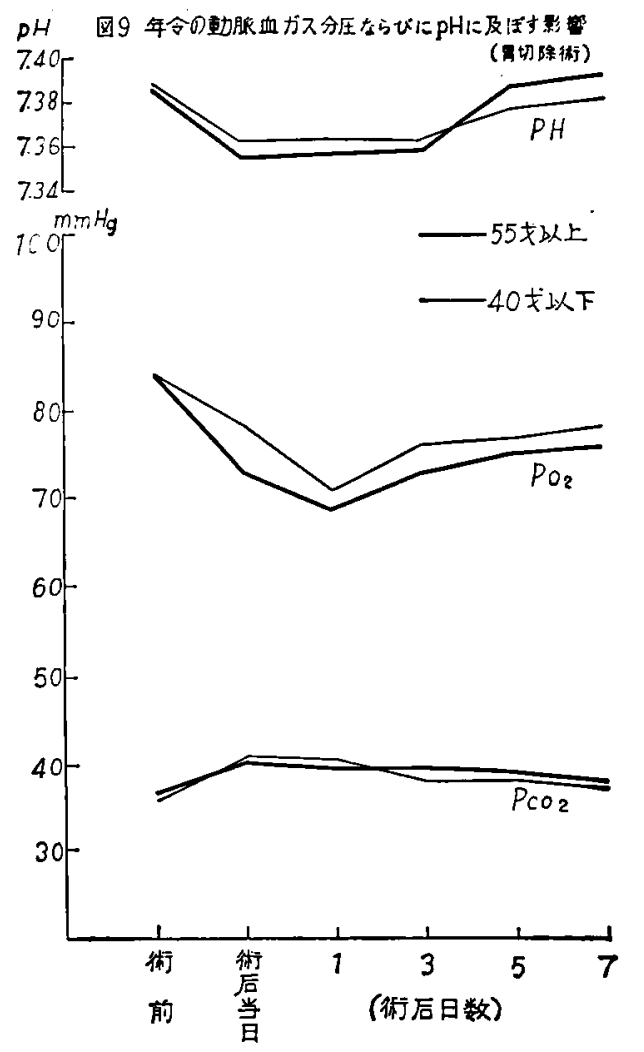


ない。 $\mathrm{PcO}_{2}$ は術後当日または涌後 1 日に胸部手術 では增加するが，その他の手術部位の間には有意の 差はなく，術後 3 日から衔後 5 日にはいずれも術前 值に恢復している。

pH す街後当日ないし術後1 日に最も低下してれ は胸部手術が最も著しいが, 術後 3 日, 術後 5 日に は術前值筑国偟饭復する。

年令による動眽血ガス分圧ならびに $\mathrm{pH}$ およばす 影辢をみるため同一疾患(胃部分切除得)を行なった 15例について55才以上の老年者 6 例と，40才以下の

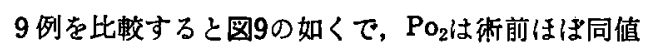
であるが，55才以上の群では術後当日，術後 1 日に 著明に減少し, 街後 3 日頃より欧復に向うが, 術後 7 日でる術前値以欧復していない。一方40才以下の 群も，老年者群とはば同椂の経過をとるが，その程 度は老年者群に比してやや軽度である。

$\mathrm{Pco}_{2}$ は耐群ともはほ同一の変動を示し, 術後一 過性に增加するが，両者の間には差は認められな い。 $\mathrm{pH}$ は術後当日または術後 1 日に低下を示す が, 術後 5 日に屾耐者とも術前值に復する。

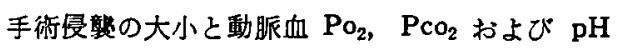
の変動との関保をみるため, 胃・十二指腸澮㻛に対

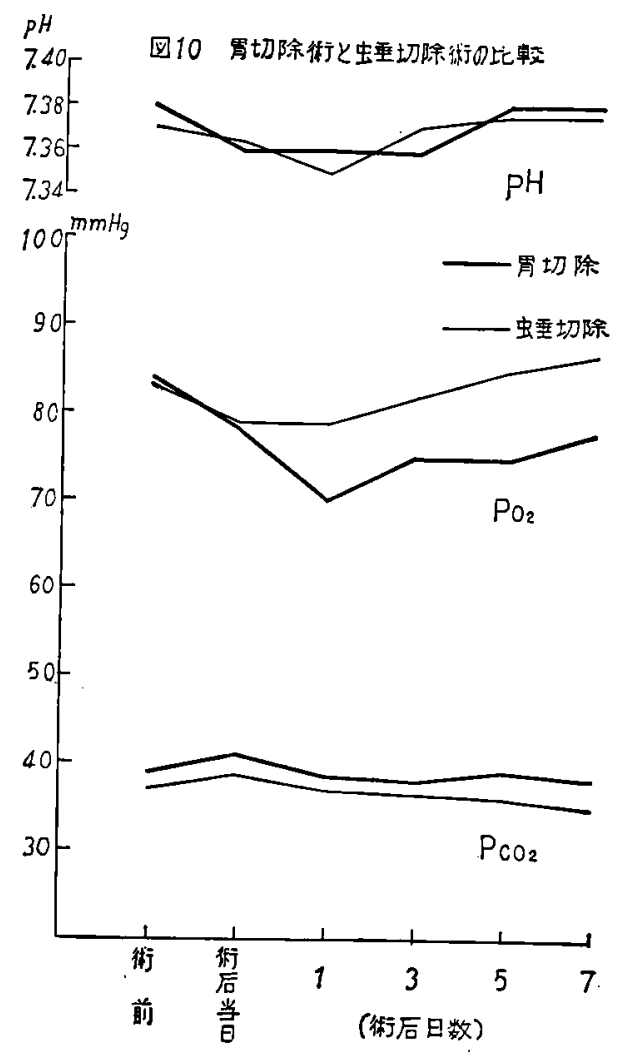

する胃切除郝13例と，単純件虫正炎に対する虫垂切 除 9 術例を比較すると，図10の如く，Po2 は街前雨 者とも略同值で，胃切除源では街後 1 日に著しく低 下し, 術後 3 日, 衍後 5 日には饭復に向うが胃切除 術は術後 7 日にわいても術前値に復していない。 $\mathrm{PcO}_{2}$ は原後当日は両者ともに一過性に，わずかに

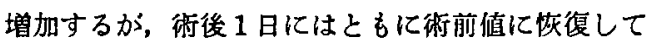
いる。 $\mathrm{pH}$ は衍前はともに略同值を示しているが， 術後当日には低下の傾向を示し, 術後 3 日より恢復 に向い, 術後 5 日には略術前範㽢に復している。

すなわち，年令の泟脈血 $\mathrm{Po}_{2}, \mathrm{Pco}_{2}, \mathrm{pH}$ におよ ぼす影䅉は, 図 9 の如く老年者㬝にやや強く現れて おり, 手術部位の動脈血 $\mathrm{Po}_{2}, \mathrm{Pco}_{2}, \mathrm{pH}$ におよは す影䪪は，胸部手衡に最も著明で，上腹部手衔がて れにつぎ，下腹部手很，四肢手衙では軽度であり。 その恢復も早い。これは, 各手䍀部位の比較に際し （胸部手街は若年者 1 例のため除外）55才以上のい わゆる䐈機能に年令が影薌を及ばすと考えられる年 令層を除外して比較してる同様の順位をなりま た, 上瑻部手郝中の胃切除術と, 下腹部手術中の单 純性虫垂切除街を比較しても, 両者の差は年令差以 上に大きいことからも推测される。

III 実験的気管支閉塞時の動脈血ガス分 圧および pH の変動（犬）

從来, 気管支開塞に上る実験的無気湖に関する研 究では，いずれる無気胡時には動脈血酸素飽和度は 減少するこいわれている。

著者が前記臨床例を篗察中に経験した衔後無気肺 例では（表 4 症例 15.28.64）その動脈血ガス分圧 に，他の術後経過例に比較して著明な变動を認めな い症例のあったことから，てれを明確にするため， 犬を用いて開胸的，また法，非開胸的に気管支を開 塞し, 閉塞前および閉塞後の動脈血ガス分圧, $\mathrm{pH}$ の変動を追求するとともに, 経時的に胸部 X線撮影 を行なって無気肺発生状況を観察した。

\section{1. 実臨材料亡方法}

健康な雑種成犬を用いて $(10 \sim 18 \mathrm{Kg})$, 実験当日 は絶食ののち, 塩酸モルヒネ $0.8 \mathrm{mg} / \mathrm{kg}$ を筋注し 注射の効果の現れたのを待って仰卧位に固定, 股動 眽より動眽血を採血测定し(第 3 章と同様の方法) その值の安定したときから実匼を開绐した。

\section{実験 1 :}

犬にネブタール静注下に気管内㨉管し，空気によ る補助呼吸を行ないながら右開胸, 右中葉気管支を 結紮閉塞したのち直ちに閉胸し, 開胸側胸腔内心陰 
左にもとし，胸部 X線写真により肺の再膨脤を確認 したのち, 麻酔から覚醒するのをまって動脈血 $\mathrm{Po}_{2}$, $\mathrm{PCO}_{2}, \mathrm{pH}$ の測定を行なった。以後遂日的に政脈血 ガス分圧わよび $\mathrm{pH}$ の測定と胸部 X線撮影を行なっ て無気腩発生状況を観察した。

実験 2 :

開胸による手術侵势が動脈血ガス分圧わよび $\mathrm{pH}$ におよばす影響を除外するため，先端にカフのつい

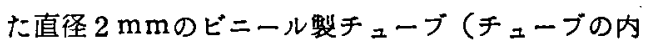
側に屈曲防止と伥満させたカフが気管支内から押し 出されるのを防ぐ目的で細い鋼針を通してある)を 創穿し、これをあらかしめ犬の気管内に挿管してあ ろ晽醉用気管チューブの中を通して犬の気管支内に 挿入し先端のカフを造影郕（80\%アンギオゴレイ約 4 CC）で充满し気管支の閉塞を行なった。気管支の 閉塞仕右気管支中部閉塞と右気管支未梢部閉塞の各 場合について, これぞれ閉塞後経時的に動眽血 $\mathrm{Po}_{2}$ $\mathrm{PCO}_{2}, \mathrm{pH}$ の測定を行ない，同時に胸部 X線撮影を 行なって無気肺発生状況さ観察した。

実験 3 :

闒塞より無気肺発生までの時間を短縮させる目的 で犬の気管内に挿管し高岡式レスピレーターを用い

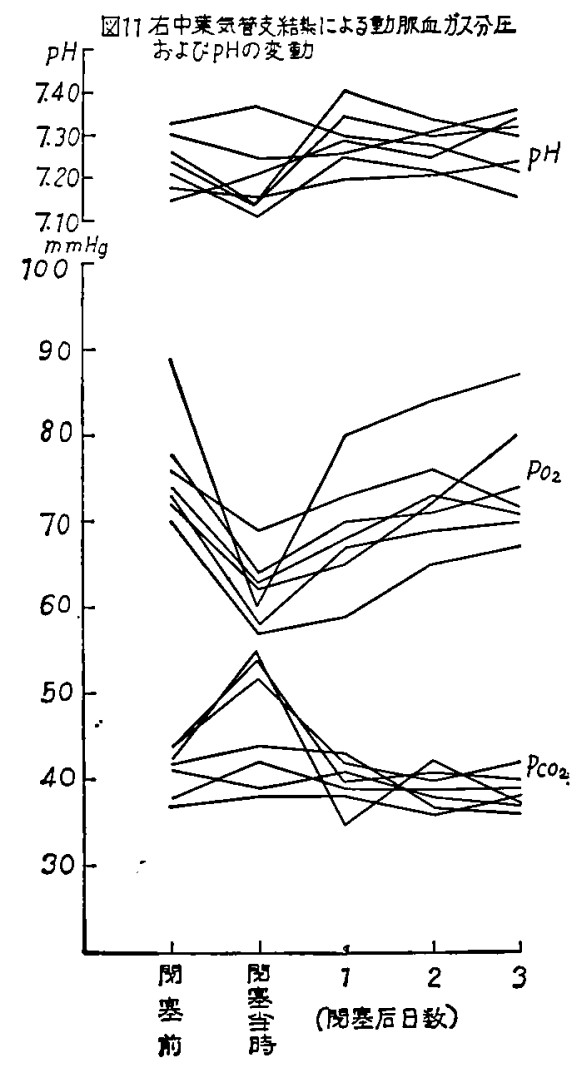

て $100 \%$ 酸素を15分間吸入させたのち, 前述のカフ つきチューブを用いて右気管支の中部または未梢部 を閉塞し，開塞後の $\mathrm{Po}_{2}, \mathrm{Pco}_{2}, \mathrm{pH}$ を経時的に測 定するとともに胸部 X線撮影を行なって無気肺発生 状況を観察した。実験に先立ち犬の股動静脈閭にシ リコンチューブによるシャントを形成し，その間に Beckman ガス分析器を挿入し, 動脈血 $\mathrm{Po}_{2}, \mathrm{Pco}_{2}$ の時々刻々の变化を読みとった。

\section{2. 成結}

実験 1 の成績

犬を閏胸し右中葉気管支を完全に結禁した。結热 前および結热後の $\mathrm{Po}, \mathrm{Pco}_{2}, \mathrm{pH}$ を経時的に測定 すると図11の如くで，Po2 は結禁前值平均 $79 \mathrm{mmHg}$ (72〜89mmHg) であり，結禁当日では $67 \mathrm{mmHg}$ (60〜69mmHg) と急激に低下する。一方 $\mathrm{Pco} 2$ は 結禁前值の平均は $42.5 \mathrm{mmHg}(42 \sim 43 \mathrm{mmHg})$ であったものが, 結禁後では $54 \mathrm{mmHg}(52 〜 55 \mathrm{~mm}$ $\mathrm{Hg}$ ）と著明に増加する。 $\mathrm{pH}$ は結禁前の平均 7.24 （7.18〜7.26）であるが, 結㷊後では7.15（7.14〜 7.16）と低下の傾向定示すが，結势後 1 日ではかえ って結禁前值をうわ迴る值7.31（7.20～7.40）を示 した。Po2 は結禁後2 日, $\mathrm{PCO}_{2}$ は結絷後 1 日では ぼ結焚剠值にまで恢復した。胸部 X線写真上気管

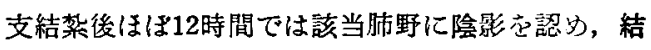
禁後 1 日で明らかに無気肺の像を認めるか⿱，胸腔内 䧔质の像は認められず結禁後 $48 \sim 72$ 時間の間に肺 虚脱の像が完成するがその時期では動脈血 $\mathrm{Po}$, $\mathrm{PCO}_{2}$ ねよび $\mathrm{pH}$ は恢復の㑯向を示している。

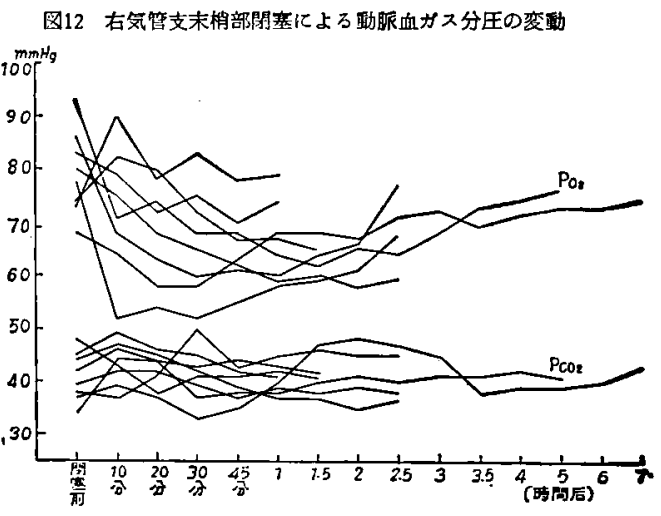

実験 2 の成績

右気管支末梢部を先端カフつきチューブを用いて 閉塞し, 閉塞前および閉塞後の動脈血 $\mathrm{Po}_{2}, \mathrm{Pco}_{2}$, $\mathrm{pH}$ を測定すると図12の如くである。

闒塞前の $\mathrm{Po} 2$ の平均は79.3mmHg（68〜93mm 

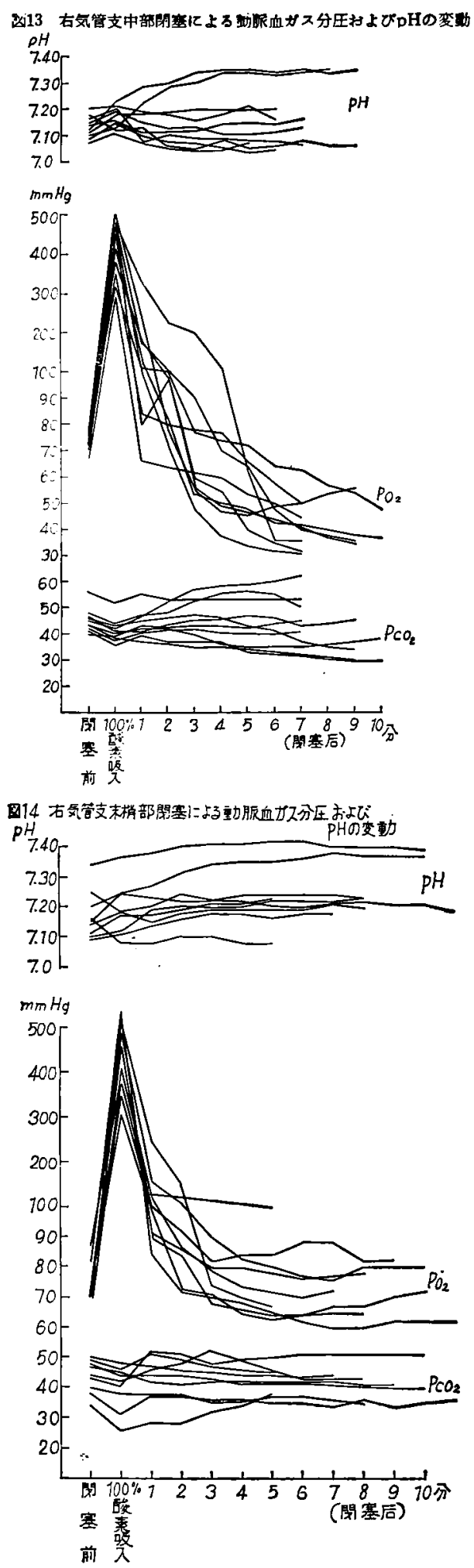

$\mathrm{Hg})$ であり, 閉塞後10分で:平均 $72.5 \mathrm{mmHg}$ (52 $\sim 90 \mathrm{mmHg}), 20$ 分では $68.2 \mathrm{mmHg}(54 \sim 80 \mathrm{~mm}$ $\mathrm{Hg}), 30$ 分では $66.7 \mathrm{mmHg}(52 \sim 83 \mathrm{mmHg}), 45$ 分では平均 $65.5 \mathrm{mmHg}(55 \sim 78 \mathrm{mmHg}) 60$ 分では $66.2 \mathrm{mmHg}(58 \sim 79 \mathrm{mmHg})$ と閉塞後 1 時閒頃よ り饭復のきざしがみられるが，閉塞後 2 時間半值の 平均は $68 \mathrm{mmHg}$ で, 閉塞前值に比して著明な低下 がみられる。一方閉塞前の $\mathrm{Pco}_{2}$ の平均は $40.5 \mathrm{~mm}$ $\mathrm{Hg}(34 \sim 47 \mathrm{mmHg})$ であり，閉塞後10分では 43.1 $\mathrm{mmHg}$ (36〜 48mmHg) と最高值を示し，20分後で は 42.1 $\mathrm{mmHg}(37 \sim 46 \mathrm{mmHg})$ と20分頃より比較 的安定した経過をとり閉基前值に恢復する。開塞後 7 時閒までの胸部 X線写真に:異常陰影の出現を認 めなかったが, 動脈血の $\mathrm{Po} 2, \mathrm{PcO}_{2}$ はは任闒塞前 の值に向って恢復する傾向がうかがわれる。

実験 3 の成續

$100 \%$ 酸素党 15 分間吸入後 $\mathrm{Po}_{2} \quad(300 \sim 500 \mathrm{~mm}$ $\mathrm{Hg}$ ）右気管支中部を閉塞すると（図13）, 閉塞直後 より Por は急激に娍少する。閉塞後10分までの経過 をみると Po2 は階段状任下し，最低值は Po2 30 $\mathrm{mmHg}$ 沂くを示すものもあった。一方 $\mathrm{Pco}_{2}$ は $100 \%$ 酸素10 間吸入により，全例に一過性の低下 を認めるが，以後わずかながら增加する傾向がうか がわれた。 $\mathrm{pH}$ は 2 例江增加する傾向を，残り 8 例 にはわずかずつではあるが低下する傾向を示しだ。 右気管支末梢部の開塞例でる（図14）Po2 は閉塞 後急激に低下し，閉塞後 5〜6 分までは䧊段状の低 下がられるが，以後は平行状態態を示す。Por 低 下の最低值は $60 \mathrm{mmHg}$ である。

一方 $\mathrm{Pco}_{2}$ は $100 \%$ 酸素吸入直後の一過性の减少 にひきつづき 1 分後は増加するが，以後わずかずつ 減少し, 閉塞後 5 分以後は全例はぼ不変值主示す。 $\mathrm{pH}$ は全例にわずかずつ上昇する傾向を示した。

胸部 X線写真では，気管支中部閉塞例，未梢開塞例 とるに，閉塞後 5 分には該当肺野(閉塞部以下胡野) に明らか子陰影の増强を，閉塞後10分では檤隔の患 側転位，横隔膜の挙上を明瞭に認めた。

3. 小 括

従来実験的無気肺大の作製には；手術的に気管支 を結檚する方法や，異物（ラミナリア桿，アラビア ゴム，綿球）を経気道的に挿入する方法等が試みら れているが，異物による気管支の閉塞方法では，10 0\% 酸素で肺内気体をほは完全に置換したのちに, 瞬時に気管支を完全に閉塞する操作には叙めて不適 当なため, 前述の如きカフによる閉塞方法を行なっ 
t。

犬の気管支を閉塞し, 閉塞前後の動脈血 $\mathrm{Po} 2, \mathrm{P}$ $\mathrm{Co}_{2}, \mathrm{pH}$ を測定すると, 閉塞直後 $\mathrm{Po}_{2}$ は著减し， $\mathrm{PCO}_{2}$ は増加する傾向を示した。即ち開塞後の動眽 血ガス分圧の変動は，開胸的に気管支を結槑しに犬 では（実験 1 ）手術の長量もあり，その変動す大き く饭復までに長時間を要するが，非用胸的にバルー ンにより閉塞しだ犬では（実験 2)，その閉塞部位 により, 閉塞が気管支未梢では饭復り速く，気管支 中部では恢復も遅征する。胸部 X線写真で，非開胸 的気管支開塞例では閉塞後 7 時間までは, 該当肺野 飞罢常陰影の出現は梕められなかったが，無気肺の 出現前, すでそ動脈血ガス分圧は饭復の傾向を示し

\section{ていた。}

$100 \%$ 酸素吸入直後，バルーンによる気管支閉等 犬では（実験 3 ）閉塞部が梢末気管支の場合には $\mathrm{Po}_{2}$ の低下， $\mathrm{Pco}_{2}$ の上昇の程度は軽く，その恢復 む速かであり，閉塞部が気管支中部の場合には $\mathrm{Po}_{2}$ 低下は急湤であり，敒復までの時間も遅延する。本 方法で胸部 X線写貞上, 該当肺野に異常陰影の出現 するまでの時間は 5 分以内であり，10分後には無気 肺側元の縦隔の転位, 横隔膜の上昇か認められた。 即ち，100\% 酸素吸入後，気管支閉塞を行なった急 速な無気肺作成時には， $\mathrm{X}$ 線写真上無気肺出現時に はなお，動脈血に著明な $\mathrm{Po}_{2}$ の低下が認められた。 IV 胸部圧迫腹部圧迫が肺換気譏能におよほす影

表 5 圧迫による肺換文機能の変動（健康人）

\begin{tabular}{|c|c|c|c|c|c|c|c|c|c|c|c|c|}
\hline 症例 & 氏 & & & 名 & 告命 & 圧迫 部 位 & 呼吸数 & $\frac{1}{\text { 回 }}$ & 分豀気量 & 吸気時間 & 呼気時間| & 肺 活 量 \\
\hline 1 & 荻 & 0 & 真 & $\mathrm{O}$ & $\begin{array}{c}\hat{\delta} \\
26\end{array}$ & 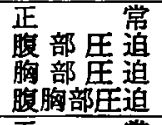 & $\begin{array}{l}10 \\
14 \\
13 \\
19 \\
\end{array}$ & $\begin{array}{l}900 \\
550 \\
600 \\
500 \\
\end{array}$ & $\begin{array}{l}9000 \\
7700 \\
7800 \\
9500 \\
\end{array}$ & $\begin{array}{l}3.0 \\
2.0 \\
2.0 \\
1.3 \\
\end{array}$ & $\begin{array}{l}2.8 \\
2.0 \\
2.1 \\
1.3 \\
\end{array}$ & $\begin{array}{l}4350 \\
3960 \\
3700 \\
3240 \\
\end{array}$ \\
\hline 2 & 佐 & 0 & 薏 & 0 & $\begin{array}{c}\hat{\delta} \\
25\end{array}$ & 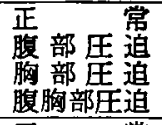 & $\begin{array}{l}20 \\
20 \\
21 \\
22 \\
\end{array}$ & $\begin{array}{l}700 \\
700 \\
700 \\
600 \\
\end{array}$ & $\begin{array}{l}14000 \\
14000 \\
14700 \\
13200 \\
\end{array}$ & $\begin{array}{l}1.3 \\
1.3 \\
1.2 \\
1.2 \\
\end{array}$ & $\begin{array}{l}1.6 \\
1.6 \\
1.6 \\
1.5 \\
\end{array}$ & $\begin{array}{l}4160 \\
3880 \\
3220 \\
2720 \\
\end{array}$ \\
\hline 3 & 西 & 0 & 豊 & $\mathrm{O}$ & $\begin{array}{c}\hat{\delta} \\
28\end{array}$ & 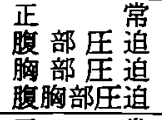 & $\begin{array}{l}14 \\
16 \\
16 \\
19 \\
\end{array}$ & $\begin{array}{l}600 \\
500 \\
400 \\
380 \\
\end{array}$ & $\begin{array}{l}8400 \\
8000 \\
6400 \\
7220 \\
\end{array}$ & $\begin{array}{l}1.8 \\
1.5 \\
1.4 \\
1.5 \\
\end{array}$ & $\begin{array}{l}2.4 \\
2.2 \\
2.3 \\
1.7 \\
\end{array}$ & $\begin{array}{l}3400 \\
3000 \\
2800 \\
2480 \\
\end{array}$ \\
\hline 4 & 岩 & 0 & 安 & 0 & $\begin{array}{c}\hat{\sigma} \\
27\end{array}$ & 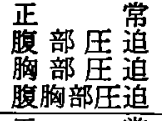 & $\begin{array}{l}13 \\
13 \\
15 \\
17 \\
\end{array}$ & $\begin{array}{l}500 \\
500 \\
400 \\
400 \\
\end{array}$ & $\begin{array}{l}6500 \\
6500 \\
6000 \\
6800 \\
\end{array}$ & $\begin{array}{l}2.0 \\
1.8 \\
1.5 \\
1.6 \\
\end{array}$ & $\begin{array}{l}2.6 \\
2.7 \\
2.5 \\
1.9 \\
\end{array}$ & $\begin{array}{l}3000 \\
2800 \\
2400 \\
2600 \\
\end{array}$ \\
\hline 5 & 坂 & 0 & 良 & 0 & $\begin{array}{c}\hat{\delta} \\
27\end{array}$ & $\begin{array}{l}\text { 正 } \\
\text { 腹 部王常 } \\
\text { 胸部 } \\
\text { 腹胸部庄迫 } \\
\end{array}$ & $\begin{array}{l}12 \\
12 \\
13 \\
14 \\
\end{array}$ & $\begin{array}{l}650 \\
600 \\
650 \\
580 \\
\end{array}$ & $\begin{array}{l}7800 \\
7200 \\
8450 \\
8120 \\
\end{array}$ & $\begin{array}{l}2.0 \\
1.8 \\
1.7 \\
1.7 \\
\end{array}$ & $\begin{array}{l}3.0 \\
3.1 \\
3.0 \\
2.5 \\
\end{array}$ & $\begin{array}{l}3450 \\
3200 \\
2900 \\
2600 \\
\end{array}$ \\
\hline 6 & 丸 & 0 & 恭 & 0 & $\begin{array}{c}\delta \\
28\end{array}$ & $\begin{array}{l}\text { 正 常 } \\
\text { 腹部压追 } \\
\text { 胸部压追 } \\
\text { 腹胸部压追 }\end{array}$ & $\begin{array}{l}13 \\
15 \\
14 \\
15 \\
\end{array}$ & $\begin{array}{l}580 \\
550 \\
550 \\
500 \\
\end{array}$ & $\begin{array}{l}7540 \\
8250 \\
7700 \\
7500 \\
\end{array}$ & $\begin{array}{l}2.0 \\
1.8 \\
1.8 \\
1.7 \\
\end{array}$ & $\begin{array}{l}2.7 \\
2.2 \\
2.5 \\
2.3 \\
\end{array}$ & $\begin{array}{l}4000 \\
3750 \\
3200 \\
3000 \\
\end{array}$ \\
\hline 7 & 及 & 0 & 征 & 0 & $\begin{array}{c}\hat{\delta} \\
27\end{array}$ & 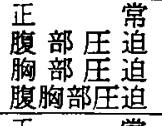 & $\begin{array}{l}14 \\
16 \\
18 \\
20 \\
\end{array}$ & $\begin{array}{l}500 \\
550 \\
500 \\
500 \\
\end{array}$ & $\begin{array}{r}7000 \\
8800 \\
9000 \\
10000 \\
\end{array}$ & $\begin{array}{l}1.5 \\
1.6 \\
1.4 \\
1.4 \\
\end{array}$ & $\begin{array}{l}2.2 \\
1.6 \\
1.6 \\
1.4 \\
\end{array}$ & $\begin{array}{l}4200 \\
4000 \\
3700 \\
3200 \\
\end{array}$ \\
\hline 8 & 村 & 0 & 正 & 0 & $\begin{array}{c}\hat{\delta} \\
34\end{array}$ & 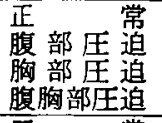 & $\begin{array}{l}12 \\
14 \\
14 \\
13 \\
\end{array}$ & $\begin{array}{r}1000 \\
750 \\
800 \\
600 \\
\end{array}$ & $\begin{array}{r}12000 \\
10500 \\
11200 \\
7800 \\
\end{array}$ & $\begin{array}{l}1.8 \\
1.5 \\
1.8 \\
1.5 \\
\end{array}$ & $\begin{array}{l}2.1 \\
2.0 \\
2.0 \\
2.0 \\
\end{array}$ & $\begin{array}{l}3600 \\
3000 \\
3100 \\
2900 \\
\end{array}$ \\
\hline 9 & 馬 & $\mathrm{O}$ & 正 & 0 & $\begin{array}{c}\hat{\delta} \\
31\end{array}$ & 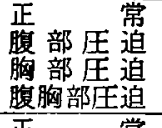 & $\begin{array}{r}8 \\
10 \\
8 \\
9 \\
15\end{array}$ & $\begin{array}{l}1200 \\
1100 \\
1250 \\
1200 \\
\end{array}$ & $\begin{array}{r}9600 \\
11000 \\
10000 \\
10800 \\
\end{array}$ & $\begin{array}{l}2.7 \\
2.2 \\
2.7 \\
2.4 \\
\end{array}$ & $\begin{array}{l}4.8 \\
4.0 \\
4.0 \\
3.7 \\
\end{array}$ & $\begin{array}{l}6200 \\
5700 \\
5000 \\
5000 \\
\end{array}$ \\
\hline 10 & 跌 & 0 & 昭 & O & $\begin{array}{c}\hat{\delta} \\
26\end{array}$ & 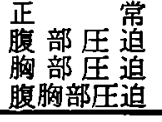 & $\begin{array}{l}15 \\
16 \\
18 \\
19 \\
\end{array}$ & $\begin{array}{l}410 \\
450 \\
400 \\
400 \\
\end{array}$ & $\begin{array}{l}6150 \\
6560 \\
7200 \\
7600 \\
\end{array}$ & $\begin{array}{l}1.5 \\
1.7 \\
1.5 \\
1.6 \\
\end{array}$ & $\begin{array}{l}2.5 \\
2.0 \\
1.8 \\
1.8 \\
\end{array}$ & $\begin{array}{l}3800 \\
3600 \\
3300 \\
3100 \\
\end{array}$ \\
\hline
\end{tabular}

手術後, 胸部手術患者では胸鄭の運動を, 腹部手 術患者では腹壁の運動をでるろだけ制限して手術創
の疼痛を軽减しようと努める。また手術創に強く包 帯をまいたり（胸帯，腹帯等），時に砂震を置いた 
りすることは，肺換気機能にどのように影牟をおよ ばすかをみるため, 腹部, 胸部を包帯で強く死迫し た場合の肺換気機能におよばす影譬を調查した。

\section{1. 調查症例と研究方法}

胸部に既往歴のない健康人10人に，腹部を圧迫し た場合，胸部を压迫した場合、腹部，胸部を同時に 王迫した各場合 の呼吸数，1回換気量，分時換気 量，投気時間，呼気時間，肺活聂の测定之，三栄測
器社製の胸囲型呼吸電極を用いての胸酣運動と腹塈 運動，および各場合の Pneumotachogram の記録 （日本光電社製）を行なった。

腹部压迫には肹のやや上部を包带で強く圧迫し， その上に胸囲型電極を装着し，胸部は圧迫せず直接 乳房のやや上部に胸囲型電極を装着比較した。胸部 圧迫には乳房のやや上部を包帯で強く圧迫しその上 に胸囲型電極を装着，腹部には直接胸囲型電㥛を装

図15 圧迫による肺換気榙能の变䡃

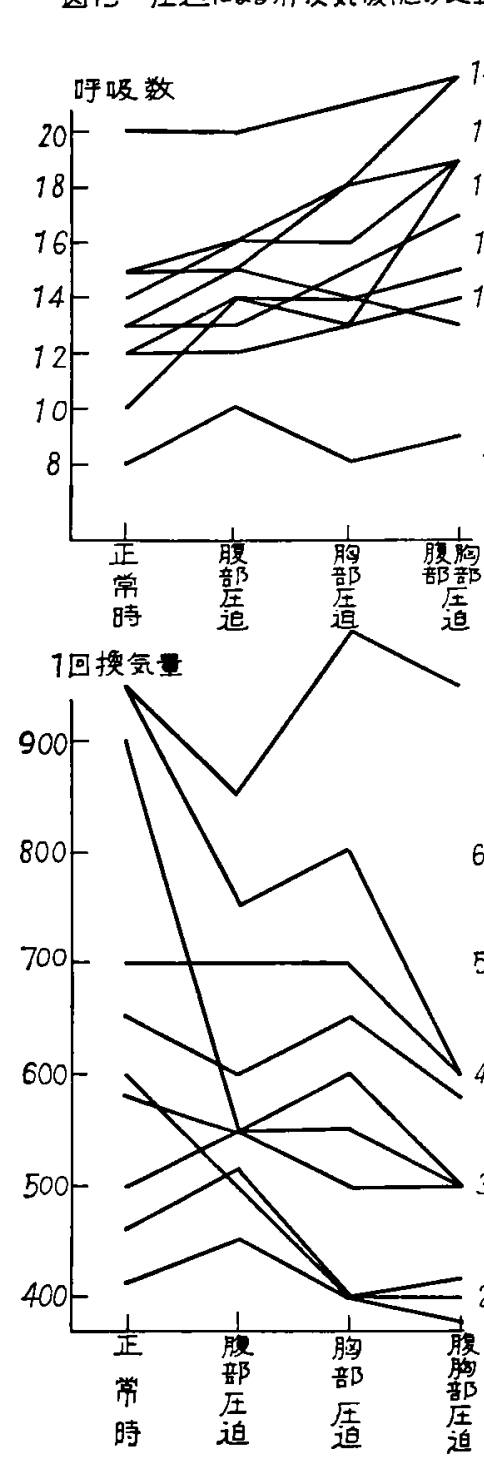

着し比較した。腹部胸部の同時圧迫には包帯で両部 を強く圧迫しその上に各々胸囲型電極を装着し日本 光電社製のポリレコーダーに接続し記録した。剆定 体位は背位で行なった。

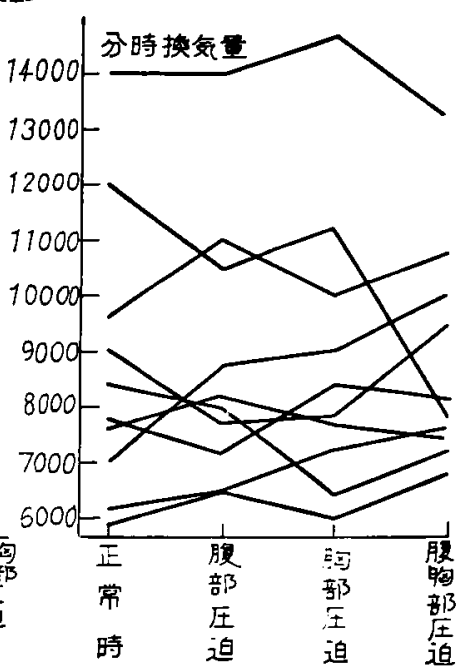

肺活量

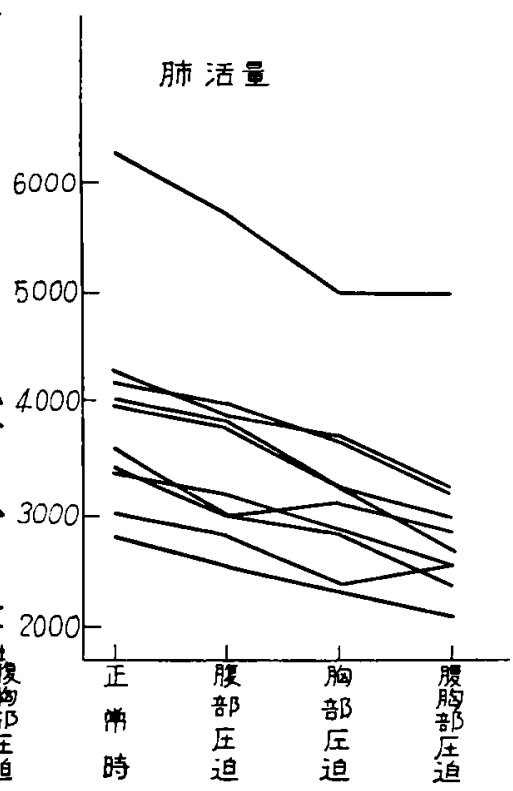

2. 成 績

呼吸数（表 5, 図15）

呼吸数は腹部圧迫を行なうと10例中の7例に增 加，不変 3 例で呼吸数の城少は 1 例ちなかった。胸 
部圧迫で: 9 例に増加, 不変 1 例でやはり呼吸数は 增加する傾向を示しだ。腹部、胸部同時圧迫では全 例に呼吸数の增加を認めた。健康人10人の压迫前の 呼吸数の平均は每分13.1回 $(8 \sim 20)$ であり, 腹部 圧迫時海分14.6回（10２0回）, 胸部圧迫時の 平均は毎分15回 ( 8 21回) であり, 腹部, 胸部同 時圧迫の場合の平均は毎分16.7回 ( $9 \sim 22$ 回) と順 次增加の傾向を示している。

1 回換気量 (表 5, 図15)

1 回换気量江腹部圧迫により10例中 7 例に减少を 認め, 不変 2 , 增加は 1 例であった。胸部圧迫によ 万 1 回換気量は 6 例海減少, 不変 3 例, 增加は 1 例 であっだ。腹部胸部同時に圧迫した場合，1回換気 量は10例中 8 例に減少を認め, 不変 2 例で増加は 1 例もなかった。压迫により 1 回換気量汁城少する傾 向を示した。健康人 10 例の圧迫前（正常時）の 1 回 換気量の平均は $709 \mathrm{cc}(460 \sim 1200 \mathrm{CC})$ で, 腹部圧迫 時の平均は 625cc (450 1100cc)で減少を示し, 胸 部圧迫時の平均はやはり $625 \mathrm{cc}(400 \sim 1250 \mathrm{cc}) て ゙$ 增 減はなく，腹部胸部同時に圧迫した場合の 1 回換気 量の平均は $566 \mathrm{ccc}(400 \sim 1200 \mathrm{CC})$ で腹部胸部圧迫時 に最も低下が認められた。

\section{分時換気量（表 5, 図15）}

分時换気量は腹部圧迫により10例中 5 例に增加, 4 例に減少を認め, 増加, 诚少はぼ同数であった。 胸部圧迫時には 7 例に增妿, 3 例に減少を認め, 腹 部, 胸部同時圧迫時には 6 例に増加，4例に減少を 認めた。健康人の圧迫前分時換気量の平均は8747CC (5980 14000CC) であり, 腹部圧迫時の平均は8851 cc. $(6500 \sim 14000)$, 胸部圧迫時の平均は $8845 \mathrm{cc}$ （60 $00 \sim 14700 \mathrm{CC})$, 腹部胸部圧迫時の分時換気量の平均 は8854cc（6800〜13200cC）で，分時換気量は腹部ま たは胸部圧迫によりはとんど変動を示っなかった。

吸気時間, 吸気時間 (表 5)

吸気時間は腹部圧迫により10例中 7 例に短縮し, 延長したのは 2 例であった。胸部圧迫時も同様に 7 例に短縮したが延長した症例は1例もなかった。腹 部胸部を同時に圧迫した場合には吸気時間は10例中 9 例に短縮し，延長したのは 1 例であった。 呼気時間は腹部圧迫時には10例中 7 例に短縮を。 2 例に延長を認めた。胸部圧迫時には10例中 8 例に 短縮，延長した症例は認められなかった。腹部胸部 同時圧迫時には10例の全例に短縮が㒛められた。

肺活量（表 5, 図15) ‘

腹部圧迫時の肺活量の変化は10例全例に減少を認
めた。胸部圧迫時, 腹部胸部同時圧迫時にも肺活量 は例外なく減少したが, 腹部胸部圧迫時の減少が最 も著明であった。即ち, 健康人10人の圧迫前の胡活 量の平均は3924CC（3000 6200cC）で，腹部圧迫時 の肺活量の平均は3589cc $(2600 \sim 5700 \mathrm{CC})$ に減 少 し, 胸部圧迫時の平均は3232Cc. (2300 5000 Cc) と さらに減少し, 腹部胸部同時圧迫時の平均は3034CC (2480 5000cC) と著減し, 肺活量の減少は, 腹部 胸部圧迫時に最も著明であった。

写真 1 匟迫による変化 正常人25才合

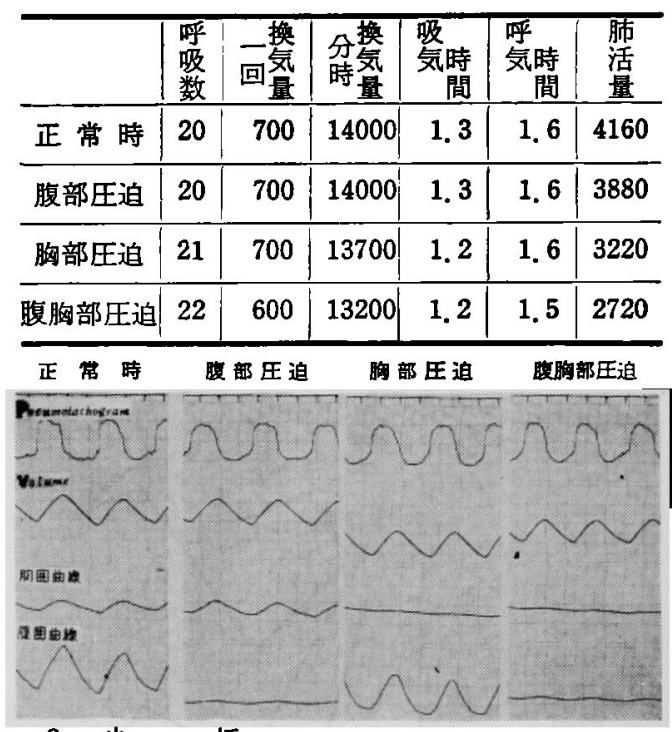

$$
\text { 3. 小 括 }
$$

腹部圧迫により呼吸数は大部分の症例で增加し， 堿少した症例はなかった。1 回換気量は過半数の症 例で成少を認めたが，分時換気量は減少，增加は ば同数であった。肺活量は全例に減少を認めた。と れは呼吸数の増加が 1 回換気量の减少を伴ない, 肺 換気の効率の面からは好ましくない。

胸部圧迫により呼吸数は腹部圧迫時よりもさらに 増加する傾向があり， 1 回換気量は半数以上に減少 を認め, 分時換気量仙やや增加する傾向を示した。 肺活量は全例に減少を認め, 堿少の程度は腹部圧迫 時より著明であっだ。胸部圧迫の場合も，腹部圧迫 と同様換気の効率は悪かった。

腹部，胸部を同時に圧迫した場合には，呼吸数は 前 2 者に比し著明に增加し，1回換気量ははば全例 に減少するが, 分時換気量は増加, 減少はほ同数で あった。肺活量は全例に減少し，減少の程度も前 2 


\section{者に比し最も著明であった。}

Pneumotachogram の Pattern は圧迫の前後 に大きな変化は認められなかった。（写真 1）

すなわち, 腹部, 胸部, 腹胸部圧迫の肺換気機能 におよばす影㖆は，腹胸部圧迫の場合が最も強く， 腹部圧迫では軽度である。したがって手術創の包帯 は肺換気面からみると，できるだけ䌅く，特に包带 が腹部胸部にわたるときは注意を要する。

V 手衍㓣の疼痛か肺換気機能および動脈血ガス分

\section{圧に及ほす影量}

手街後に手衔創の疼痛が呼吸運動を制限し低肺换 気に楩ることが街後肺合併应発生の大きな原因の一 つと考えられる。(1) 43198) 1051 そこで手洐創の疼痛 を除去する目的で鎮痛剂として塩酸阿片アルカロイ ド（オピアル）を使用した場合の肺換気機能および 動脈血ガス分圧に及ぼす影幚を調查した。

1. 調查症例亡研究方法

当利に入院し全身麻酔下で手術を行なった外科的

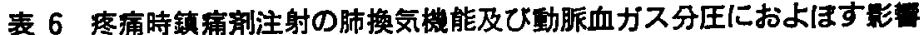

\begin{tabular}{|c|c|c|c|c|c|c|c|c|c|c|c|c|c|}
\hline 症 & 氏 & 珄 & $\begin{array}{l}\text { 診 断 名 } \\
\text { 手 }\end{array}$ & 疼痛 & 呼吸数 & 1 回 & $\begin{array}{r}\text { 子 時 } \\
\text { 奐気䄓 }\end{array}$ & $\begin{array}{l}\text { 吸気 } \\
\text { 時間 }\end{array}$ & $\begin{array}{l}\text { 呼気 } \\
\text { 時間 }\end{array}$ & $\mathrm{Po}_{2}$ & $\mathrm{Pco}_{2}$ & $\mathrm{pH}$ & 肺活量 \\
\hline 1 & $き 0$ & $\begin{array}{l}\text { 우 } \\
53\end{array}$ & 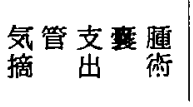 & (H & $\begin{array}{l}18 \\
36 \\
22\end{array}$ & $\begin{array}{l}300 \\
260 \\
300\end{array}$ & $\begin{array}{l}5400 \\
9360 \\
6600\end{array}$ & $\begin{array}{l}1.5 \\
0.7 \\
1.2\end{array}$ & $\begin{array}{l}1.8 \\
0.9 \\
1.5\end{array}$ & $\begin{array}{l}83 \\
85 \\
82\end{array}$ & $\begin{array}{l}37 \\
44 \\
38\end{array}$ & $\begin{array}{l}7.42 \\
7.46 \\
7.42\end{array}$ & $\begin{array}{l}800 \\
600 \\
850 \\
\end{array}$ \\
\hline 2 & 畠○ オ0 & $\begin{array}{l}\S \\
24\end{array}$ & 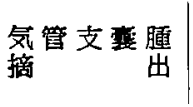 & ( & $\begin{array}{l}17 \\
23 \\
20\end{array}$ & $\begin{array}{l}240 \\
200 \\
250\end{array}$ & $\begin{array}{l}4000 \\
4300 \\
4500\end{array}$ & \begin{tabular}{l|}
1.4 \\
1.2 \\
1.2
\end{tabular} & $\begin{array}{l}2.1 \\
1.4 \\
1.8\end{array}$ & $\begin{array}{l}87 \\
98 \\
80\end{array}$ & $\begin{array}{l}36 \\
42 \\
35\end{array}$ & \begin{tabular}{l|}
7.34 \\
7.37 \\
7.36
\end{tabular} & $\begin{array}{l}800 \\
700 \\
950\end{array}$ \\
\hline 3 & 米O 正O & \begin{tabular}{l|}
5 \\
46
\end{tabular} & $\begin{array}{l}\text { 胃 潰 瘍 } \\
\text { 胃切除 B I }\end{array}$ & & $\begin{array}{l}27 \\
28 \\
16\end{array}$ & $\begin{array}{l}700 \\
450 \\
600\end{array}$ & $\begin{array}{r}13500 \\
12600 \\
9600\end{array}$ & \begin{tabular}{l|}
1.2 \\
1.0 \\
1.1
\end{tabular} & \begin{tabular}{l|}
0.8 \\
1.0 \\
1.8
\end{tabular} & $\begin{array}{l}78.2 \\
87 \\
68\end{array}$ & $\begin{array}{l}43.5 \\
45.5 \\
52\end{array}$ & $\begin{array}{l}7.37 \\
7.38 \\
7.36\end{array}$ & $\begin{array}{l}1400 \\
1200 \\
1600\end{array}$ \\
\hline 4 & 武O & $\begin{array}{c}5 \\
60\end{array}$ & $\begin{array}{l}\text { 胃 } \\
\text { 胃切除 }\end{array}$ & $\stackrel{(-}{(H+}$ & $\begin{array}{l}20 \\
26 \\
19\end{array}$ & $\begin{array}{l}480 \\
450 \\
340\end{array}$ & $\left|\begin{array}{r}9600 \\
11600 \\
6460\end{array}\right|$ & $\begin{array}{l}1.2 \\
1.0 \\
1.4\end{array}$ & \begin{tabular}{l|}
1.8 \\
1.3 \\
1.6
\end{tabular} & $\begin{array}{l}92 \\
98 \\
90\end{array}$ & $\begin{array}{l}34 \\
30 \\
36\end{array}$ & $\begin{array}{l}7.34 \\
7.32 \\
7.32\end{array}$ & $\begin{array}{r}1000 \\
700 \\
1100\end{array}$ \\
\hline 5 & 佳○ 彦O & \begin{tabular}{c|}
$\hat{\delta}$ \\
42
\end{tabular} & $\begin{array}{c}\text { 十二指腸潰愓 } \\
\text { 胃切除 B I }\end{array}$ & & $\begin{array}{l}16 \\
22 \\
18\end{array}$ & $\begin{array}{l}520 \\
460 \\
480\end{array}$ & $\begin{array}{r}8320 \\
10120 \\
8640\end{array}$ & $\begin{array}{l}1.5 \\
1.2 \\
1.5\end{array}$ & $\begin{array}{l}2.2 \\
1.5 \\
1.3\end{array}$ & $\begin{array}{r}90 \\
102 \\
94\end{array}$ & $\begin{array}{l}36 \\
32 \\
37\end{array}$ & $\begin{array}{l}7.38 \\
7.38 \\
7.32\end{array}$ & $\begin{array}{l}1400 \\
1300 \\
1400\end{array}$ \\
\hline 6 & 岩○富○○ & $\begin{array}{c}\hat{\delta} \\
62\end{array}$ & $\begin{array}{ll}\text { 胃 } & \text { 癌 } \\
\text { 团切除 B I }\end{array}$ & $\begin{array}{l}(\overline{-}) \\
(+)\end{array}$ & $\begin{array}{l}18 \\
23 \\
20\end{array}$ & $\begin{array}{l}420 \\
430 \\
360\end{array}$ & $\begin{array}{l}7600 \\
8960 \\
7200\end{array}$ & \begin{tabular}{l|}
1.5 \\
1.4 \\
1.2
\end{tabular} & $\begin{array}{l}1.8 \\
1.5 \\
1.8\end{array}$ & $\begin{array}{l}84 \\
78 \\
79\end{array}$ & $\begin{array}{l}32 \\
32 \\
31\end{array}$ & $\begin{array}{l}7.30 \\
7.30 \\
7.28\end{array}$ & $\begin{array}{l}1700 \\
1700 \\
1800\end{array}$ \\
\hline 7 & 友O龟OO & $\begin{array}{c}\text { 우 } \\
68\end{array}$ & $\begin{array}{ll}\text { 胃 } & \text { 癌 } \\
\text { 胃 全 摘 }\end{array}$ & ( & $\begin{array}{l}19 \\
24 \\
23\end{array}$ & $\begin{array}{l}240 \\
160 \\
180 \\
\end{array}$ & $\begin{array}{l}4000 \\
3800 \\
4300\end{array}$ & $\begin{array}{l}1.4 \\
1.2 \\
1.3\end{array}$ & $\begin{array}{l}1.7 \\
1.3 \\
1.3\end{array}$ & $\begin{array}{l}86 \\
96 \\
92\end{array}$ & $\begin{array}{l}42 \\
44 \\
38\end{array}$ & $\begin{array}{l}7.40 \\
7.42 \\
7.42\end{array}$ & $\begin{array}{l}800 \\
700 \\
900\end{array}$ \\
\hline 8 & 若O 朝O & $\begin{array}{c}\hat{} \\
55\end{array}$ & $\begin{array}{ll}\text { 胃 } & \text { 癌 } \\
\text { 胃 腸 吻 } & \text { 合 }\end{array}$ & & $\begin{array}{l}14 \\
16 \\
14 \\
\end{array}$ & $\begin{array}{l}320 \\
300 \\
320 \\
\end{array}$ & $\begin{array}{l}4600 \\
4800 \\
4300\end{array}$ & $\begin{array}{l}1.5 \\
1.6 \\
1.3\end{array}$ & $\begin{array}{l}2.0 \\
2.0 \\
2.1\end{array}$ & $\begin{array}{l}80 \\
84 \\
70\end{array}$ & $\begin{array}{l}32 \\
25 \\
30\end{array}$ & $\begin{array}{l}7.34 \\
7.36 \\
7.36\end{array}$ & $\begin{array}{l}1800 \\
1800 \\
1800\end{array}$ \\
\hline 9 & 横 $\mathrm{O}$ & $\begin{array}{c}\hat{\delta} \\
26\end{array}$ & $\begin{array}{l}\text { 十二指腸漬瘍 } \\
\text { 胃切除 B I }\end{array}$ & $(-$ & $\begin{array}{l}16 \\
20 \\
18\end{array}$ & $\begin{array}{l}320 \\
300 \\
400\end{array}$ & $\begin{array}{l}5120 \\
6000 \\
7200\end{array}$ & $\begin{array}{l}1.4 \\
1.4 \\
2.0\end{array}$ & $\begin{array}{l}2.3 \\
1.6 \\
3.0\end{array}$ & $\begin{array}{l}88 \\
90 \\
80\end{array}$ & $\begin{array}{l}38.5 \\
34 \\
36\end{array}$ & \begin{tabular}{l|l|}
7.37 \\
7.39 \\
7.30
\end{tabular} & $\begin{array}{l}2100 \\
2000 \\
2000\end{array}$ \\
\hline 10 & 神 $\mathrm{O}$ 米O & $\begin{array}{c}9 \\
65\end{array}$ & 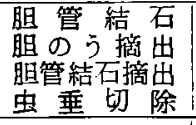 & $\zeta$ & $\begin{array}{l}24 \\
30 \\
23\end{array}$ & $\begin{array}{l}350 \\
400 \\
400\end{array}$ & $\begin{array}{r}8400 \\
12000 \\
9200\end{array}$ & $\begin{array}{l}1.0 \\
0.7 \\
0.7\end{array}$ & $\begin{array}{l}1.5 \\
1.2 \\
1.7\end{array}$ & $\begin{array}{l}105 \\
108 \\
102\end{array}$ & $\begin{array}{l}36 \\
31 \\
38\end{array}$ & $\begin{array}{l}7.38 \\
7.43 \\
7.43\end{array}$ & $\begin{array}{r}1100 \\
950 \\
1200\end{array}$ \\
\hline 11 & 一O 輝 $\bigcirc$ & $\begin{array}{c}\hat{\delta} \\
25\end{array}$ & $\begin{array}{lr}\text { 胆 } & \text { 石 } \\
\text { 胆のう摘出 }\end{array}$ & $\begin{array}{l}(-) \\
(-1+)\end{array}$ & $\begin{array}{l}18 \\
25 \\
16\end{array}$ & $\begin{array}{l}500 \\
400 \\
500\end{array}$ & $\begin{array}{r}9000 \\
10000 \\
8000 \\
\end{array}$ & $\begin{array}{l}1.5 \\
0.8 \\
1.5\end{array}$ & $\begin{array}{l}1.7 \\
1.2 \\
1.8\end{array}$ & $\begin{array}{c}97.1 \\
106 \\
98\end{array}$ & $\begin{array}{l}36 \\
32 \\
35\end{array}$ & $\begin{array}{l}7.37 \\
7.38 \\
7.33\end{array}$ & $\begin{array}{l}1200 \\
1000 \\
1100\end{array}$ \\
\hline 12 & 佐○間陽○ & $\begin{array}{c}+9 \\
27\end{array}$ & $\begin{array}{l}\text { 慢 性 便 秘 } \\
\text { 半㑡結腸切除 }\end{array}$ & $\begin{array}{l}(-) \\
(+14)\end{array}$ & $\begin{array}{l}16 \\
21 \\
19\end{array}$ & $\begin{array}{l}280 \\
250 \\
300\end{array}$ & $\begin{array}{l}4600 \\
5100 \\
5600\end{array}$ & $\begin{array}{l}1.2 \\
1.2 \\
1.3\end{array}$ & $\begin{array}{l}1.5 \\
1.7 \\
1.8\end{array}$ & $\begin{array}{l}90 \\
95 \\
88\end{array}$ & $\begin{array}{l}40 \\
41 \\
49\end{array}$ & $\begin{array}{l}7.40 \\
7.40 \\
7.38\end{array}$ & $\begin{array}{r}1000 \\
900 \\
1100\end{array}$ \\
\hline 13 & 星○ み○ & $\begin{array}{l}\text { 우 } \\
65\end{array}$ & $\begin{array}{l}\text { 慢 性 便 秘 } \\
\text { 半側結腸切除 }\end{array}$ & $\begin{array}{l}(-) \\
( \pm)\end{array}$ & $\begin{array}{l}16 \\
20 \\
18\end{array}$ & $\begin{array}{l}320 \\
270 \\
270\end{array}$ & $\begin{array}{l}5120 \\
5300 \\
4800\end{array}$ & $\begin{array}{l}1.5 \\
1.3 \\
1.3\end{array}$ & $\begin{array}{l}2.2 \\
1.7 \\
2.0\end{array}$ & $\begin{array}{l}88 \\
90 \\
82\end{array}$ & $\begin{array}{l}34 \\
40 \\
43\end{array}$ & $\begin{array}{l}7.36 \\
7.36 \\
7.32\end{array}$ & $\begin{array}{l}800 \\
800 \\
900\end{array}$ \\
\hline
\end{tabular}




\begin{tabular}{|c|c|c|c|c|c|c|c|c|c|c|c|c|c|}
\hline 14 & 高○美○枝 & $\begin{array}{l}+9 \\
19\end{array}$ & 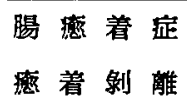 & $\left(-\frac{\pi}{4}\right)$ & $\begin{array}{l}16 \\
20 \\
17\end{array}$ & $\begin{array}{l}340 \\
290 \\
320\end{array}$ & $\begin{array}{l}\mathbf{5 5 0 0} \\
\mathbf{5 7 0 0} \\
\mathbf{5 4 0 0}\end{array}$ & $\begin{array}{l}1.5 \\
1.4 \\
1.2\end{array}$ & $\begin{array}{l}2.2 \\
1.6 \\
1.5\end{array}$ & $\begin{array}{l}84 \\
85 \\
72\end{array}$ & $\begin{array}{l}39 \\
39 \\
41\end{array}$ & $\begin{array}{l}7.43 \\
7.41 \\
7.40\end{array}$ & $\begin{array}{l}1900 \\
1700 \\
1800\end{array}$ \\
\hline 15 & 滝○ 保O & $\begin{array}{r}+9 \\
25\end{array}$ & 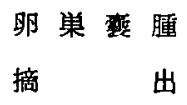 & \{ & $\begin{array}{l}14 \\
15 \\
19\end{array}$ & $\begin{array}{l}380 \\
300 \\
360\end{array}$ & $\begin{array}{l}5300 \\
5700 \\
5400\end{array}$ & $\begin{array}{l}2.0 \\
1.4 \\
1.9\end{array}$ & $\begin{array}{l}2.4 \\
1.7 \\
2.2\end{array}$ & $\begin{array}{l}86 \\
88 \\
88\end{array}$ & $\begin{array}{l}4 \\
4\end{array}$ & $\begin{array}{l}7.32 \\
7.34 \\
7.34\end{array}$ & $\begin{array}{l}1800 \\
1700 \\
1800\end{array}$ \\
\hline 16 & 平 0 & $\begin{array}{l}\uparrow \\
24\end{array}$ & $\begin{array}{l}\text { 虫垂 炎 } \\
\text { 虫垂切 除 }\end{array}$ & $\begin{array}{l}(-) \\
(-)\end{array}$ & $\begin{array}{l}15 \\
17 \\
14\end{array}$ & $\begin{array}{l}400 \\
380 \\
360\end{array}$ & $\begin{array}{l}6000 \\
6460 \\
5040\end{array}$ & $\begin{array}{l}1.8 \\
1.6 \\
2.0\end{array}$ & $\begin{array}{l}2.2 \\
1.9 \\
2.4\end{array}$ & $\begin{array}{l}90 \\
85 \\
88\end{array}$ & $\begin{array}{l}3 \\
3\end{array}$ & $\begin{array}{l}7.36 \\
7.36 \\
7.34\end{array}$ & $\begin{array}{l}2300 \\
2300 \\
2000\end{array}$ \\
\hline 17 & 中O 正O & $\begin{array}{c}5 \\
19\end{array}$ & $\begin{array}{l}\text { 鼠徍ヘルニア } \\
\text { 根治手 原 }\end{array}$ & $\begin{array}{l}(-) \\
(H)\end{array}$ & $\begin{array}{l}18 \\
24 \\
24\end{array}$ & $\begin{array}{l}310 \\
240 \\
200\end{array}$ & $\begin{array}{l}5700 \\
5600 \\
4900\end{array}$ & $\begin{array}{l}1.2 \\
1.2 \\
1.0\end{array}$ & $\begin{array}{l}1.3 \\
1.3 \\
\text { I. } 5\end{array}$ & $\begin{array}{l}82 \\
78 \\
78\end{array}$ & 3 & $\begin{array}{l}7.30 \\
7.34 \\
7.32\end{array}$ & $\begin{array}{l}2100 \\
2100 \\
2200\end{array}$ \\
\hline
\end{tabular}

諸疾息者17例（表 6）について，手術が終了し麻醉 から覚醒しまだ疼を訴えない時期と，その後明碓 に疼痛を訴えた時期と, 鎮痛剂注射後(程酸阿片ア ルカロイド（オピアル） $0.4 \mathrm{mg} / \mathrm{kg}$ ）の疼痛が軽减 または消失した時期とに次の項目について測定を行 なった。

(1)呼吸数, 吸気時間, 呼気時間

(2)Wright の流量計を用いて 1 回換気量，分時換気 㟟

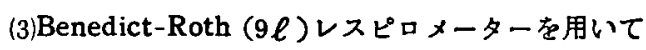
肺活量

(4)三栄測器社製の胸囲型雨極を乳房の高さと臍の高 さの2ヶ所に着䒾し，胸壁運動と腹壁運動を日本 光電社製のポリレコーダーに記録

(5)Pneumotachogramを記箓

(6)前章と同様の方法で動脈血 $\mathrm{Po}_{2}, \mathrm{PCO}_{2}, \mathrm{pH}$ の測 定。（表6）

2. 成 綡

呼吸数（表 6・図16）

疼痛時には呼吸数は17例全例に増加し, 鎮痛剂注 射後の疼痛軽娍または消失時には17例中の16例に呼 吸数の減少を認めた。すなわち術後，休酔から賞醒 し疼痛を訴えないときの呼吸数の平均は每分17.5回 (14〜25回) であるが，疼痛を訴えた時期では平均 毎分22.6回（16〜36回）に增加し，鎮痛剤注射後の 鎮痛時には呼吸数の平均は毎分18.4回（14２4回） に減少しだ。

1 回換気量（表 6・図16）

疼痛時に 1 回換気量は17例中の15例に減少し, 增 加は 2 洌であった。鎮痛剤注射後の鎮痛時には 1 回 段気量の増加は17例中の11例, 減少 4 例, 不变 2 例 であった。衡後麻酔から覚醒してまだ疼痛を訴えな い時期の 1 回換気量の平均は377.6cc（240～700cc） であり, 疼痛時には 325 Cc $(160 \sim 460 \mathrm{CC})$ に減少
し，跣痛剤注射後鎮痛時には350Ca（180〜 600CC） で疼痛時よりは增加していた。

\section{分時換気量（表 6・图16）}

疼痛時には分時換気量は17例中の14例に增加を認 め, 减少は 3 例であった。蹎痛郕这射後の疼痛消失 時には分時換気量は17例中13例に減少，増加は4 例 であった。術後磨酔から覚醒してまだ疼痛を訴えな い時期の分時換気量の平均は6532.9cc(4000 13500 ca）であり，疼痛を訴えた時期の平均は $7237.6 \mathrm{cc}$ (3800 12600CC) に増加しており, 鎮痛剂注射後の 鎮痛時では平均6288CC（4300〜9600CC）で疼痛時よ り減少している。

吸気時間および呼気時間（表 6)

疼痛時には吸気時間は17例中の12例に短縮を，不 変 4 例, 延長 1 例であり, 蹎痛䘞注射後の㒹痛時に は吸気時間は17例中の10例に延長を，不変 2 例，短 縮 5 例であった。術後まだ疼痛を訴えない時期の吸 気時間の平均は 1.43 秒 $(1.0 \sim 2.0)$ であり, 疼痛を 訴える時期では平均1.20秒 $(0.7 \sim 1.6)$ であり, 鎮 痛剤注射後では平均 1.4 秒（0.7〜2.0）であった。

呼気時間は疼痛時には17例中の14例に短縮を，不 変 1 例，延長 2 例であった。鎮痛剂注射後の鎮痛時 には17例中の15例に呼気時間の延長を, 不変 1 例， 短縮 1 例であった。少後疼痛を訴えない時期の呼気 時間の平均は 1.9 秒 $(0.8 \sim 2.4)$ であり, 疼痛時の 平均は 1,5秒( 0.9 2.0) であり, 鎮痛剂注射後の 平均は 1.9秒 $(1.5 〜 3.0)$ であった。

肺活量（表 $6 \cdot$ 図16）

肺活量は疼痛時には, 減少 11 例, 不変 6 例で增加 は1例もなかった。鎮痛剂注射後の疼痛の消失時に 肺活量は17例中の14例に增加し, 不変は 2 例, 減少 はわずか 1 例であった。

術後疼痛を訴えない時期の肺活量の平均は1412CC (800〜2300CC) であり，疼痛時には平均 $1302.9 \mathrm{CC}$ 


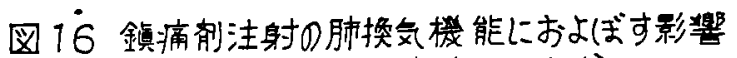

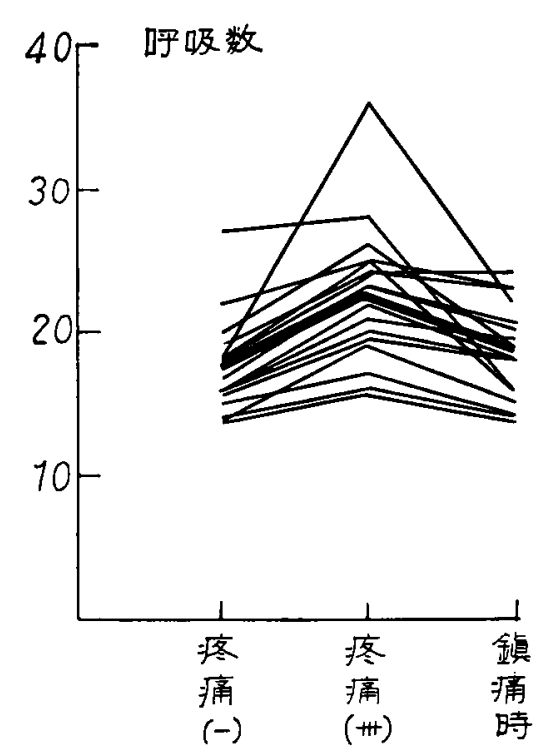

（太線は平均值）

c. 分時換気量
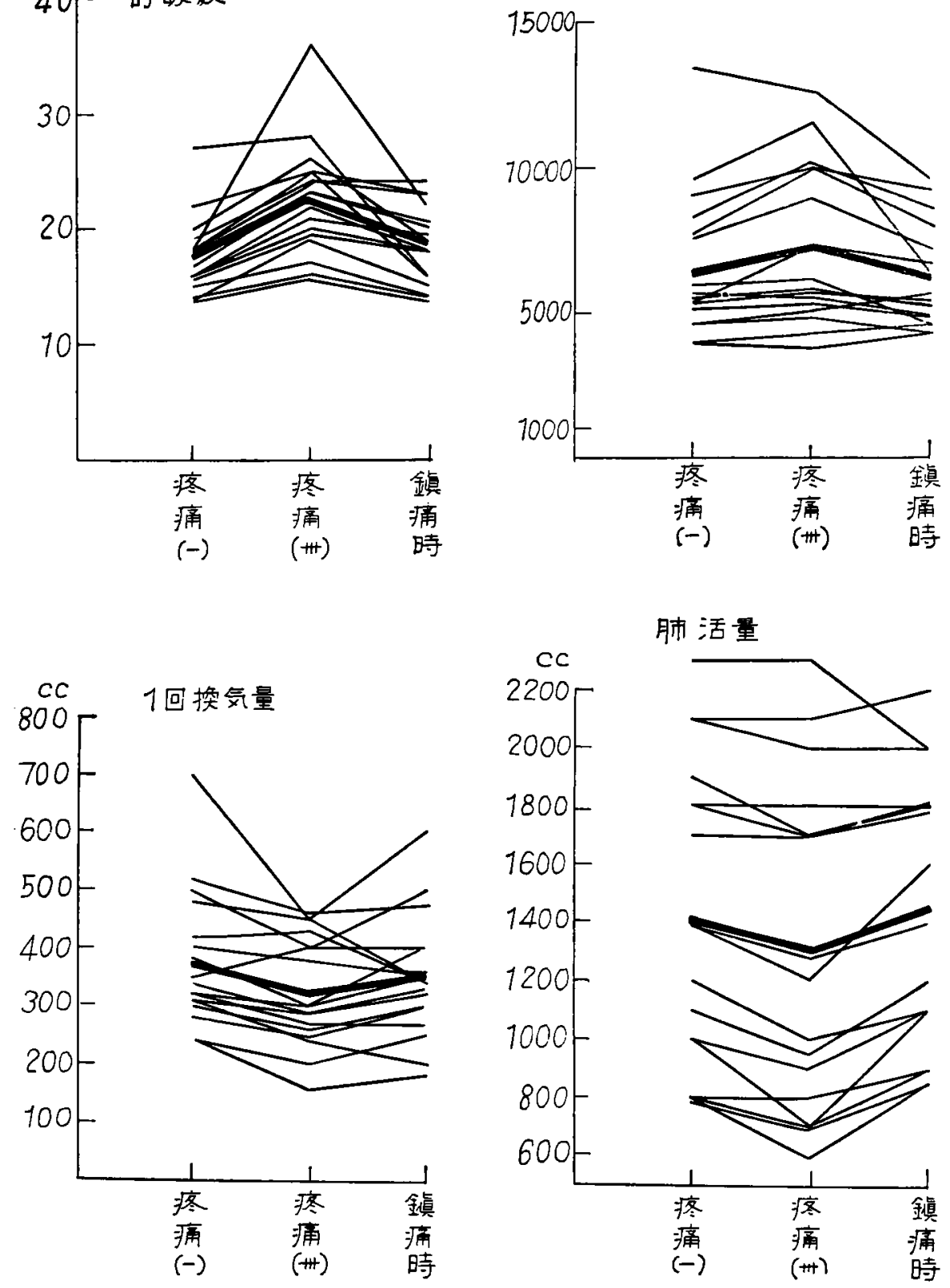

（600 2300cC）に減少しており，鎮痛刘注射後の鎮 痛時では肺活量の平均は $1441 \mathrm{Cc}$ (850 2200CC)に 増加していた。

動脈血ガス分压及び $\mathrm{pH}$ (表 6・図17）

疼痛を訴えた時期に $\mathrm{Po}_{2}$ の上昇は17例中14例で， 減少は 3 例であり，疼痛時には $\mathrm{Po}_{2}$ が上昇する㑯向

が認められた。鎮痛剂の注射により, 疼痛の消失し た時期では， $\mathrm{Po}_{2}$ は17例中の13例に低下を認め, 上 昇は 2 例, 不变 2 例で, 鎮痛時には $\mathrm{Po}_{2}$ の低下する 傾向が認められだ。術後麻醉から覚醒してまだ炵痛 を訴えない時期の $\mathrm{Po}_{2}$ の平均は $87.7 \mathrm{mmHg}$ ( 78 $106 \mathrm{mmHg}$ ) であるが, 疼痛時には平均 $91.4 \mathrm{mmHg}$ 
（78 109mmHg）に上昇し，鎮痛剤注射後の鎮痛 時には平均 $84.2 \mathrm{mmHg}(68 \sim 103 \mathrm{mmHg})$ と再び低 下する傾向を示しだ。

$\mathrm{Pco}_{2}$ (表 6. 図17)

疼痛を訴えた時期に $\mathrm{Pco}_{2}$ の低下は 17例 中の 9 例, 增加は 6 例, 不変 2 例で, 疼痛時には約過半数 に $\mathrm{PcO}_{2}$ の減少を認めた。鎮痛郕注射後の鎮痛時で は $\mathrm{Pco}_{2}$ は17例中の13例に増加, 減少は 4 例であっ た。術後の無痛時の $\mathrm{Pco}_{2}$ の平均は $37.0 \mathrm{mmHg}$ (32 $\sim 44 \mathrm{mmHg}$ ) であるが，疼痛時には平均 $36.7 \mathrm{~mm}$ $\mathrm{Hg}(25 \sim 46 \mathrm{mmHg})$ とわずか低下し, 鎮痛郕注 射後の鎮痛時では平均 $38.9 \mathrm{mmHg}(30 \sim 52 \mathrm{mmHg})$ と再び增加する傾向を示した。

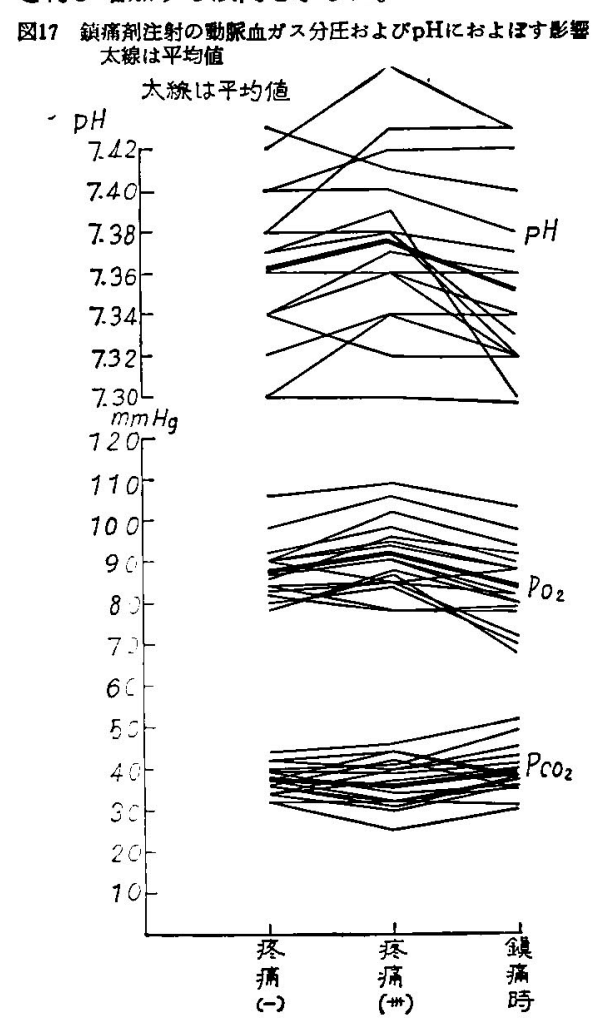

$\mathrm{pH}$ (表 6, 図17)

疼痛時には $\mathrm{pH}$ は17例中の10例に上昇し，不変 5 例, 娍少 2 例であり約半数以上に $\mathrm{pH}$ の上昇を記め た。㒹痛洔 $\mathrm{pH}$ の低下は17例中 12 例で, 上昇は 1 例 もなく，鎮痛㓮の使用により $\mathbf{p H}$ は低下する傾向を 示した。

临後無痛時の $\mathrm{pH}$ の平均は 7.363 (7.30〜7.43) であり, 疼痛時には平均7.376 (7.30〜743) とやゃ 上昇し，鎮痛削注射後の鎮痛時では平均7.353(7.30
〜7.43）と低下する傾向を示した。

3, 小 括

手術創の疼痛之胡換気機能の関係は古くから注目 されていたが，従来は主として肺活量について論し られてきた。疼痛時には多くの場合浅く速い呼吸と なりそのため吸気時間, 呼気時間はともに短縮し, 1 回換気量は減少する。しかし分時換気量は呼吸数 の增加によって補なわれ, むしろ增加する傾向を示 し, 肺活量は減少する傾向を示した。動脈血 $\mathrm{Po}_{2}$ は 疼痛時に増加し, $\mathrm{Pco}_{2}$ は低下, $\mathrm{pH}$ は上昇する傾 向を示した。鎮痛沜注射後の疼痛が軽減または消失 した時期では, 呼吸数はほば全例に減少し吸気時 間, 呼気時間はとも泟長し, 深くおそい呼吸型を 示し, 1 回換気量は増加するが, 分時換気量は減少 する傾向を示し, 胡活量は大半の症例で增加する㑯 向を示した。

動脈血 $\mathrm{Po}_{2}$ は頡痛時には減少し, 一方 $\mathrm{Pco}_{2}$ は增 加する傾向を示し， $\mathrm{pH}$ は低下したがこれら変動の すべては正常值範团内での変動であり, しかも鎮痛 時の各值が㸓後の疼痛苍訴えない時期のそれとはは 同值であることから鎮痛剤の注射が動脈血ガス分压 に悪影響を及ばしているとは考えられない。Pneumotachogram の型は無痛時, 疼痛時, 鎮痛剂注射 後の鎮痛時に著明な変化は認められないが, 腹壁運 動と胸壁運動の波型をみると（写真2，3）疼痛時に は胸壁運動の明らかな抑制がみられ，鎮痛時にはそ の抑制が解除されるととがみられだ。

\section{写真 2}

鎮痛剂注射の影震

症例10. 65才䏣のう摘出術

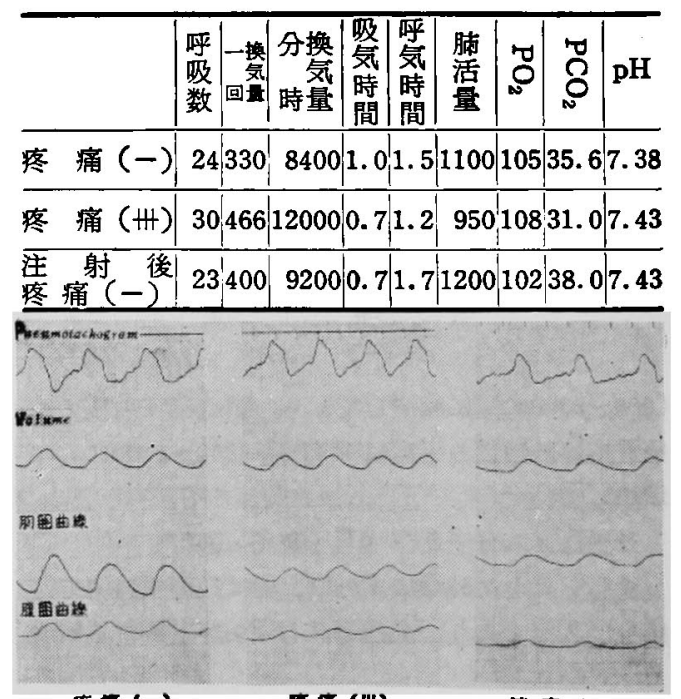


写莫 3 鎮痛剂注射の晨雾

症例11. 25才果胆のう摘出術

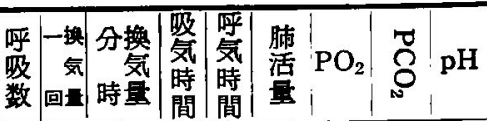

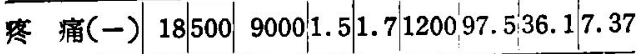

疼痛(卅) $25400_{1}^{\prime} 10000^{\prime} 0.81 .21000106{ }^{\prime} 31.97 .38$

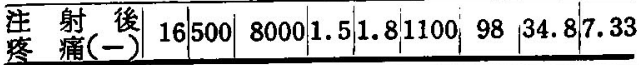

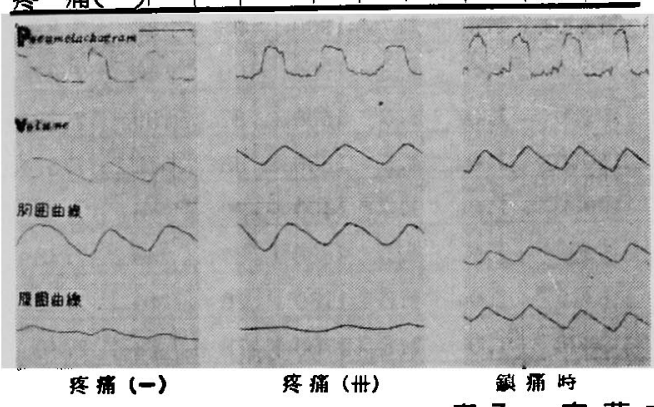

表 7. 㖖藤式二重管の影露
すなわち，手術後の疼痛にたいして，適当量の鎮痛

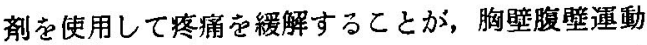
を充分に行なわし得るので，肺換気機能によい結果 をおよはすす。

VI 斉藤式二重管の肺換気機能およひ動脈血ガス分

\section{圧におよほす影幚}

当教室では胃手㹐患者には routin として齐藤式 二重管を経尊的に㨂入し，外管は残胃内に，内管は 空腸上部に留置し，外管は術後自然排気があるまで 周内容の排除を行ない，内管からは強力に経晹栄養 を行なっているが，術後に経勫的に Tube を插入 しておくとと法，肺換気機能を障碍し，街後肺合并 症を招来しやすいと主張する報告もある。 こてで斉 藤式二重管の扱入が, 術後肺換気機能および動脈血 ガス分圧に影響をなよばすか否かる調查した。

\section{1. 調查症例}

当外科で手術を行なった胃疾㭧13例と胆のう摘出

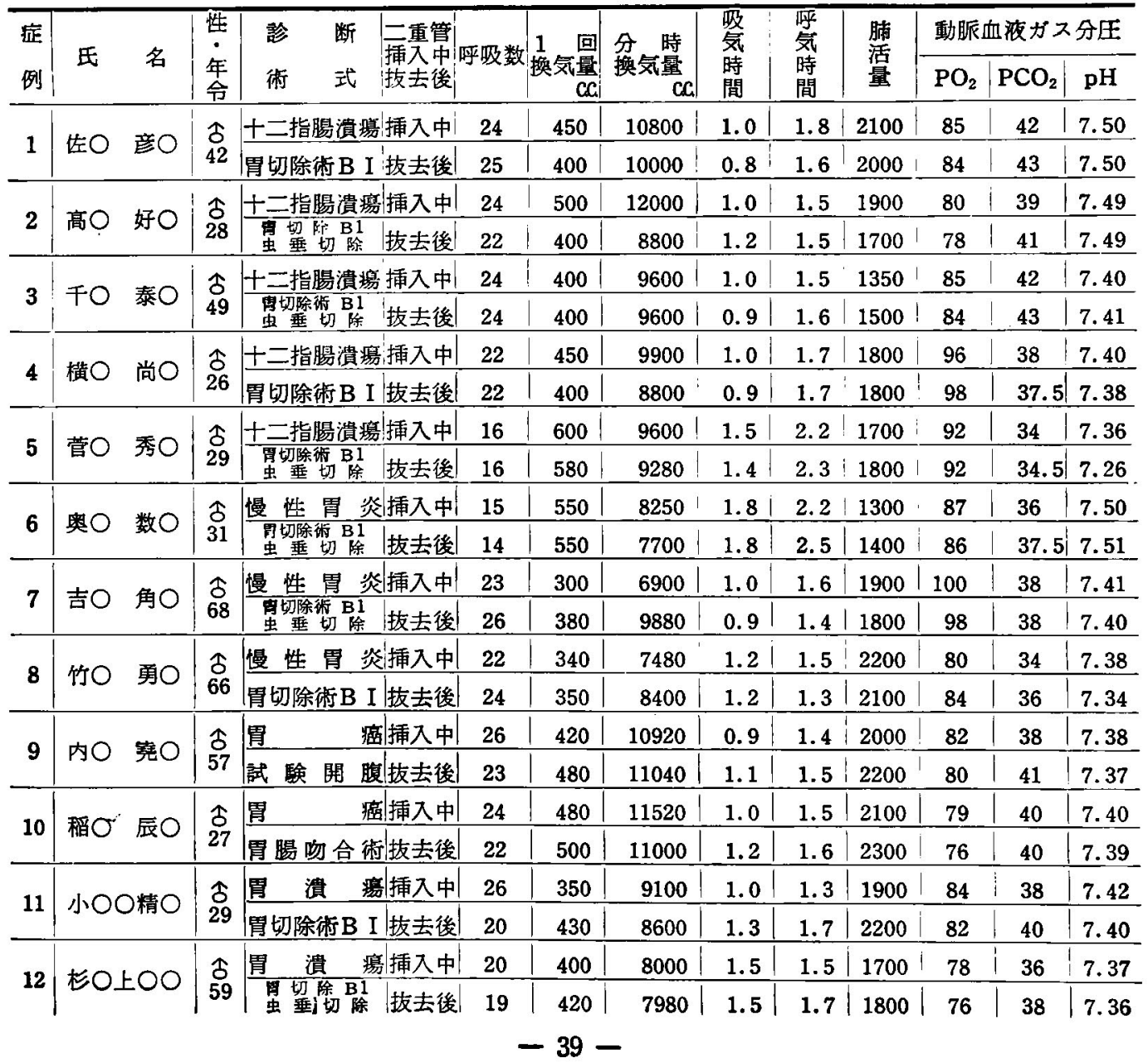




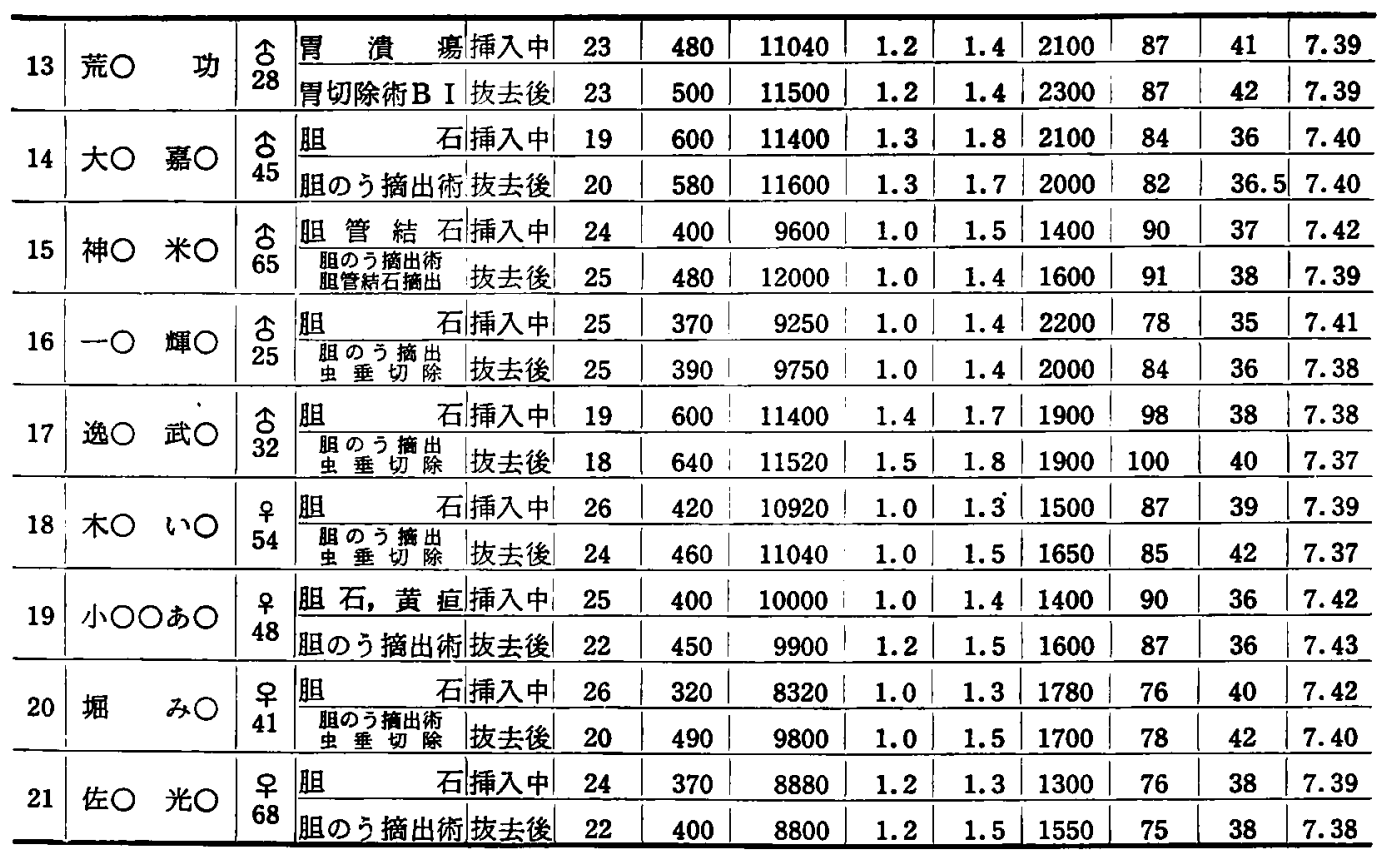

患者 8 例の合計21例（表7）について，術後 1 日に 二重管が挿入してある状態で呼吸数，1回換気量， 分時換気量，吸気時間，呼気時間，肺活量，呼吸気 速曲線, 動脈血ガス分圧および $\mathrm{pH}$ を前望と同様の 方法で测定し，その後二重管を抜去し，30分後に同 一項目について测定を行ない, 二重管の挿入されて いる時と，抜去後とを比較した。

2. 成嚗 (表 7 . 図18)

呼吸数 (图18)：

二重管の抜去により呼吸数の増加は 5 例，減少 11 例，不変 5 例であった。二重管捕入中の呼吸数の平 均は毎分22.7回（15〜26/分)であり，抜去後30分の 乎吸数の平均は毎分21.7回 (14〜26/分)であり，呼 吸数は二重管の抜去により平均毎分 1 回の減少をみ た。しかし個々の症例についてみると，症例11，症 例20，の如く，二重管の抜去が明らかに呼吸数の減 少をきたした症例も認められた。

1 回換気量：(図18)

二重管の抜去により1回換気量が増加したもの14 例，娍少したもの 5 例，不変 2 例であった。二重管 挿入中の 1 回換気量注平均 $438 \mathrm{cc}$ (300 600 ca) て あり，抜去後30分の 1 回換気量の平均は460 Cc (350 〜640CC）で，抜去後にわずかながら増加を䍿めた。 分時換気量：（図18）

二重管の挍去により，分時換気量の增加は10例， 減小は10例, 不変 1 例で, 増加, 減少は同数であっ
た。二重管抙入中の 分時 換気 量の平均は $9756 \mathrm{cc}$ (6900〜12000CC）であり，抜去後30分の分時換気量 の平均は9857cc（7700 12000Cc）で, 二重管の抜去 により分時換気量は約 $100 \mathrm{cc}$ 增加した。

吸気時間, 呼気時間：（表 7)

二重管の抜去により吸気時間の延長したものは 6 例，短縮したもの 5 例，不变10例であった。二重管 挿入中の吸気時間の平均は 1.1 秒 $(0.9 \sim 1.8$ 秒)で あり，拉去後30分の吸気時間の平均は1.2犁（0.8〜 1.8秒)で二重管の抜去により，昅気時間はほば不 変であった。

呼気時間は二重管の掖去により延長したち12例， 短縮は 5 例，不変 4 例であった。二重管搜入中の呼 気時閪の平均は1.56秒 $(1.3 \sim 2.5$ 秒) であり，抜去 後30分の呼気時間の平均は1.62秒 $(1.3 \sim 2.5$ 秒) で 两者の間にははとんど差異を認めなかった。

肺活量 : (図18)

二重管の抜去により䐈活量の増加は12例，減少は 7 例, 不変 2 例であった。二重管挿入中の肺活量の 平均は1792Cc（1300 2200Cc）であり，技去後30分 の肺活量の平均は1852cc（1400２300Cc）で，肺活 量は二重管の抜去により平均60cc,の増加が認められ た。

動脈血ガス分圧および $\mathrm{pH}$ (表 7, 図19）

二重管の抜去により動脈血 $\mathrm{Po}_{2}$ の増加は 6 例, 減 少は12例，不変 2 例であった。二重管挿入中の $\mathrm{Po}_{2}$ 


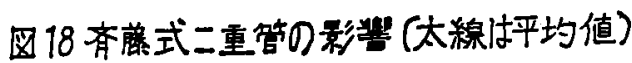
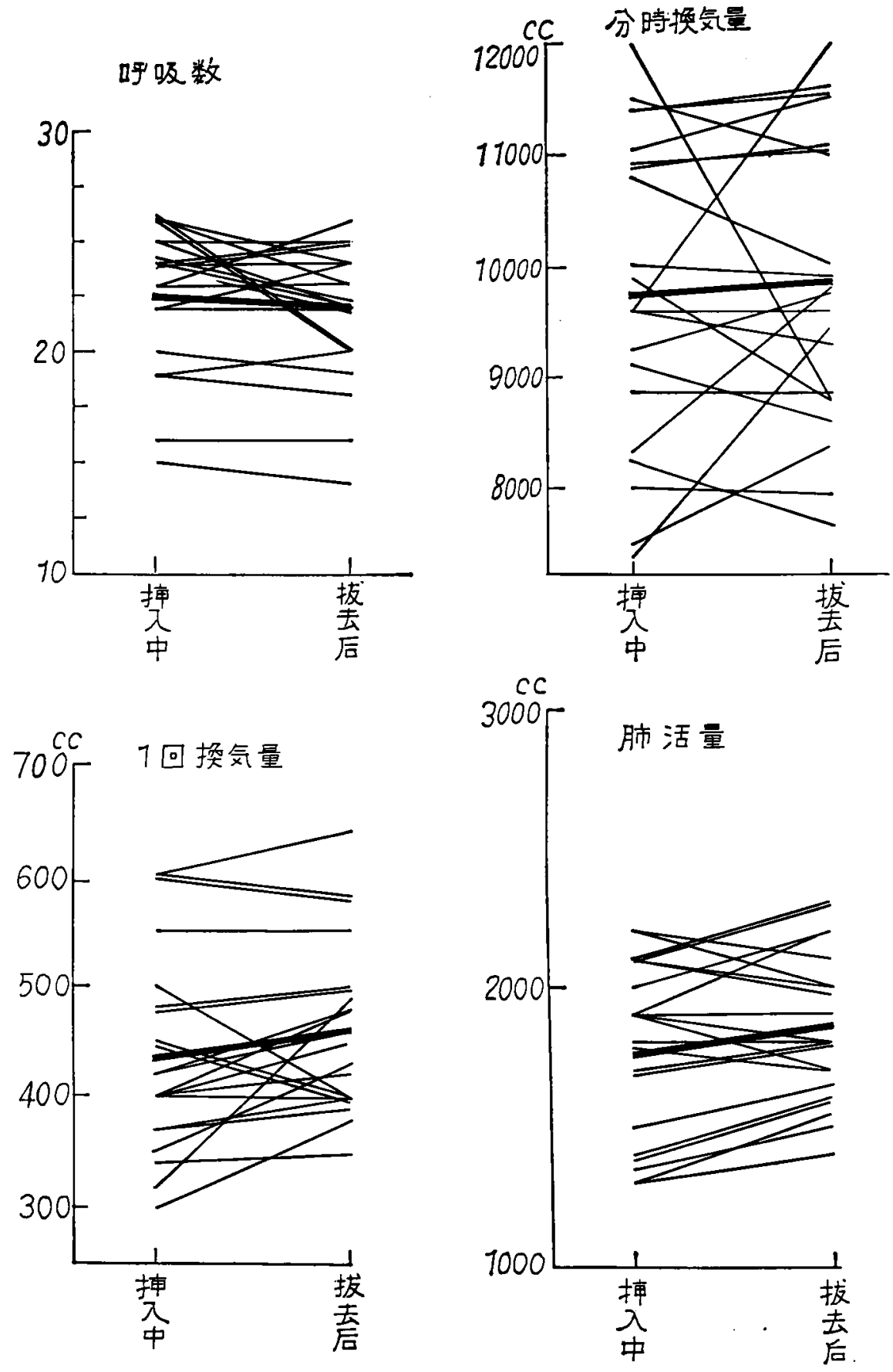

の平均は85.4mmHg (76 100 $\mathrm{mmHg})$ であり,二 重管拔去後 30 分の $\mathrm{Po}_{2}$ 平均は $85 \mathrm{mmHg}(75 \sim 100$ $\mathrm{mmHg}$ ) で二重管の拔去により動脈血 $\mathrm{Po}_{2}$ は平均 $0.4 \mathrm{mmHg}$ 減少した。

$\mathrm{PCO}_{2}$ は二重管抜去により增加は16例，減少は 1 例, 不変 4 例で增加する傾向を示した。二重管㧴入 中の $\mathrm{Pco}_{2}$ の平均は $37.8 \mathrm{mmHg}(34 \sim 42 \mathrm{mmHg}) \tau$ あり，抜去後30分の $\mathrm{Pco}_{2}$ の平均仕 $39.0 \mathrm{mmHg}$ 


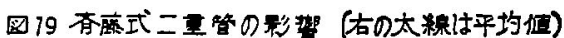

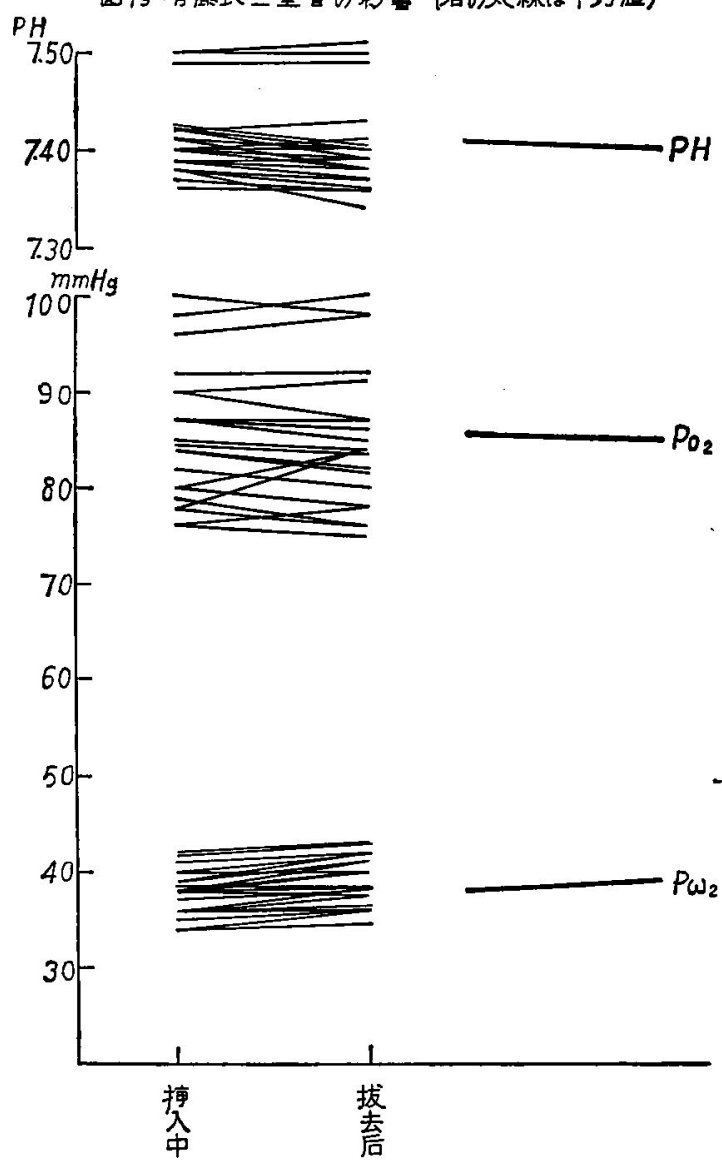

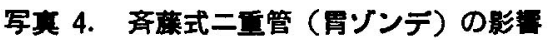
（症例 226 万才胃切除術）

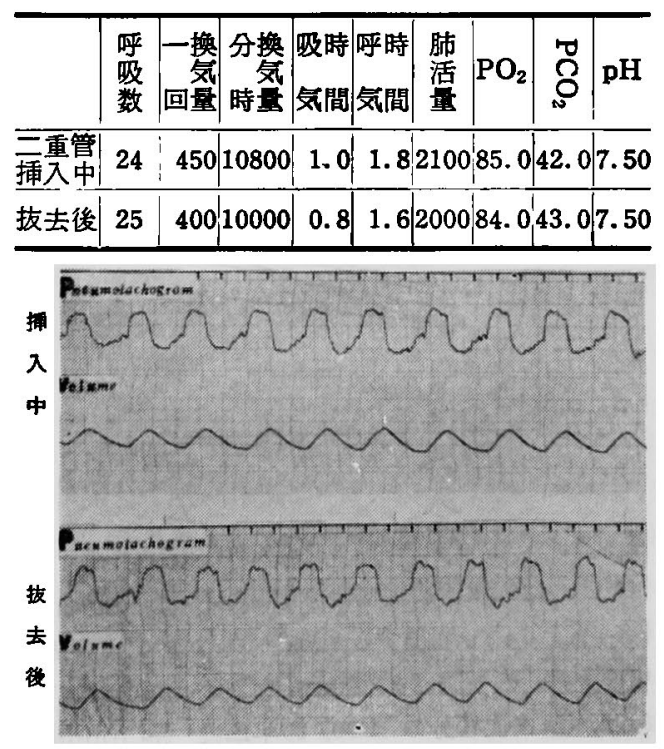

（34.5 43mmHg）で，二重管の抜去により $\mathrm{Pco}_{2}$ は平均 $1.2 \mathrm{mmHg}$ 増加した。

$\mathrm{pH}$ は二重管の抜去により増加は 3 例減少は 13 例, 不㚆 5 例で堿少ずる傾向を示した。二重管㨀入 中の $\mathrm{pH}$ の平均は7.41 (7.36〜7.50) であり, 抜去 後30分の $\mathrm{pH}$ の平均は7.40 (7.34〜7.51) で, 二重 管の抜去により pHは0.01減少した。

\section{3.小括}

手術後第 1 日に斉藤式二重管の挿入してある状態 と抜去後の状態で肺換気機能および動脈血カスス分圧 を比較した（図18，19，写真 4）。短日時の二重管 の㨂入では両者の間に全く有意の差を認め得なかっ た。

すなわち，二重管の抜去により呼吸数は平均毎分 1 回の堿少を, 1 回換気量は平均約20cc の増加を, 分時換気量は平均約 100Ccの増加を, 肺活量は平均 $60 \mathrm{cc}$ の增加を認めた。動脈血 $\mathrm{Po}_{2}$ は平均 $0.4 \mathrm{mmHg}$ の減少, $\mathrm{PCO}_{2}$ は平均 $1.2 \mathrm{mmHg}$ の増加を, $\mathrm{pH}$ は0.01の诚少を認めたが，とれら挿入中および抜去 後の值はすべて正常範囲内にあり，測定誤差範囲に 含まれるものであり，PneumotachogramのP attern は両者の間に殆んど差異を認めなかった。

\section{棇括ならひに考接}

手術後肺合併症は, 胸部, 上腹部手術後に多く発 生し, 手術後の肺換気機能の低下が主な原因として あけ゚られている。4) 6) 31) 36) 37) 38) 39 (40

手術後の低肺換気の問題に最初に着目したのは Churchill および Mc Neil (1952) ${ }^{1) 2}$ で, 手街後 に肺活量を測定し，上腹部手術後では術前の25～30 \%に減少するが，四肢手術では変化がないと述へ， Müller (1929)3) らは上腹部手術後24時間では術前 の 33\%に減少し, Beecher $(1933)^{6)}$ は上腹部手術 後では術前の55\%に, Pooler (1949) ${ }^{411}$ らは35\%に

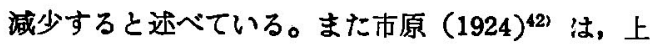
腹部手術後には肺活量は著明に減少することを，石 山 $(1939)^{8}$, 石田 $(1953)^{38}$, 北原, 西邑 (1956) ${ }^{43}$ 三谷 $(1959)^{311}$ らはいずれも手術後に肺活量は減少 し, 上腹部手衔後では下腹部手術後に比しその程度 は大であると報告している。

Comroe (1955) ${ }^{10)}$ によれば肺活量の減少は肺組 織の䋦対的減少のほかに, 肺, 胸壁の拡張不全, 横 隔膜低下の制限，肺の拡張制限などにより若起され るといい，手術後で疼痛による肺，胸碒の拡張制 
していないと述へ，炭酸ガス含量は術直後に減少す ろが，䘗後肺合併症例ではその減少が著明であると 述へ，岸酸ガス含量の減少は手術侵㫫と，衔後肺換 気機能との間に有意の関係があると述へている。永

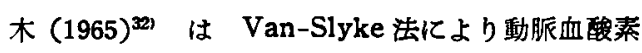
飽和度を測定し，49才以下の症例では総して酸素飽 和度の低下は軽度で, 術後第 1 日目に最低值を示す ものが多く，第 3〜第 5 日に術前值に恢復するが， 50才以上の店例では，術後数日〜 7 日以上にわたっ て85〜90\%の間に低下し很前值にもどるのに相当の 期間を要し，60才以上ではこの傾向が更強いとい い，また，老人の術前後の酸素館和度を 30 例即定 し，術後は低下を認めるが，術後肺合併症の多いと 云われている胆变手術と胃手術を比校しても，その 間に差はなく，下腹部手術（直腸切断衍）と上腹部 手術乞の間にも差はなく，また開胸術と開腹術との 間にも差はなく，術式や手術創の位置によって，術 後低酸素血症の程度に差はみられなかったと述べて いる。益田 $(1965)^{55)}$ は若年者の主として腹激手術 前後の $\mathrm{PCO}_{2}$ を測定し, 術前平均 $38.3 \mathrm{mmHg}$ と正

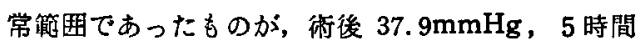
後 $34.7 \mathrm{mmHg}, 24$ 時間後 $33.7 \mathrm{mmHg}$ と減少の傾向 を示したと迟べており，小児老人でも若年者と同様 の傾向を示したと迟べている。Nunn (1962) ${ }^{561}$, Conway (1964) $)^{57)}$ らは動脈血 $\mathrm{PcO}_{2}$ は術後 1 時間 以内に正常值に㪀復するか， $\mathrm{Po}_{2}$ 注胸部 $\mathrm{X}$ 線写真そ の他に異常苍認めない症例でも，街後24時間で正常 值より低下した㱏例の多いことを報告している。

また，術後動脈血 $\mathrm{Po}_{2}$ の低下， $\mathrm{Pco}_{1}$ の上昇に いて, 彼等は肺における Ventilation-Perfusion の不均衡点あげ, Bedican (1963) ${ }^{58)}$, Hamilton $(1964)^{59)}$ らは獄後何等所見なく出現する低酸素血 症は，X線写真上にあらわれないMiliaryatelectasis の Shunting effect によるものであると主張 している。Comroe (1955) ${ }^{101}$ によれば，動脈血酸 素分圧わよび飽和度は，(1)換気不足，(2)掋散障害， (3)静脈動脈閒のシャント, (4)肺血流・換気の不均等 によって低下するといわれ，これら(1)〜(4)の因子は 種々な租合わせで術後に出現し，動眽血 $\mathrm{Po}_{2}$ を低下 させるものと考えられる。

手㝸後の $\mathrm{pH}$ 変動については, $\mathrm{pH}$ の㚆動を最小 限にこどめるように代供機能が働くが，代供性アシ ドーシスの時には代偵機序としての過呼吸がみら れ, Winter (1962) 601 は代供性アンドーシスの顿 復期には $\mathrm{pH}$ 正常かっ, それ以上に高いが, $\mathrm{PCO}_{2}$
は依然低下しているととを指摘し，笹本 $(1962)^{611}$ は換気量の堌加加酸素消量量の增加より大きい場合

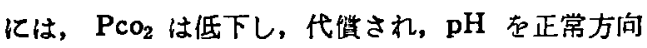
に進めるが，逆の場合は $\mathrm{PCO}_{2}$ は上昇すると述へて いる。街後の代謝性アシドーシスはその原因を柘碎 に求めるものもあるが，多くは手術侵墏によるちの としている。 ${ }^{69163164)}$ Taylor(1950) ${ }^{65)}$, Lindenho-

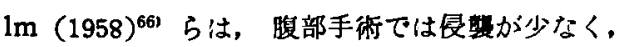
代償性アシドージスを起すととは稀であるといい， 中山 (1965) 54 は食道䠛手術後に $\mathrm{pH}$ を测定し， Winter, 笹本 (1962) ${ }^{67}$ らの述へろところと一致 したと報告している。徒後代謝性アシドーシスの代 供機序としての過乎吸が起り， $\mathrm{PCO}_{2}$ ならびに $\mathrm{pH}$ に対する呼吸中权の感受性の元進が，術後全身状態 の作復とともに換気機能の改善にも影帮をおよばす ためと考えている。益田 $(1965)^{55)}$ は腹部手術後の pH を測定し, $\mathrm{pH}$ は若年者, 老年者ともに術直後 に低下を示し，術後 5 時間で正常籁囲に復するが， 老年者では術直後の低下の程度が強いと述へてい る。

近年老人病学の発展にともない, 手術侵繁の老年 者に及ばす影憵についても斫究が行なわれてきた。 681691 〜31 肺機能についても 74, 75) 76, 77, 78, 791803 老人性 変性を十分考慮する必要があり，てれに加えて他の 疾思による不可逆性変化が残存しているととが多 く，手術の如き負荷を加えられた場合，それに対す る予備力の减少が著明である70181!。諸家の報告をま とめると, 老人肺では組織学的変化として肺胞膜の 萎縮 ${ }^{78}$ ，変性，破壊 ${ }^{791}$ による変化と ${ }^{701}$ ，弾性物貝の 変性による胡の弾性消失と肺組織の線維化が起って くる ${ }^{78) 79}$ 。また老人の肺換気機能については， Richard (1955) ${ }^{791}$, 石田, 䈎本 (1959) ${ }^{821}$ その他多 くの学者によって検索され, 老年に伴ない肺活量, 分時最大換気量, 時間肺活量, 全肺容量等は減 少 し, 残気量は増加するといわれている。著者の調查 成績でる，老人は若年者に比して手術による影整は 大きくHeller (1965) の云う如く $\mathrm{PCO}_{2}$ の增加よ り，むしろ $\mathrm{Po}_{2}$ の低下が著明に認められ，乙の原因 には Microatelectasis が考えられる。

気管支閉塞による無気肺の実験は既に Mendelsohn(1845), Traube (1846) を初めとして多くの研 究が発表されている。宮本 $(1960)^{121}$ は肺葉全体が 無気肺化した場合には，当然換気障害を呈し，正常 のガス交換が妨げられ胡循環系に低酸素血症, 宥酸 ガス蓄積症を惹起するという。無気嘲が 1 肺葉にと 
限は勿諭，鼓腸などのため横隔膜運動は制限され。 横隔膜は高位に固定されるため呼吸運動は横隔膜高 位の水準で行なわれるので，肺活量は当然減少する と考えられる。前述の如く，肺活量のみで肺の換気 機能を論ずるには無理があり，最大換気量の測定は 肺活量以上の意味を有するが46)，被検者のついやす 労力はあまりにも大きく，術後の贯者には不適当で ある。そこで Spirometer を用いて肺の換気機能 を比較的容易に実施しうるものに Tiffeneau test があり，補検者の協力が得やすく，患者の負担が軽 くこの点最大換気量の測定にまさっている。 ${ }^{43}$

最大努力曲楾の分析によって (1)呼吸筋の力, (2) 肺, 胸斯の弾性収縮力, (3)胸酣系の粘性抵执などを 推測することができ，本曲線から得られるデーター のうち最も重要なものは, 肺活量 ( 1 秒量)，1秒 率, M.M.F.である(8)。1秒量を決定する因子に は, 肺弾性収縮力と末佾の気道抵抗とがあり，術後 では肺，胸揢の弾性低下が著明であることから，当 然 1 秒量は減少する。宮本 $(1960)^{12)}$ は時間肺活量 ( 1 秒量)が比最大換気量とほほ比例するととから， 简単に実施し得る1秒量を選ぶべきだと述べてい る。

David (1956) (99) は肺切除街後に 1 秒量は著明に 隇少したと述へ，これは主として胸壁の運動制限に よるものであるといい，林 $(1965)^{50\}}$ は僧幅弁膜应 の術後に時間肺活量 ( 3 秒量) を测定しその城少は 軽度であったと述へている。また永木 $(1965)^{32)}$ は 1 秒量の減少を示す例では気管支病变を伴なうもの が多いと述べている。1 秒率を規定する因子は前述 の肺活量, 1 秒量を規定する因子群の租み合わせで あり， 1 秘量が身長，体重，体表面積と有意の関係 があるのに比して，1秒率はてれらの因子とは全く 関係のない点 ${ }^{13)}$ 48)，外科的諸疾思者について比較検 討するうえに便利である。しかし一方，1秒率は 肺活量，1秒量がともに減少した場合にはあまり変 動しない欠点もあるか，\%v.c. と絽合せれば換気能 力の分類に役立つ ${ }^{511}$ 。永有 ${ }^{321}$ は術前㭘查で 1 秒率が 低下している群では肺合併症が多く発生したが， 1 秒率の減少が特に著しい場合でも，衔後の肺合併应 の発生が増加ずる傾向はみられなかったと述べてい ろ。M.M.F. の価値については Edmund(1955) ${ }^{521}$ は肺機能を知るうえに便利な指標であると述べ，肺 活量, 1 秒量, 最大換気量よりも鋭敏に気道障害を 反映すると述べている。また M.M.F.は時間肺活量 が深吸気位からの最大呼出速度を表わすのに対し
M.M.F. は比較的安静換気を行う際の呼吸基準位に 近い状態での呼出速度をあらわしている。術後に M. M.F.の著減するのは, M.M.F. が肺の粘性抵抗 すなうち気管の構造や变化を表わするのと考えれば 清水 $(1951)^{53)}$ の云う如く，術後の横隔膜の挙上が 肺の構造とくに下葉の杽造に変形をもたらし努力呼 财をしない安静呼吸時の状態ではその影製が強く現 れる結果とみるてとができる。

著者は最大努力性呼気曲線を, 術前, 術後遂日的 に描かせ，年令その他の因子によろ测定值の差違を 除外する意味も含めて, 各術前值を $100 \%$ として, 各手術部位別に比較すると，手術の肺換気機能にお よばす影锌は，胸部手術に最も著明で，上腹部手術 がこれにつぎ，下腹部手術，四肢手術では軽徴であ つた。とれは，手術部位別の比較に年令による因子 が強く影䀺を及ばすのではないかと云うことを検討 するため，年令別の比較（55才以上と40才以下）を 行ってみると, との 2 群の差は手術部位別の差違よ りも明らかに小であり，さらに，これら手術部位別 比較を行う際に，55才以上のいわゆる老人性変化の 現れると考えられている老年層を除外して比較して も，手術部位による差違は明瞭に現れることから， 前述の手術部位各間には, 明らかに差違があると云 うことができる。

肺機能の終局の目的は動脈血の $\mathrm{Po}_{2}, \mathrm{Pco}_{2}$ を正常 に維持することであり, 従来は主として酸素飽和度 についての测定が行なわれてきた。

渡辺 $(1952)^{35 !}$ は, 手術直後に酸素飽和度は最も 低下し，以後恢復に向い，術後 7 日位で術前值に復 帰するのが一般で，炭酸ガス含量は減少するもの と, 増加するものとがあって, 術後肺合并症例では 酸素館和度の著しい低下を認め, その低下の瑅度と 病变肺野の呼吸面制限䈥囲とは一致すると述べてい る。田中 $(1954)^{291}$ は食道瘐手術後の動脈血ガス分 析を行ない，食道全剔例では，術直後，第 1 , 第 2 病日に酸素飽和度低下し，1週間前後で健常值に 復し，炭酸ガス含有量は術直後に術前值よりも低下 し， 1 週間前後で安定するが短期間に発生した機械 的肺機能障害では酸素飽和度は低下し，さらに炭酸 ガス含有量る低下の傾向を示すと述べている。中山 $(1965)^{54)}$ も食道癌手術後には，酸素含量は一様に 低下すろが，肺合併正群ではその低下が著明であ り, 術後 5 日位から術前值をうわまわる程度に恢復 するか⿱，丶 $\mathrm{Po}_{2}$ についてみると，術後 7 日目に烣復 し, 肺合併应発生例では街後14日でも術前值に恢媵 
どまる間は他の肺萧で代僧されるかもしれないが, 1 側肺全体にわたる時には重い偱罢障害を招くが， 胸尉成形例では虚脱が肺の上葉に選択的に加えられ ろために，その結果発生する無気肺る軽るく，肺葉 全体が無気肺化した気胸例に比べてガス交換の障噚 る轻いと云っている。小田 $(1936)^{84}$ は肺虚脱直後 には酸素（vol.\%）は著しく低下し，24時間以後に は濑次增加して術前値に接近するが，正常值えの復 滆には48時間を要し，一方 $\mathrm{CO}_{2}$ は術後 4 時間には増 加少なく，48時間まで增加し以後正常値に恢復する といい, 德毛 $(1940)^{851}$ は気管支を閉塞すると動脈 血酸素合有量は著しく减少するか，炭酸ガスは大差 はくわずか減少するといい，武田 $(1936)^{86)}$ は気管 支結㷊後に動脈血炭酸ガス量は左側主気管支の場合 には直後から減少し，右主気管支の場合には一時增 加した後に減少するといい，また酸素脃和度は左主 気管支結浆では直後より減少し,3時間後に正常值に 復し，右主気管支結絷では著明に減少し，8 時間後 においても40\%の低下を認めたと云う。Lee (1924) ${ }^{871}$ は喀疾による閉堅実験で，X線上 3 時間で肺虚脱

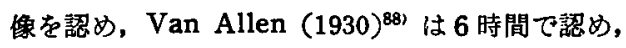
吉田 $(1936)^{89)}$ は24時間に, 1 肺葉全体の無気㬸を 認めたと云い, Coryllos, Birubaum $(1928)^{90}$ 万 は閙塞10分後に肺は著しく容皘を縮少し，6時間後 亿肺虚脱像を認めたと云い，石田 $(1953)^{38)}$ は 6 時 間，12時間，24時間の追求により部分的無気肺が肺 内部より始まり，24時間以内に完全無気肺が完成す ると述へている。

著者は前記の臨床例を検索中に経臨した街後無気 肺例では，X線写真上，明かな無気肺像を認めるの に, その動脈血ガス分圧の変動が他の術後経過良好 例に比し著明な桨動を認めなかったことから犬を用 いて実験を行なったがそれによれば気管支閉塞直後 に $\mathrm{Po}_{2}$ は急激に低下し， $\mathrm{Pco}_{2}$ は上昇し, 以後渐次 饭復の傾向を示し，胸部 X 線写真で肺野に無気肺像 を認める時期には䀣に，動脈血ガス分圧は術前值に 近く饭復を示していた。

Noehren (1958) 910 は $100 \% \mathrm{O}_{2}$ で脯内を固換し た後に気管支を開塞すると，15分で完全無気胡が発 生するが, 䐈内が空気の場合には简笚には吸収され ずその吸収には数時間を要すると述べている。

筆者の $100 \%$ 酸素 15 分間吸入後に気管支を閉塞 （バルーンによる）した犬の実験では, 閉塞後 5 分 後には該当肺野に明らかな䧔影を，10分後には完全 無気肺の像を呈したが，この時期でもなお，右中葉
気管支閉塞例では動脈血 $\mathrm{Po}_{2}$ は低下し恟復の頃向は 認められなかった。

気管支開塞後に急激に低下した $\mathrm{Po}_{2}$ ，上昇した $\mathrm{PcO}_{2}$ の饭復機序は，健康肺による代償性過換気 と, 無気肺領域えの血流量の減少が大いに閔与する ちのと思われるが，無気肺が急激に出現した場合に は，てれらの代供機序のいとますなく，従って動脈 血ガス分圧に著明な変動をきたするのと考えられ ろ。横山 $(1965)^{92}$ によれば, 気道閉塞が起り, 肺 盷内にとじ込められた肺胞気は, その腩胞気内の特 定のガス分圧が混合静眽血中のガス分圧より高い場 合には吸収され，肺胞気中のその成分のガス分圧は 混合静脈血ガス分圧と平衡に達する。空気呼吸時に

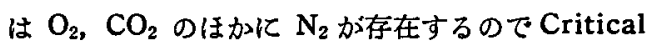
closing condition 亿達することのない限り無気胡 にはならないが, $100 \% \mathrm{O}_{2}$ を吸入している場合には $\mathrm{O}_{2}$ が吸収され，少量の $\mathrm{CO}_{2}$ が血中上り胡胞気中に 排出されるが、, $\mathrm{O}_{2}$ の吸収が著明のため, 閉塞され た肺盷は Critical closing condition となり 算気 肺になるという。吸収による無気肺の速さは $100 \%$ O昅入時では速かで，計算によれば 9.2分位であり 最大呼気位で, 気道閉塞をしだ場合には 3 分間であ るという。 $100 \% \mathrm{O}_{2}$ 吸入中に気管支を閉塞し、レ ントゲンで経過をみていると 5 分以内に肺野の透過 性は低下し急速に虚脱が進行していくのが判ると述 べている。また，Farhi らは動物実験で開胸手術中 では 1 分以内で完全虚脱の起るてとを証明してい る。宮本 $(1960)^{121}$ す述べている如く無気肺が急性 におきた場合には低酸素血症が起るが，無気肺が長 い経過をとって発生した場合には，その部分の換気 は障碍されるが，血管壁の肥厚，㹨少によって血流 量も乏しくなるため強い低酸素血应はみるれないと

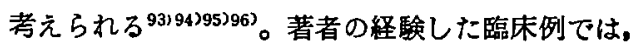
発生までの経過が䌅除であり, 無気肺領域が小範围 であったため，動眽血ガス分圧に著明な変動をきた さなかったものと考えられる。100\% $\mathrm{O}_{2}$ 吸入による 犬を用いた実験により，急性の無気肺発生時には， 胸部 X線所圥と㔚眽血ガス分圧との間にはずれがあ り， $\mathrm{X}$ 線写桌上無気胡像の出現した時期でもなお動 眽血の $\mathrm{Po}_{2}$ は恢復傾向を示していないととが明らか であった。

手術後の肺機能の低下は手桬創の疼痛とてれに伴 なう呼吸制限が主な原因をなしていると考えられる

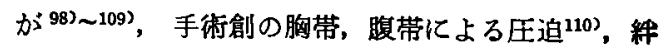
創青または縌帯による手術創の強度の固定, 胸部手 
術後の砂端による圧迫など外力による呼吸制限もま た一つの原因となる。

Moore (1939) ${ }^{111)}$ は腹部の強い圧迫は橫隔膜を上 方に圧排し，胸酣の容積を減少し，肺を圧迫すると 述べており，䒜原 $(1922)^{112}$,'市原 $(1924)^{42)}$ も術後 腹帯による強い圧迫を繁告している。胸部の圧迫は

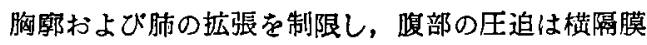

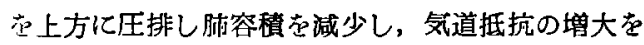
招来する。

健康人に実験的に腹部または胸部を圧迫すると肺 換気機能は低下する。既に報告した如く胸部手術， 上腹部手術後では著明に肺換気は障害されるので, この時期にさらに胸帯, 腹带で強く圧迫するのは低 肪換気の状照やさらに強めることになる。

手街後の疼痛に関して, 疼痛を客観的に知る一つ の方法こして呼吸状態を調べることが古くから行な われてきた。Campiche (1902) ${ }^{113)}$ は手術創の疼痛 と反射的に制限された呼吸運動の関係について暗示 し, Lawen $(1921)^{114)}$ は閏腹手術後に鎮痛剂を持 続的に使用することにより，政後腑合併症の発生を 減少させ得たと報告した。Capelle（1933）100)は 上股部手街後に肺活量を湘定すると，衔後疼痛が現 れないうちは 7〜10\%の减少にすさないが，疼揣が 現れると幐活量は53\%に減少する，こてでモルフィ ンを注射し疼痛を軽減させると肺活量は衔前の $60 \%$ 位に恢復するが，麻酔郕で直接に創の疼痛を除去し てやると肺活量は術前の80\%に恢復したと報告して いる。井上, 多胡 $(1954)^{115)}$ らは, 術後疼㾤により 腑活量は上腹部手術では衍前の $25 \%$ ，下腹部手術て は66\%まで低下したと述べている。手術部位と手術 創の疼痛との関係について西芭 (1956) ‘3) らは胸

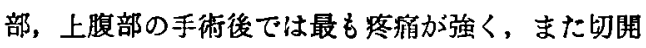
の大きさによっても差があり，多数の神経が切られ れば痛みが強いのは当然であり，㗖部では綐切閒よ り横切開の方が痛みが軽いし，横陽膜呼吸に関係す るはど肺合併症が多いと述べてい。緒方 (1950) 107)も横隔膜に近ければ近い程咳嗽はしたがらない し，呼吸は制限されるので胡合甠定は多く発生する と述べている。

街後に創の疼痛な軽減させる方法として, Capelle $(1932)^{1001}$, Gordon $(1942)^{1011}$, Pooler(1949) 41), Mc Cleary $(1948)^{103)}$, Devidson $(1953)^{116)}$ らは種々の鎮痛剂を用いることにより, 街後胡合併 症を減少させ得たことを述へ，また疼痛を柽減させ ろために，䛧後浅い静かな呼吸さすることが徒後無
気肺発生の大きな原因であると述へている。

手街後には手術創の疼痛のため浅い呼吸となりや すいか⿱，乙の状態は肺換気機能の面からは明らかに 不利であるばかりでなく，気道内に分渻物の䝪溜を きたしやすく拥衍後肺合併症の素地となる。41117 118) 鎮痛剂を適時使用してでるる限り深呼吸を 行なわせるようにすることが大切であるが，鎮 痛剂の使用に際して注意を要するのは程度の差はあ れ，呼吸反射，咳嫩反射の抑制があることてある 119)。

手原後に蹎痛㓮を使用することに対しては Narcotica が好ましから始副作用のため，この使用を 制限し，疼痛に関しては患者自身に説得し，極力か まんさせるべきであると主張する報告もある。106

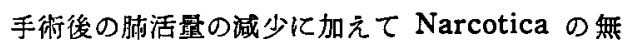
思虑な使用は腑合併症を助長する可能性は大である とする報告もある ${ }^{108)}$ 。佐藤ら (1963) ${ }^{106)}$ は胸部外 科手街後の疼俩を軽恢または消失せしめろために鎮 痛剮を用いることはなるべくさけるか，或は出来る かぎり回数を少なくすることが望ましく，それは術 後呼吸が疼痛や手術をのものによって抑制されてい ろので， ミのうえ，呼吸卯制が加わると危険である からと述へている。Narcotica の使用の可非ある いは使用量についてもなお論誡されているが著者の 検索では Narcotica の使用は肺換気機能の効率を 改善し，動脈血ガス分圧に与える影響も函めてわず かな正常範囲内での変動であり，鎮痛剤の注射が動 脈血ガス分圧に悪影響を及はしているとは考えられ ず，Narcotica の使用を極度に制限するのは逆効果 であり，患者の状態を十分観察したうえで鎮痛に留 意すべきであると考える。また鎮痛剂の使用によ り，手術創の疼痛を除去するととか，強制的に咳濑 を十分行なわしめる一つの方法で, 術後肺合併症予 防の一手段であると考える。著者らはかって，鎮痛 剂を使用したのちに Radigan $(1960)^{1202}$ の方法を 改良した plastic tube tracheostomy ${ }^{121) を}$ 肺合併症の発生を減少しえたととを報告した。

消化管手琎後に経奥的に挿入する胃ソンデは日常 臨床上よく用いられる。筆者の教室では斉藤教授創 案 ${ }^{122)}$ の斎藤式二重管を経鼾的に挿入し，外管は胃 内容る持続吸引し，内管は栄養補給用としてroutin に使用している。

胃ソンンデの呼吸機能におよばす影䅉について Be$\operatorname{van}(1961)^{123)}$ はチューブを抜去すると呼気量を 4 〜24\%改善し, チューブの插入が呼吸上咳嫩の両面 
に悪影䒜を及はしていると述べ, Le Winn(1962)

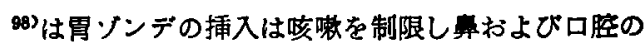
分泌物と気管内に流入させるととから，術後合併应 の発生を多くすると述へている。Mackayは24例に ついて観察を行ないチューブの挿入は最大呼気量お 上び肺活量とは無関係であると報告している。

永木 $(1965)^{322}$ は胃ソンデの挿入期間中，他の症 例と比較し、酸素飽和度に差は認めなかったと述 べ, 術後 1 週間以上捙入した例です酸素飽和度の低 下はみられず,胃ソンデの㨉入自体が街後の低酸素 血症の発現におよばす影響は認められなかったと述

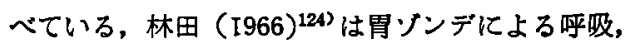
咳濑の抑制，诶頭の刺戟と感染などを考えると，胃 ソンデを長期間使用するてとは得策でないと述べと くに胃ゾンデを 5 日間以上使用したものでは肺合并 症の発生が急激に増加すると述へておう，田中(196 6) ${ }^{125)}$ も老人外科にかける胃ゾンデの使用に注目し 挿入が 4 日間以上にわたると悪影暃があると述べて いる。また三谷 $(1958)^{31)}$ は胃切除街後の肺合并症 について調查し, 胃ソンデの挿入が術後肺合併症の 発生に関係があると述へている。筆者の教室で使 用している吝藤式二重管は術後 2 日ないし 3 日の留 埴が最も多いので筆者は短期間の胃ソンデの使用が 肺機能におよぼす影響について調べ, 肺換気機能, 動脈血ガス分压にはとんど障害は認められなかっ た。胃ソンデを長期間使用の場合には，胃ゾンデを 長期間使用しなければならなかった病態そのものの 肺機能に与える影䈉て考虑すべきで，必要な場合に は樯躇するととなく，進んで行なうべき方法と考 える。

桔論

外科的諸疾思において，各手術部位別に䐈換気機 能 (肺活量, 1 秒量, M.M.F.， I 秒率) および動 脈血 $\mathrm{Po}_{2}, \mathrm{Pco}_{2}, \mathrm{pH}$ 老術前汃徒後にわたり湘 定しその烣復までの過程を梌索した。また前記の 臨床例観察中に経験した街後無気胡洌ではX線写真 上明らかな無気胡を認めるにもかかわらず，二の動 眽血ガス分圧の変動が，他の術後䅅過良好例に比へ て著しい変動を認めなかったてとから，犬る用いて 実験的に無気肺発生時における動脈血ガス分圧と X 線所見との関連を検した。

1)：肺換気機能と密接な関係のある胸部舟患では 術前すでに腩換気機能の低下を示し，上腹部疾患 でも軽度の低下を認めるが、下腹部, 四肢疾患で は殆んど正常值さ示していた。
2）：手術後肺活量，1 秒量，M.M.F.，1秒率の 変動は，各手術部位とも同一㑯向を示している

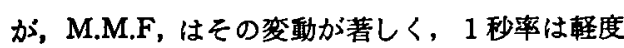
であった。肺換気機能は，手衙後当日は例外なく 低下するが，胸部手術が最も著明で，上腹部手 術, 下腹部手術がこれて続き，四肢手術は最る軽 度であった。衍後 2 日から坂復に向かい, 街後 7 日においても胸部手術, 上腹部手街は術前值に復 していないが、下腹部手術，四肢手誉術では術前 值䇺囲に欧復している。

3）: 胃切除衍之由垂切除術の肺換気機能におよは す影辢を比較すると，圈切除術は術後当日に低下 は著しく，その㤆復は遅延しているのにたいし中 垂切除術は軽度であった。

4) : 手術後の動脈血の $\mathrm{Po}_{2}, \mathrm{Pco}_{2}, \mathrm{pH}$ の変動: 各手術部位とも同一傾向を示し，Po $\mathrm{Po}_{2}$ 街後当日 〜術後 1 日に著しく減少し, 胸部手術が最も著明 で，上腹部手術，下腹部手術がてれにつぎ，四肢 手術が最も軽度であった。術後 3 日から恢復し， 術後 7 日には胸部手術, 上腹部手術ではなお術前 值に復していないが，下腹部手術，四肢手術では 術前值に復している。 $\mathrm{PcO}_{2}$ は術当日〜街後 1 日 に增加し，胸部手術に著明で，他の手術部位間に は有意の差はない。術後 3 日〜術後 5 日には術前 值に復している。 $\mathrm{pH}$ 江術後当日〜術後1日に低 下し, 胸部手術に著明で衍後 3 日〜 5 日に正常值 に復している。

5) : 胃切除術と虫垂切除術の動眽血 $\mathrm{Po}_{2}, \mathrm{PcO}_{2}$, $\mathrm{pH}$ におよはすす影響を比較すると, 胃切除術は街 後の変動が強く，その饭復は遅延する。

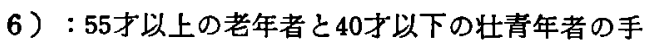
衍前後の肺換気機能を此較すると, (腩活量, 1 秒率）老年者に術後低下が認められ，術後 7 日で もなお術前值に缺復していない。

7）:また55才以上の老年者と 40 才以下の壮青年者 の手術前後の動脈血 $\mathrm{Po}_{2}, \mathrm{PcO}_{2}, \mathrm{pH}$ を比較す ると老年者にその影锌仙強く、特に $\mathrm{Po}_{2}$ 低下が著 明であった。 $\mathrm{Pco}_{2}, \mathrm{pH}$ 亿はみるべき差異は認め られなかった。

8) : 実験的に犬の右中葉気管支を秸禁閉塞した例 では動脈血 $\mathrm{Po}_{2}, \mathrm{PCO}_{2}, \quad \mathrm{pH}$ 先閉塞直後に $\mathrm{Po}_{2}$ は著明に減少し， $\mathrm{PCO}_{2}$ は増加し $\mathrm{pH}$ は低下する 傾向を示しこの恢復には48時間を要した。バルー ンによる気管支閉塞で右下炗気管支閉塞では $\mathrm{Po}_{2}$ は閉塞直後より著明に减少し, 閉塞後 2 時䦎位で 
饮復に向加い， $\mathrm{Pco}_{2}$ は閉塞直後増加するが閉坓 後30分位で烣復する。閉塞後 7 時間までの胸部 $\mathrm{X}$ 楾写真の追跡では，無気肺像を認めなかったが, この時期までには既に動脈血ガス分圧は閉塞前值 に近く恢復していた。

9）: 100\% 酸素10分間吸入直後に，バルーンによ ろ気管支閉塞では，右中部気管支閉塞 例では， $\mathrm{Po}_{2}$ は閉塞直後より著明に低下し，閉塞後10分で は，訨然低值を示し㪀復傾向はみられない。右末 梢気管支閉塞例では， $\mathrm{Po}_{2}$ は直後より著明に低下 するが，開塞後10分では咴復傾向が認められるも のもある。胸部X線写真上無気肺像の出現は閉塞 後 $5 \sim$ [0分で, との時期では $\mathrm{Po}_{2}$ は低下し，開塞 前值に烣復していない。

10）前記実験成積汃ら, 無気肺発生が臨床上明らか にされた時，すなわちX線写真上無気肺像を明ら かに認めた時において，低酸素血症の認められな い事実について解明した。

11）：健康人のに腹部を圧迫すると呼吸数は増加 し， 1 回換気量は減少し，分時換気量には殆んど 変動なく肺活量は正常時の91\%に诚少した。胸部 圧迫では，呼数吸は腹部圧迫時よりさらに増加し 1 回換気量法減少し分時換気量は增加の㑯向を示 し, 肺活量は正常時の85\%に減少した。すなわち 胸部の単独圧迫は腹部圧迫よりその影響は著明で あった。腹部胸部同時圧追では，呼吸数は前 2 者 に比べ著明に增加し，1 回換気量は減少，分時換 気量に著変なく，肺活量は正常時の74\%に堿少し た。しかしPneumotachogram の Pattern の変 化は軽度であった。

12）: 術後, 手術創の疼痛時には, 吸気時間, 呼気 時間とともに短縮し，1回換気量は減少する，分 時換気量は増加し, 肺活量は減少の傾向を示し た。 $\mathrm{Po}_{2}$ は增加し, $\mathrm{Pco}_{2}$ は低下， $\mathrm{pH}$ は上昇の 傾向を示すが, Narcotica 注射による鎮痛時に は, 呼吸数は娍少し吸気時間, 呼気時間は延長 し, 1 回換気量は増加し, 分時換気量は減少し, 肺活量は増加の傾向を示した。 $\mathrm{Po}_{2}$ は诚少， $\mathrm{Pc}$ $\mathrm{o}_{2}$ は增加，pHは低下したがてれは病的なるので はない。Pneumotachogramの Pattern には著 変なく, 疼痛時には胸暨運動の抑制, 鎮痛時には 抑制が解除された。

13）：胃切除術およひ䏣のう摘出術について術後第 1 日斉藤式二重管の留置時の状態と抜去後の状態 で肺換気機能および動脈血ガス分圧とを比較した
結果，二重管抜去により呼吸数はわずか減少し， 1 回換気量は增加, 分時換気量と肺活量はわずわ に增加した。動脈血 $\mathrm{Po}_{2}$ は減少, $\mathrm{Pco}_{2}$ は増加, $\mathrm{pH}$ は減少したか⿱，插入中と掖去後の間には有意 の差はなく、二重管の括入が肺換気機能，動脈血 ガス分圧に悪結果を及はしているとは考えられな い。抜去により我か 好転するものでもない。ま た両者の間に Pneumotachogram の Pattern には変化は認められなかった。

稿を終るに臨み，終始御想切なる御指導と御校閲 をたまわった恩師斉藤 添教授に心から感謝の意を 表します。

また種々御助言下さいました広尾病院第 3内科医

長 長岡㴊博士に感謝いたします。

\section{参考 文献}

1) Churchill, E. D.. Pulmonary atelectasis with especial reference to massive collapse of the lung, Arch. Surg. 11 (4), 489, 1925.

2) Churchill, E. D., Mc Neil. D.,

The reduction in vital capacity following operation. Surg. Gyn. Obst. $44: 483 \sim 488$, 1927.

3) Müller, G. P., Overholt, R. H., Pendergross, E. P., Postoperative pulmonary hyperventilation, Arch. Surg. $19: 1322 \sim 1345$, 1929.

4) Powers, J. H., Vital capacity : its significance in relation to postoperative pulmonary Complications, Arch. Surg. $17: 304 \sim$ 323, 1928.

5) Scott, W. J. M.. Cutler, E. C., Postoperative, massive Atelectasis, J. A. M. A. 90 : 1759, 1928.

6) Beecher, H, K., Effect of laparotomy on lung volume : Demonstration on newtype of pulmonary Collapse. J. Clin. Invest. 12 : 651, 1933.

7) 河合直次：腹部手術創の疼痛に対する処蹧。 臨床医学, $24: 26,1936$.

8）石山福次郎：急性肺虚脱, 日外会誌, 39 : $1333 \sim 1520,1939$.

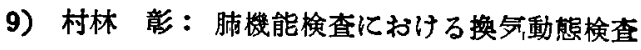
の価值について, 日胸外会誌, $11: 133,1963$. 
10) Comroe, J. H. et al., The lung, Year book publishers 1955.（村尾誠訳 医莐薬出版 1956）

11）䉀本 浩, 横山西朗：換気機能障害の評価, 呼吸と循㻴， $6: 459,1958$.

12）宮本 忍：胸部外科の病態生理, 克誠堂, 東 京, 1960.

13）中村 隆，哱島 任.・肺機能とその臨床，文光 堂, 東京, 1960.

14）松田幸次郎：医学の動向28集；肺機能検査の理 論之実際，金原出版，東京，1961.

15）笹本 浩, 横山暂朗：スパイログラムの臨床 (換気機能の検查法とこの評価), 医学書院, 東 京, 1959.

16) 村尾 誠：肺機能検查について, 日胸, 23 : $321,1964$.

17）石田尚之：小児胸部外科と胡機能, 胸部外科, $18: 446,1965$.

18）中村 隆，滰沢敬夫，笹本 浩: 現代内科大系 呼吸器疾思 ( I ), 中山書店, 東京, 1965.

19）長浜文雄, 山中㣚之, 片岡紀夫：脯機能検查, 綜合臨床, $14: 270,1965$.

20）佐川弥之助, 久野健志: 肺機能検查法 (肺外科 にわけろ術前検査を中心として, 胸部外科, $18: 219,1965$.

21）金上晴夫：肺手術を目的とした肺機能梌查，胸 部外科, $18: 6,1965$.

22）城所達士 : 低肺機能症例の取り扱い方につい $\tau$, 外科治療, $14: 595,1966$.

23）中村 隆，金野公郎：呼吸機能，綜合臨床， $15: 996,1966$.

24）頴原 寛：動脈管閒在店の手術前後における心 肺機能, 日胸外会誌, $14: 130,1966$.

25）篗本 浩, 横山哲朗 : 分時最大換気量, 呼吸之 循㻴, $6: 11,1958$.

26）田中康雄：食道癌手術前後の動脈血々波ガス分 析, 千大医学会誌, $30: 640,1954$.

30）渡辺 昭：胸部食道癌手郝後の肺合併症に関す 万研究, 日胸外会誌, 58：1031 1042，1957.

31）三谷潯美：術前肺機能からみた胃切除術後肺合 并症の検討, 日胸外会誌，60:254，1959.

32）永木久允：老人外科注ける原前後の呼吸器お

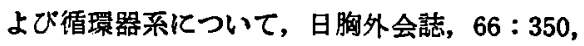
1965.

33）清水 勝, 深攧一男: 生理学用ガス分析計, 分 析機器, $2: 58,1964$.
34）森川長：外科疾患及びてれらに対する手街的 骎隻の 血液ガスに及ばす影響，東京医会誌， $55: 75,1941$.

35 : 渡辺千春: 街後肺合併症の研究, 日胸外会誌, $53: 205,1952$.

36) Stringer, $P$.. Atelectasis after partial gastrectomy, Lancet 252, 289, 1947.

37) Mempriss., T, W., Estheridge, F. G., Postoperative chest Complication in Gastric Surgery, Brit. Med. J, 2 : 466, 1944.

37) 石田正統：街後肺合併症の研究, 日外会誌, $54: 713,1953,54: 835,1953,54: 911,1954$.

39) Kurzweg, F. T., Pulmonary Complications following upper adominal surgery, Amer. Surg. $19: 967,1953$.

40) Patey, D. H., The effect of abdominal operations on the mechanism of respiration, Brit. J. Surg. $17: 487,1930$.

41) Pooler, H. E., Relief of Postoperative pain and its influence on vital capacity. Brit.

J. Med. $2: 1200,1949$.

42）市原 厥：手術後特に開腹術後の肺合併症, 日 外会誌, $24: 176,1924$.

43）北原暂夫, 西邑信男他：術後疼痛の除去につい $\tau$, 手術, $12: 488,1956$.

44）西邑信男, 桑原 稔: 術後の疼痛之镍痛法。外 科治療, $7: 103,1962$.

45）西邑信男，森岡 亨：鎮痛鎖静剂並びに麻醉 刘, 診断と治療, $52: 47,1994$.

46）中村 隆，滰島 任・低肺機能者の診断，麻々 心, $9: 87,1962$.

47）金上晴夫：䐉手術を目的とした腩機能検查，胸 部外科, $18: 371,1965$.

48）中村 隆，滝島 任：機能検查のえらび方，よ み方, 呼吸機能, 綜合臨床, $15: 996,1966$.

46) David, V. P., Progressive changes in ventilation following pulmonary resection. Surg. Gyn Obst. $103: 455,1956$.

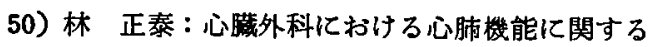
臨床的研究, 日胸外会誌, $13: 376,1965$.

51）滝島 任: 第15回日本結核病学会東北地方会, 1957.

52) Edmund, C. L., Ward, S. F., Maximal midexpiratory flow, Amer. Rev. Tub. 72. $783,1955$. 
53）清水散男：人工気腹療法に関する研究, 結核, $26: 589,1951$.

54）中山隆市：血液ガス，酸塩基平衡よりみた食道 㴼徒後の肺合併应と炭酸ガス吸入に関する臨床 的研究, 日胸外会誌, $13: 166,1965$.

55）益田貞彦：外科領域にわまる酸塩基平衡に関す 万研究，特に老人外科る中心として，日外会 誌, $66: 1772,1965$.

56) Nunn, J. F., Hypoxemia after general anesthesia, Lancet, $7257: 631,1962$.

57) Conway, C. M., Payne. J. P., Hypoxemie associated with anesthesia and controlled respiration. Lancet $7323: 12,1964$.

58) Bendican et al., Impaired Oxygenation in surgical patients during general anesthesia with controlled ventilation a concept of atelectasis. New Engl. Med. 269 : 991, 1963.

59) Hamilton, W. K., McDonald, J. S., Fischer, H. W.. Postoperative respiratory Complications A Comparison of arterial gas tensions, Radiographs ad physical examination. Anesthesiol, $25: 607,1964$.

60) Winter, R. W., Dell, R. B., Clinical physiology of metabolic acidosis, Postgraduate Med. 31 : 161, 1962.

61) 笹本 浩: 吸呼吸性アシドージスの管理, 呼吸 と循環，10:467, 1962.

62) Schweizer, O., Howland, W. S., Disturbance in Acıd-Base balance During Major. Surgery, Anesthesiology. 24 : 158, 1963.

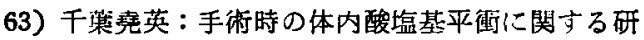
究, 兵庫県立医大紀要, $2: 3 \sim 4,1951$.

64）笹本 浩：血液炭酸ガス分圧よりみたる心肺性 動態, 日偱器学会, $18: 132,1954$.

65) Taylor, F. H., Roos, A., Disturbance of acid-base bealance during ether Anesthesia with special reference to changes Occuring during thoracic surgery, J. Thor. Surg. $20: 285,1950$.

66) Linderholm, H., Norlander. O, Carbondioxide tension and bicarbonate Content of Arterial blood in relation to anesthesia and Surgery. Acta. Anesth Scand, $2: 1$, 1958.
67）笹本 浩, 横山辇朗：呼吸性アシドージスの管 理とくに $\mathrm{CO}_{2}$ 中毒症侯群の治療を中心として 呼吸と循環, $104: 467,1962$.

68）稲本 晃, 兵頭正義：老人の麻䣲，外科治療, $8: 173,1963$.

69）稲本 晃, 武下 洗: 老人の術前, 術後の管 理, 外科診㫫, $8: 135,1966$.

70）卜部美代志他：老年者外科における問題点，外 科治療, $8: 182,1963$.

71）山岸三木雄他：老年者の術後管理について，外 科治療, $8: 195,1963$.

72）林 四郎：老人の術後生体反応, 外科治療, 8 : 200, 1963.

83）石川七郎 : 老人に於ける胸部の手術, 主に肺 癌の手術について, 外科診療, 8:151, 1966.

74）山村秀夫 : 老年者の麻酔, 老年病, 4:110, 1960.

75) Cutler. C. W., Surgical indications and Suugical management in the aged. Newyork J. Med. $55: 489$, 1955.

76) Fromer, J. L., Surgical risk of the elderly asthematic. Surg. Clin North. Amer. 34 : $627,1954$.

77) 石田二郎：老年者の呼吸器, 老年病, $4: 207$, 1960.

78) Azguy. et al., : Amer. int. mud. $57: 1,1962$

79) Richards. D. W., Cecil and Loebs medicine 9 the 1053, 1955.

80) Norris. A., Changes in ventilation with age. aging of the lung, Grune and Stratton 136, 1964.

81）杉山浩太郎：他老人の肺機能, 日胸，23： $21,1964$.

82）石田二郎：高年者の肺機能に関する研究, 日本 医事新報, 1824，21：1959.

83) Heller, M. L., Watson, T. R., Postoperative hypoxemie and its treatment with nasal oxygen : Polarographic study. Surg. 58 : 819, 1965.

84）小田源太郎：実鍳的充実性肺虚脱に関する研 究, 日外会誌, $37: 672,1936,38: 596,689$, 807, 1937.

85）徳毛卓三：肺循環ならびに血液ガスよりみたる 肺機能に関す万研究，日外会誌，41:1091。 1940, $41: 1474,1941$. 
86）武田義章，池田浩蔵：実験的急性広沉性然気肺 の研究, 大阪医事新誌, 35:113，1936.

87) Lee. W. E., Tucker, G., Ravdiu, I. S., Experimental atelectasis, Arch. Surg. 18 : $242,1929$.

Lee, W. E., Postopesative Pulmonary Complications. Aun. Surg, $79:$ 506, 1924.

Lee, W. E., Studies on experimental pulmonary atelectasis. Aun. Surg. $88: 15$, 1928.

88) Van Allen, C. M., Adames, W. E., The mechanism of obstructive pulmonary atelectasis, Surg. Gyn. Obst. $50: 385,1930$.

89）吉田伸次：完全閉塞性気管支異物並にその異物 摘出後の治療に関する実験的研究，福岡医大誌 $29: 1819,1936$.

90) Coryllos, P. N., Birnbaum, G. L., Studies in pulmonary gas absorption in bronchial obstruction, Amer. J. Med. Scie. 183 : 317, 1932.

91) Noehren, T. H., Intermittent positive pressure breathing (I.P.P.B./I) for the prevention and management of postoperative pulmonary complications, Surg, $43: 658$. 1958.

92) 槛山晢朗：無気胡発生のメカニズム，呼吸と循 環, 13, 1965.

93) Peters, R. M., Roos, A., The effect of atelectasis on pulmonary blood flow in the dog, The thoracic Surg, $24: 389,1952$.

94) Peters, R. M., Benson, W .R.. The effect of prolonged atelectasis or ischemia upon the lungs of growing dogs. J. Thorac. and Cardiovascul. Surg. $49: 179,1965$.

95) Long, E. T., Adames, W. E., Benfield, J.R., altered hemodynamics in the pulmonary circuletion following resection of an atelectic lung, J. thorac. Cardiovascul Surg. $40: 640,1960$.

96) Peters, R. M., Loring, W. E., Sprunt, W. H. J.R.An experimental study an the effect of chronic atelectasis on pulmonary and $\mathbf{b}$ ronchial blood flow, Circulation Res. 7 : $31,1959$.

97）来須正男，松繁 薄，伊庭利治：1側気管支閉
塞が肺ガス交换，血液ガス特に雨側肺個別流血 量に及ばす影蚝について，京都府医大誌，23 : 905, 1938.

98) Le Winn, E. B. and Greenstein, S.. Postoperative medical evalution of the respiratory system, Arch. Suzg. $84: 277,1962$.

99) Capelle, W., Arch. f. klin. Chir. Bd. 177 : 1933.

100) Capelle. W.. Die Bedeutung des Wundschmerzes und seiner Ausschaltung für den ablauf der atmung bei Laparotomiesten. Detsch. Z. Chir. 246, 466, 1935.

101) Gordon, E. D., Canad. Med. Assoc. J. 49 : 478, 1943.

102) Kraft. Canad. Med. Assoc. J. 57 : 350 , 1947.

103) Mc Cleary, R. S., Zollinger, R., Lenahan. N. E.. The Clinical study of the effect of intercostal nerve block with Nupercain in oil following upper abdominal Surgery.

Surg. Gyn. Obst. 86 : 680, 1948.

104) Campbell, S. M., Gordon, R. A.. Canad. Med. Assoc. J. 46 : 347, 1942.

105) Hewer. C., recent advances in anesthesia and analgesia. 6th Ed. London, 1948.

106）佐藤陸平, 石田博厚：胸部外科手衡後の疼痛 の対策, 外科治療, $7: 1,1962$.

107）緒方富雄：手術後の痛み，䀢学のあいみ，10 : 86, 1950 .

108）大井 実：腹部手術後の疼痛, 治療, 38 : 292, 1956.

109) King, D. S., Postoperative pulmonary complications, Surg. Gyn. Obst, $56: 43$, 1933.

110) Rudy, N. E.. et. al., role of intermittent positive pressure breathing postoperatively. J. A. M. A. $167:$ 1093, 1958.

111) More, A. E., Treatment of Postoperative Atelectasis, Surg. $5: 420,1939$.

112）萩原義雄：手術後肺合併症, 日外会誌, 23 ： 565, 1922.

113) Campiche, P., Brit. J. Anesth. $33: 628$, 1961.

114) Halmagyi, H., Weis, K. H., Buchwald, C, Veränderungen der Atemfunktion durch 
operationen im Bereich des oberbauches, der Chir., $34: 481,1963$.

115）井上権次, 多胡金三：術後疼痛除去に関する 研究, 日臨外, $15: 20,1954$.

116) Davidson, J., Prevention of postoperative chert complications. Lancet $1: 1225 \sim 1226$, 1953.

117) Jones, J. C., Prevention and treatment of postoperative pulmonary Complication. Surg. Clin. North Amer. $34: 619,1954$.

118) Lassen, H. K., The influence of various operations and of postoperative complications on vital capaccity, Acta. Chir. Scand. $81: 361,1938$.

119) Weber, J. C. P., Morphine and Amyphena zole for postoperative analgesia following mager thoracic Surgery, J. Thorac. Surg.
35 : 105, 1958.

120) Radigan, R. L., King. R. D., a techNique for the prevention of postopesative Atelectasis. Sur. $47: 184,1960$.

121）片岡一朗，盤江弘之：術後肺合并症の予防 法, 臨床外, $17: 1149,1962$.

122）斉藤 淏，長島敬助：胃手術後早期における イレウスの診断と治療 (吸引兼補給管の応用) 外科, $22: 113,1960$.

123) Bevan, P. G., Factors affecting respiratory capacity in patient undergoing abdominal Surgery. Brit. J. Surg. 214 : 126, 1961.

124）林田健男, 赤沢章嘉：老人における胃, 十二 指腸の手術, 外科診療, $8: 164,1966$.

125）田中大平：老人外科の問題点, 日臨外医会 誌, $27: 23,1966$.

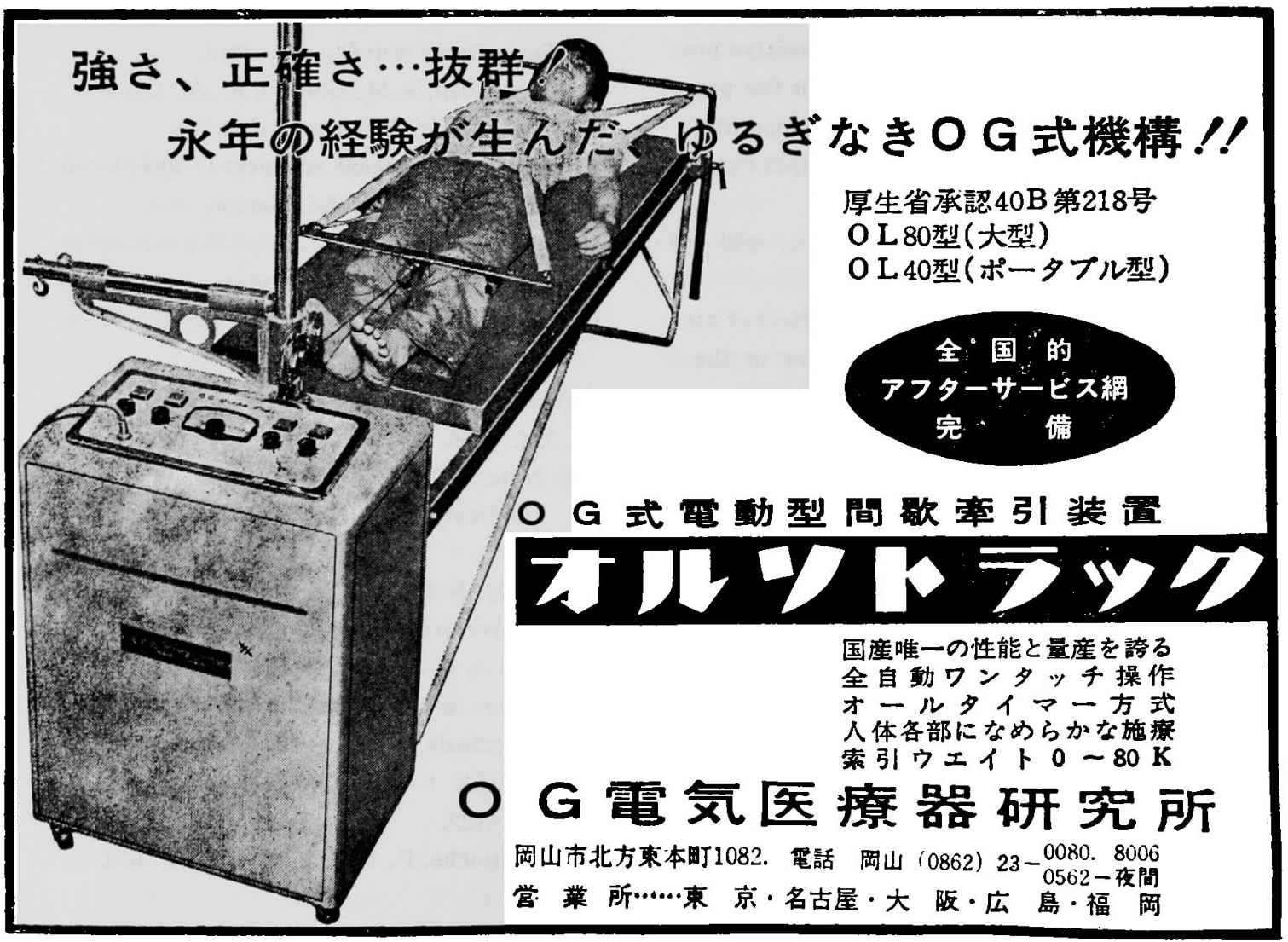

